\title{
Albumin metabolism and aging
}

Citation for published version (APA):

Horbach, G. J. M. J. (1986). Albumin metabolism and aging. [Doctoral Thesis, Maastricht University]. Rijksuniversiteit Limburg. https://doi.org/10.26481/dis.19861017gh

Document status and date:

Published: 01/01/1986

DOI:

10.26481/dis.19861017gh

Document Version:

Publisher's PDF, also known as Version of record

\section{Please check the document version of this publication:}

- A submitted manuscript is the version of the article upon submission and before peer-review. There can be important differences between the submitted version and the official published version of record.

People interested in the research are advised to contact the author for the final version of the publication, or visit the DOI to the publisher's website.

- The final author version and the galley proof are versions of the publication after peer review.

- The final published version features the final layout of the paper including the volume, issue and page numbers.

Link to publication

\footnotetext{
General rights rights.

- You may freely distribute the URL identifying the publication in the public portal. please follow below link for the End User Agreement:

www.umlib.nl/taverne-license

Take down policy

If you believe that this document breaches copyright please contact us at:

repository@maastrichtuniversity.nl

providing details and we will investigate your claim.
}

Copyright and moral rights for the publications made accessible in the public portal are retained by the authors and/or other copyright owners and it is a condition of accessing publications that users recognise and abide by the legal requirements associated with these

- Users may download and print one copy of any publication from the public portal for the purpose of private study or research.

- You may not further distribute the material or use it for any profit-making activity or commercial gain

If the publication is distributed under the terms of Article $25 \mathrm{fa}$ of the Dutch Copyright Act, indicated by the "Taverne" license above, 
ALBUMIN METABOLISM AND AGING

J.H. Pasmans Offsetdrukkerij B.V., 's-Gravenhage 
C.IP

ISBN $90-9001394-6$

This thesis is available as a publication of the Institute for Experimentall Gerontology of the Division for Health Research TNO, Rijswijk, The Netherlands 


\section{ALBUMIN METABOLISM AND AGING}

\section{PROEFSCHRIFT}

ter verkrijging van de graad van doctor in de Geneeskunde aan de Rijksuniversiteit Limburg te Maastricht, op gezag van de Rector Magnificus, Prof.Dr. F.I.M. Bonke, volgens het besluit van het College van Dekanen, in het openbaar te verdedigen op 17 oktober 1986, om 16.00 uur.

door

Gerard Joseph Maria Jean Horbach

geboren op 18 mei 1957

te Heerlen 
PROMOTOR: $\quad$ PROF.DR. C.F. HOLLANDER

CO-PROMOTORES: DR. C.F.A. VAN BEZOOIJEN

DR. S.H. YAP

REFERENTEN: PROF.DR. R. CHARLES

PROF.DR. J.A. FLENDRIG 
Aan mijn ouders

The work described in this thesis has been performed at the Institute for Experimental Gerontology of the Division for Health Research TNO, Rijswijk. The Netherlands 

Men kan nooit een definitieve verdediging geven van wat men doet. Alleen maar een verdediging met betrekking tot iets anders, dat is vastgesteld. Dat wil zeggen, dat men geen andere reden kan aangeven, waarom men zo moet handelen (of heeft moeten handelen), dan dat daardoor deze situatie, die men weer als doel moet aanvaarden, zal ontstaan. 


\section{TABLE OF CONTENTS}

I GENERAL INTRODUCTION

1-1. AGE-RELATED CHANGES IN PROTEIN SYNTHESIS IN RODENT LIVER

1-1a. General aspects of protein symthesis with age 18

1-1b. Age-related changes in RNA synthesis and mRNA levels

1-1c. The influence of the components of the translational apparatus on the changes in protein synthesis with age

$1-1 d$. Possible sources of differences in experimental results

1-2. THE INFLUENCE OF AGE ON PROTEIN ELIMINATION PROCESSES

1-3. BIOCHEMISTRY AND BIOSYNTHESIS OF ALBU$M I N$

1-3a. Structure and function of albumin

1-3b. Albumin biosynthesis 26

1. Albumin gene and albumin gene transcription 26

2. Translation and post-translational modifications 27

3. Factors influencing albumin synthesis 28

1-4. ALBUMIN ELIMINATION 29

1-5. THE AIM OF THE STUDY 29

II AGE-RELATED CHANGES IN ALBUMIN ELIMINATION IN FEMALE WAG/Rij RATS

11-1. INTRODUCTION 31

II-2. MATERIALS AND METHODS 32

11-2a. Animals and materials 32

$11-2 b$. Assays 32 
1. Albumin isolation, purification and labeling with 125,

2. Plasma radioactivity curves

3. Plasma albumin concentration, the whole-body albumin pool and the absolute and fractional rate of albumin elimination

11-3. RESULTS 36

11-3a. Plasma radioactivity curves

$11-3 b$. Albumin concentration in the plasma, the whole-body albumin pool and the absolute and fractional rate of albumin elimination

11-4. DISCUSSION

III CHANGES IN URINARY ALBUMIN EXCRETION, GASTROINTESTINAL PROTEIN LOSS AND FLUID-PHASE ENDOCYTOSIS WITH AGE AND THEIR RELATION TO TOTAL ALBUMIN ELIMINATION

III-1. INTRODUCTION

111-2. MATERIALS AND METHODS

III-2a. Animals and materials

1il-2b. Assays

1. Urinary albumin excretion

2. Gastrointestinal protein loss

3. Fluid-phase endocytosis 46

- Plasma radioactivity curves

- Measurement of total radioactivity in organs and tissues

- Calculations

- Urinary excretion of ${ }^{125}$ 1-PVP

III-3. RESULTS

111-3a. Urinary excretion of albumin

$111-3 b$. Gastrointestinal protein loss 
1II-3c. Fluid-phase endocytosis

- Plasma radioactivity curves

- Urinary excretion of 1251-PVP

- 125 1-PVP clearance by organs and tissues

111-4. DISCUSSION

IV CHANGES IN THE SEQUENCE CONTENT OF ALBUMIN MRNA AND IN ITS TRANSLATIONAL ACTIVITY IN THE RAT LIVER WITH AGE

IV-1. INTRODUCTION

IV-2. MATERIALS AND METHODS 60

IV-2a. Animals and materials 60

IV-2b. Assays 61

1. Isolation of total post-nuclear RNA 61

2. Preparation of poly $(A)$-containing RNA 62

3. Isolation of free and membrane-bound polyribosomes $\quad 62$

4. Preparation of cell sap 63

5. Polyribosome profile analysis 63

6. Quantitative determination of the RNA content 63

7. Cell-free protein synthesis 64

8. In vitro translation in a reticulocyte lysate 64

9. Immunological analysis of albumin synthesis in cell-free reactions 65

10. Preparation of $\left({ }^{14} \mathrm{C}\right)$-albumin 66

11. Analytical RNA-CDNA hybridization 66

IV-3. RESULTS $\quad 66$

IV-3a. Yield and size of isolated polyribosomes 66

IV-3b. Cell-free incorporation of labeled amino acid into total protein and albumin 69

IV-3c. RNA content in various subcellular fractions 69

IV-3d. Albumin mRNA sequence content 71 
IV-3e. In vitro translation of rat liver poly $(A)^{+}-$RNA

IV-4. DISCUSSION

V. THE MOLECULAR BASIS OF THE AGE-RELATED INCREASE IN ALBUMIN MRNA LEVELS IN RAT LIVER

V-1. INTRODUCTION

$V-2$. MATERIALS AND METHODS

$\mathrm{V}-2 \mathrm{a}$. Animals and materials

$\mathrm{V}-2 \mathrm{~b}$. Assays

1. Determination of the transcriptional activity of the rat albumin gene in isolated nuclei

- Isolation of rat liver nuclei

- Transcription by isolated nuclei

2. Determination of the relative abundance of albumin-specific RNA sequences in rat liver nuclei

- Isolation of nuclear and cytoplasmic RNA

- Dot-blot hybridization

3. Size determination of poly $(A)$-tails of rat liver cytoplasmic RNA

$V-3$. RESULTS

$V-3 a$. The transcriptional activity of the rat albumin gene with age

$\checkmark-3 b$. The relative abundance of albumin-specific RNA sequences in rat liver nuclei

$V-3 c$. The size of poly $(A)-t a i l s$ in total cytoplasmic RNA isolated from rat liver

V-4. DISCUSSION 
VI-1. INTRODUCTION

VI-2. MATERIALS AND METHODS 100

VII-2a. Animals and materials

VI-2b. Assays

1. Albumin isolation, purification and labeling with 125 ,

2. Plasma radioactivity curves

3. Plasma albumin concentration, plasma protein concentration, the whole-body albumin pool and the absolute rate of albumin elimination

4. Urinary albumin and total protein excretion

5. Quantitative determination of the total liver RNA content and the albumin mRNA content

6. Histology

7. Statistical correlation

V1-3. RESULTS

VI-3a. . Survival characteristics of the rats used in thils study

VI-3b. The influence of age on the measured characteristics

- Body weight

- Plasma volume

- Elimination half-life of albumin

- Albumin clearance

- Apparent volume of distribution of albumin

- Plasma albumin and protein concentrations

- Absolute albumin elimination rate and wholebody albumin pool

- Albumin and protein excretion via the urine

VI-3c. Total liver RNA content and albumin mRNA content 
VII-1. ALBUMIN ELIMINATION AND AGING

VII-2. ALBUMIN SYNTHESIS AND AGINIC

VII-3. CORRELATION BETWEEN ALBUMIN ELIMINATION AND SYNTHESIS WITH AGE

VII-4. THE MOLECULAR BASIS OF THE INCREASED ALBUMIN MRNA CONTENT WITH AGE

VIII-1. ALBUMINEELIMINATIE EN VEROUDERING

VIII-3. DE CORRELATIE TUSSEN ALBUMINEELIMINATIE EN SYNTHESE MET VEROUDERING

VIII-4. DE MOLECULAIRE BASIS VAN DE TOENAME IN DE HOEVEELHEID ALBUMINE-mRNA MET VEROUDERING 



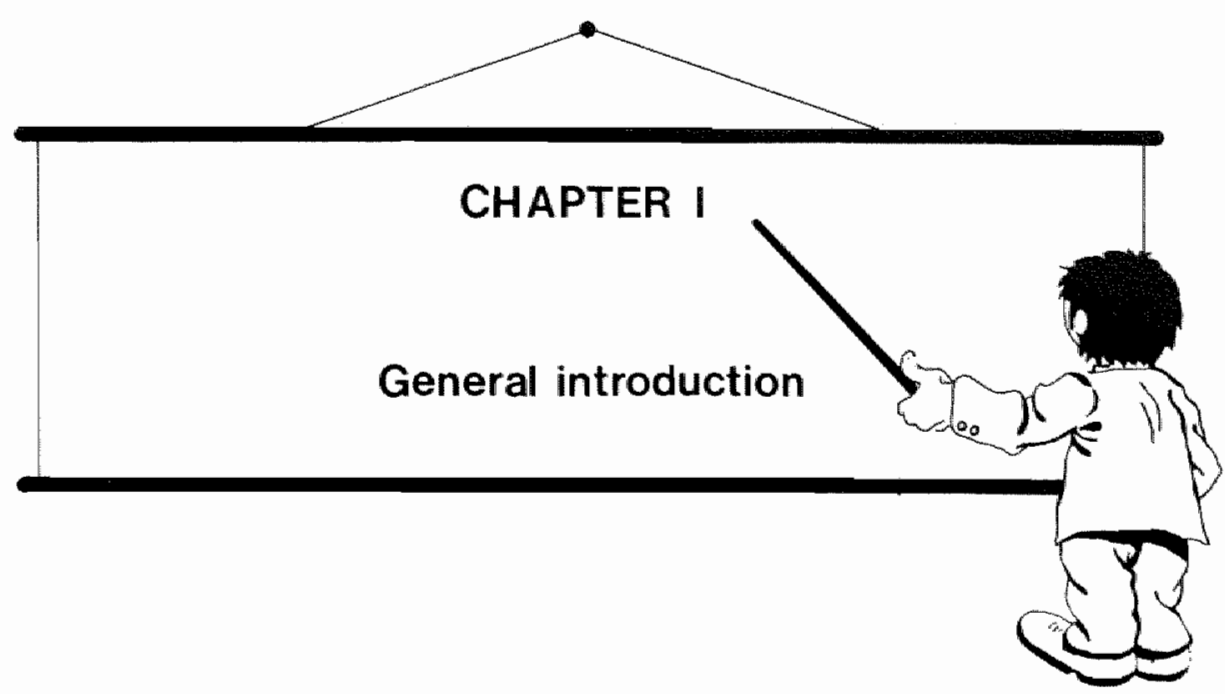

Aging of an organism is a complex process comprising numerous changes which arise in a time-dependent manner. An adequate definition has proven illusive. The more precise the definition, the easier to criticise it and the most innocuous definitions are too vague to be helpful. Notwithstanding, investigators into aging and age-related phenomena require some sort of framework in which to operate and to evaluate the findings of others. Strehler (1959) attempted to circumvent the difficulties by proposing four criteria which should be satisfied before ascribing any property or process to aging. In effect, these are general definitions of biological aging. Firstly, a change with age should be universal, so that it should occur in all older members of the species. Secondly, the change should be intrinsic, which means that aging is a property of the organism and not of the environment. Thirdly, it should be progressive. Aging is a process rather than a sudden event and therefore it should be gradual and cumulative. Fourthly, the change should be deleterious and therefore contribute to 
the increased probabillity of death.

When these criteria are examined, it seems highly likely that the basic process of aging has a strong genetic component and there are several lines of evidence which support this assertion. As far as longevity is concerned, several studies (reviewed by Murphy, 1977) indicate that genetic factors are involved. It has been shown that identical twins are more alike than are non-identical twins with respect to longevity. Furthermore, there appears to be a correlation between the life expectancy of the children and the survival of the parents. The question arises, whether there is also evidence for genetic influences in more specific aspects of aging. Martin (1977) estimated that several thousand genetic loci are capable of influencing the aging phenotype, but fewer than 100 seem to exert major effects. Less than 10 genetic loci have profound effects on aging and are seen in a relatively pure form in the rare premature aging syndromes.

The consideration that the lifespan of organisms is partially under genetic control has led several investigators to propose that changes occurring in gene structure and expression could be one of the mechanisms involved in the aging process. Among these theories several relate to the role of protein synthesis and protein function. The nowadlays discredited "error catastrophe theory" of Orgel $(1963 ; 1973)$ suggests that errors in the transmission of information from DNA to RNA to protein result in the production of altered proteins. These altered proteins might influence the transcriptional and translational processes, which might result in an escalation of errors. Changes in protein populations with age are also involved in the deamidation theory (Robinson et al. 1970), which predicts charge changes in proteins; in the cross-linkage theory (Björksten, 1974), which suggests an age-related increase in covalently bound aggregates of proteins; as well as in the somatic mutation theory (Failla, 1958; Szilard, 1959: Curtis, 1966), the codon restriction hypothesis (Strehler et al., 1971) and the autoimmune theory (Walford, 1969), which all predict age-related changes in protein types.

It is generally considered to be improbable that a single theory 
will explain all aspects of aging. Aging should be wiewed as a complex phenomenon which may require different explamatory mechanisms for different aspects of the aging process, which will therefore bie the result of interdependent and multiple mechanisms. Although the notion of a genetic component in the process of aging might well be valid. one must not lose sight of the fact that in an integrated system $11 . e$. an organism), the aging process could be more complex than can be explained by isolated phenomena at a particular level of organisation (e.g. DNA). Knook (1982) stated that changes at the cellular level milght have an impact on the physiological functions of an organ. which in turn might influence life expectancy. Therefore, it is often wery difficult to distinguish between cellular and extracellular causes of physiological changes with age. In the study presented in this monograph the rat has been selected as a suitable subject for investigation into age-related changes in albumin metabolism. Albumin is of particullar relevance since its metabolism might conceivably be influenced by changes at any one of the number of levels of organisation, none of which are mutually exclusive.

Although changes in protein metabolism with age have been studied extensively (for a review see Richardson, 1981; Richardson \& Birchenall-Sparks, 1983; Makrides, 1983), it is still not completely clear what influence these changes in protein synthesis and/or ellimination might have on the aging process. Nevertheless, several indications of correlations between changes in protein metabolism and in protein levels with an age-related functional decline exist. For instance, changes in protein synthesis have been implicated in the pathogenesis of semile dementia (McMartin \& Schedlbauer, 1975; Mann et al., 1981). A dew crease in total brain protein and tubulin synthesis might be related to the pathogenesis of the senile plaques found in old humans and animals (Wisniewski \& Terry, 1973). In addition, changes in protein synthesis might play a rolle in the reduction in enzyme activity in the cholinergic system, which is a dominant feature of Alzheimer's disease (Corkin, 1981). Age-related changes in protein catabolic rates might contribute to the altered levels of some enzymes (Florini, 1975; Wilson, 1981) and 
to the increased protein content in senescent cells (Wilson, 1972).

The remaining part of this chapter will give an overview of age-related changes in protein synthesis and elimination in rodents with special reference to the synthesis and elimination of serum albumin.

1-1. AGE-RELATED CHANGES IN PROTEIN SYNTHESIS IN RODENT LIVER

1-1a. General aspects of protein synthesis with age

Most of the investigators who have studied protein synthesis with age have used rodents as an animal model. Such an animal model is used to establish facts which might lead to better understanding of what happens in man. To extrapolate data obtained in the animal model to the human situation, the model has to fullfill at least two requirements. The animals should sustain pathological changes that resemble the pathological changes ocurring in man, and furthermore, should have similar survival characteristics (Zurcher et al., 1982), i.e, a survival curve with a more or less rectangular shape. With the aid of this survival curve one can standardize what an "aged" animal is, i.e. an animal that is older than the $50 \%$ survival age. Long-lived inbred strains of rats and mice are currently being employed in the majority of aging research programmes, partly because they fullfil the requirements mentioned above. Most of the studies on protein synthesis utilised in cell-free systems from liver tissue. Beauchene et al. (1967) and Chen et al. (1973) reported no change with age in cell-free protein synthesis using microsomes from rat liver. while Bolla $\&$ Greenblatt (1982) observed an initial decline early in adult life in protein synthetic activity followed by an increase late in old age. Studies using mouse liver ribosomes (Shmookler Reis, 1981) revealed no change in cell-free protein synthesis when using endogenous messenger RNA's, but poly(U)directed synthesis was increased with age. All other studies showed a generalised decrease in cell-free protein synthesis using microsomes from rat (Hrachovec, 1971; Buetow \& Ghandi, 1973; Comolli, 1973; Hallthaler et al., 1976) or from mouse liver (Main- 
waring, 1969; Kurtz, 1975; Kurtz, 1978), postmitochondrial supernatant from rat (Layman et al., 1976) or from mouse liver (Blazejowski \& Webster, 1983) and ribosomes from rat liver (Hrachovec, 1971).

The influence of aging on liver protein synthesis has also been studied using isolated hepatocytes. Viskup et al. (1979) reported an age-related decrease in the capacity of isolated hepatocytes to synthesise proteins. Van Bezooijen et al. [1977) measured the incorporation of ${ }^{14} \mathrm{C}$-leucine by hepatocytes isolated from female WAG/Rij rats of different ages. They observed that protein synthesis decreased between 3 and 12 months, remained constant between 12 and 24 months and increased between 24 and 36 months of age. Furthermore, the initial decline depended on the sex and strain of the rats used. However, the increase in advanced age was independent of sex and strain (Van Bezooijen et al. 1981). The same biphasic response with age was observed by Coniglio et al. (1979), who measured the rate of valine incorporation by hepatocytes isolated from male Fischer 334 rats.

The in vivo incorporation of radioactively labeled amino acids into proteins in the liver has also been studied. Beauchene et al. (1970) and Ove et al. (1972) reported no age-related changes. Comolli et al. (1972) observed a slight decrease with age, while Kanungo et al. (1970) found an increase with age.

Most of the studies on the synthesis of specific proteins in the liver with age have focussed on albumin (reviewed in Chapter IV), though some other proteins have also been studied. Ove et al. [1972) reported that the in vivo synthesis of ferritin in rats increased with age. Bolla $\&$ Greenblatt (1982) studied transferrin synthesis in rat liver microsomes and observed an age-related decrease. The synthesis of P20,000, a protein of the rat liver endoplasmic reticulum, decreases with age in isolated hepatocytes (Viskup et al. "1981; Penniall et al., $1981)$.

In order to gain insight into the molecular mechanisms which underly the age-related changes in the protein synthetic activity of rodent liver, various aspects of the synthetic process have been studied. These aspects can be divided into two groups: 1) RNA synthe- 
sis and mRNA levels and 2) the components of the translational apparatus.

1-1b. Age-related changes in RNA synthesis and mRNA levels

Total RNA synthesis has as a function of age been studied in vivo in mice (Fog \& Pakkenberg, 1981) and in rats (Samis et al., 1964; Kanungo et al, 1970; Martin E Martin, 1977), in isolated liver nuclei of mice (Davi et al, 1966; Mainwaring, 1968; Britton et al., 1972) and of rats lGibas \& Harman, 1970; Denckla, 1977; Castle et al., 1978; Bolla \& Denckla, 1979; Lindell et al. "1982; Richardson et al., 1985). in liver slices of mice and rats (Beauchene et al., 1967) and in isolated hepatocytes of rats (Kreamer et al., 1979; Richardson et al., 1982). Apart from the studies of Samis et al. (1964) and Martin $\varepsilon$ Martin $[1977)$, who found an age-related increase in in vivo RNA synthesis by rats, and the study of Gibas $\&$ Harman (1970), who observed no change with age in RNA synthesis by isolated rat liver nuclei, all other reports indicated an age-related decline in this process.

By determining the effect of age on the synthesis of total RNA, changes in specific RNA-types go undetected. Although the expression of the different classes of RNA (e.g. tRNA, rRNA and mRNA) has been reported to be under a separate control, this overview will focus only on mRNA, since it plays a critical role in the transfer of genetic information. Since most mRNA molecules in eukaryotes contain a poIy (A)-segment on the 3'- end of the molecule (Lim et al. 1970; Minty \& Gross, 1980), investigators are equipped with a tool to isolate this mRNA (poly (A) ${ }^{+}$-RNA) by means of affinity-column chromatography. No change with age was found in the poly $(A)^{+}$-RNA content expressed per total amount of polyribosomal RNA in the rat liver (Moudgil et al. 1979) nor in the translatibillity of this RNA (Birchenall-Sparks et al. 1985). The turnover of this RNA was decreased with age (Moore et al. 1980 ) as was the synthesis rate of poly $(A)^{+}-R N A$ in isolated hepatocytes (Richardson et al. 1982).

As far as the content of specific mRNA"s is concerned, few data are 
available. Investigations in this area are often indirect. Chatterjee et al. (1981) studied classes of mRNA from rat liver by translating poIy $(A)^{+}$-RNA from young and old animals in a reticulocyte lysate and comparing the translation products. In this in vitro translation system the amount of specific protein formed is used as a measure for the amount of specific mRNA present in the poly(A) ${ }^{+}$-RNA population. They observed age-related changes in these translation products, and thus presumably in the mRNA's. Some mRNA's appeared late in age and some disappeared. Anzai et al. (1983) performed similar studies in mice. They observed in senescent mice the occurrence of a protein product with a molecular weight of 30,000 and an isoelectric point of 6.5, which was absent in young mice. Dilella et al. (1982), also using an in vitro translation assay. showed that the amount of cytochrome $P-450$ mRNA in rabbits is decreased with age.

A more direct approach to the study of age-related changes in mRNA levels is by molecular hybridization techniques. Guigoz \& Wellinger (1984) performed such studies in rats for tyrosine aminotransferase mRNA and tryptophan oxygenase mRNA. For both mRNA's, expressed relative to the amount of albumin mRNA's, they observed lower levels in old rats when compared to young ones. In a study by Richardson et al. (1985) some other mRNA's were studied. They showed an age-related decrease in the levels of cytochrome P-450 mRNA and $a_{2 u}$-globulin mRNA, expressed relative to the amount of total RNA, in Fischer 344 rats. Aldolase mRNA levels remained unchanged with age, while albumin mRNA levels increased after 24 months of age. The influence of age on albumin mRNA levels will be discussed in detail in Chapter IV.

1-1c. The influence of the components of the translational apparatus on the changes in protein synthesis with age

In the study of the roles of the various components of the protein synthetic apparatus in the age-related changes in protein synthesis in rodent liver, much attention has been given to the activity of ribo- 
somes and to ribosome aggregation to mRNA. The activity of ribosomes has been studied by their translational capacity for polyuridylic acid (poly (U)). Some of these studies report an age-related decrease in poly(U)-directed polyphenylalanine synthesis by rat liver ribosomes (Kurtz, 1975; Kurtz, 1978) and by mouse liver ribosomes (Mori et al.. 1979). Bielka et al. (1976) found no change with age in the poly(U)translating activity of rat liver ribosomes, while Shmookler Reis (1981) showed an age-related increase in this activity of mouse liver ribosomes. Poly[U] is an artificial template that precludes any assessment of normal initiation and termination. Furthermore, it has been shown that the fidelity of translation is 100 -fold less in this system than it is in vivo due to artefactual stabilization of "nonspecific" interactions (Topal \& Fresco, 1976). More meaningful results could be obtained with endogenous mRNA's.

Layman et al. (1976) suggested that the age-related decrease in liver cell-free protein synthesis was due to a decrease in ribosome aggregation to mRNA. This is consistent with the findings of Mainwaring (1968) and Vandenhaute et al. (1983). However. Moudgil et al. (1979) did not observe any such decline. It has been suggested that the basis for this decrease in ribosome aggregation was an age-related decrease in the initiation of protein synthesis (Comolli, 1975; Comolli et al., 1977; Vandenhaute et all., 1983). Claes-Reckinger et al. (1982), using rat liver polyribosomes, observed a progressive decrease in ribosome aggregation until 24 months of age followed by a marked increase. Initiation processes were reported not to change with age in mouse (Blazejowski $\varepsilon$ Webster, 1984) or in rat liver (Gabius et all., 1983), but the decrease in protein synthesis was suggested to be due to a decrease in peptide chain elongation (Blazejowski $\&$ Webster, 1984) and/ar to a decrease in the binding of aminoacyl-tRNA to the ribosome and a lower rate of peptidyltransfer (Gabius et al., 1983). Studies on the elongation factors EF-1 and EF-2 showed that the activity of EF-1, which catalyzes the binding of aminoacyl-tRNA to ribosomes, decreased with age (Moldave et al., 1979; Webster $\varepsilon$ Webster, 1982), while no age-related change was observed in the activity of EF-2 which is in- 
volved in the translocation step (Moldave et al., 1979).

$1-1 d$. Possible sources of differences in experimental results

It is clear that the published data on protein synthesis and aging are often variable and contradictory. A few very important reasons that might explain this variability will now be briefly considered.

One important variable which might influence the outcome of experimental results is the use of animals of differing species, strain and sex (Wilson \& Franks, 1971; Eurich et al., 1980; Van Bezooijen et al., 1981). Furthermore, diet and environmental conditions could also influence the outcome of the various studies.

Perhaps the most important source of variability in the results is that animals of a given age may not be directly comparable (Florini, 1975). Often no reference is made to the survival characteristics of the strain used in the study. Without such information it is impossible to compare the different studies and to correlate the results with the developmental status of the animal. Furthermore, most investigators used only two age groups (often called "young" and "old"), and no information was given about the interim course of the process measured. Several studies have reported a biphasic response in protein synthesis with age (Van Bezooijen et al., 1977; Coniglio et al., 1977; Van Bezooijen et al., 1981; Bolla \& Greenblatt, 1982). It is therefore possible that some of the differences in results concerning age-related changes in protein synthesis are due to the choice of age-groups.

In order to study age-related changes, one has to keep in mind that the young animals should be sexually mature so that developmental changes are not misinterpreted. The old group should consist of animals that are older than the 508-survival age and interim age-groups should be used to detect possible biphasic changes with age. 
Table 1-1 AGE-RELATED CHANGES IN LIVER ENZYME DEGRADATION HALF-LIVES IN RODENTS

Enzyme

Glucose-6-phosphate

dehydrogenase (rat)

a-glycerophosphate

dehydrogenase (rat)

Citrate cleavage enzyme (rat)

Malic enzyme (rat)

Ornithine decarboxylase (mouse)

Aldolase (mouse)

$\leftarrow \rightarrow$ : no change

+ : decrease

$\uparrow$ : increase
Change Literature reference

$+\quad$ Richter, 1977

$+\quad$ Richter, 1977

$+\quad$ Richter, 1977

$+\quad$ Richter, 1977

$\uparrow \quad$ Jacobus \& Gershon, 1980

$\uparrow \quad$ Reznick et al., 1981

1-2. THE INFLUENCE OF AGE ON PROTEIN ELIMINATION PROCESSES

As far as protein elimination processes with age are concerned only a limited amount of information is available. The studies have focused on protein degradation in tissues and organs, enzyme degradation, and whole body protein turnover. Whole-body protein turnover with age was determined in rats (Yousef $\varepsilon$ Johnson, 1970) and in mice (Sobel $\varepsilon$ Bowman, 1971). Both groups observed a slower turnover in old animals as compared to young ones. 
Lavie et al. (1982) determined protein degradation rates in liwers of mice of different ages. They abserved an age-related increase in the half-lives of short-lived proteins in the nuclear. mitochondrial and lysosomal fractions and in the total acid-precipitated proteins. Wiederanders (1981) found an increased half-life of liver cytosol proteins in rats with age. Protein degradation in cultured mouse hepatocytes did not change with age (Burrows $\&$ Davidson, 1983). With regard to specific proteins, studies have been performed on ferritin and albumin elimination with age. Ferritin had half-lives of 1.9 days and 4.0 days in young and old rats, respectively (Ove et al., 1972). These results were confirmed by Obenrader et al. [1974]. Albumin elimination with age will be discussed in Chapter 11 .

Enzyme degradation rates in rodent liver has been studied by several groups. The data are presented in Table 1 . It can be seen that there is no consistency with regard to the influence of age on the degradation of liver specific enzymes.

\section{1-3. BIOCHEMISTRY AND BIOSYNTHESIS OF ALBUMIN}

$1-3 a$. Structure and function of albumin

Albumin is a protein synthesised in the liver and readily secreted into the circulation. It is an abundant plasma protein, comprising about one half of the total plasma protein pool and has a molecular weight of about 65,000 (Peters, 1962). The primary structure is that of a single polypeptide chain of approximately 570-580 amino acids and has no prosthetic group (Peters, 1962; Urban et al., 1974). Serum albumin consists of three weakly homologous structural domains (Brown, 1976). This internal homology of the protein is also evident in the nucleotide sequence of rat serum albumin mRNA (Sargent et al., $1981 \mathrm{~b})$ and is clearly present in the structure of the serum albumin gene (Jagodzinski et al., 1981).

Albumin has a major role in the maintenance of the colloid osmotic pressure of the plasma as well as serving as a carrier pratein for metals, anions, fatty acids, bilirubin, hormones and drugs (Rothschild 
et al. 1972). Several reports indicate that albumin-binding might facilitate hepatic uptake of fatty acids and arganic anions via an albumin receptor on the liver parenchymal cells (Weisinger et all., 1981; Hütter et al., 1984; Fleischer et al. "1985).

Recentlly an enzymatic function of serum albumin has been described. Fitzpatrick \& Wynalda (1981) reported that serum albumin catalyzes the dehydration of prostaglandin $E_{1}$ to prostaglandin $A$. A similar dehydration of prostaglandin $D_{2}$ was also shown to be catalyzed by serum albumin (Fitzpatrick \& Wynalda, 1983; Kikawa et al. . 1984).

1-3b. Albumin biosynthesis

1. Albumin gene and albumin gene transcription

The albumin gene is a single copy gene: i.e., it occurs only once per haploid genome. The exact size and location of the exons have been obtained by sequence determination, restriction mapping and $\mathrm{R}$-loop analysis (Sargent et al., 1979; Sargent et al., 1981a). The gene contains 15 exons and 14 introns and spans 14,900 nucleotides of which 12,900 are intronic. The internal periodicity of the albumin gene has been demonstrated by statistical analysis of its $M R N A$ sequence (Sargent et $\mathrm{al}, 1981 \mathrm{~b}$ ). The albumin gene could be divided into three weakly homologous subgenes, each comprising four exons and corresponding to a structural domain of the albumin polypeptide (Brown, 1976).

The transcription of the albumin gene is under developmental control (Liao et al. "1980). The amount of albumin mRNA expressed relative to the amount of total RNA is 10-fold higher in the liver of an adult rat than in 15 -day-old fetuses. This regulation is believed to occur at the level of methylation of the gene (Kunnath E Locker, 1983; Muglia \& Locker, 1984), at the level of transcription (Tilghman $\&$ Belayew, 1982) but not by post-transcriptional control (Nahon et al. $1982)$.

Rat albumin mRNA has been isolated by several groups (Taylor $\varepsilon$ Tse, 1976; Strair et al., 1977; Hofer et al., 1979; Sala-Trepat et al., 
1979) and its nucleotide sequence has been established (Sargent et al., 1981b). Albumin mRNA has a sedimentation coefficient of about 17S. It possesses a chain length of 2265 nucleotides, of which 330 are untranslated nucleotides and about 100 more are accounted for by the poly (A)-region (Sala-Trepat et al., 1979).

2. Translation and post-translational modifications

Albumin is synthesised by membrane-bound polyribosomes, as is the case for other proteins which are secreted (Hicks et al., 1969; Yap et al., 1977), although free polyribosomes do contain a low level of albumin mRNA sequences (Princen et al., 1982; Horbach et al., 1984a). Initially, the albumin mRNA is translated into a larger molecule (preproalbumin) with a octadecapeptide extension to the amino-terminal end of proalbumin (Strauss et al., 1977; Yu\& Redman, 1977). The role of this extension is thought to be a signal that aids in the attachment of the allbumin-synthesising polyribosomes to the endoplasmic reticulum membrane (Blobel \& Dabberstein, 1975). This signal portion of nascent albumin is cleaved during the vectorial transport of pre-proalbumin into the lumen of the endoplasmic reticulum. The major intracellular nascent form of albumin is proalbumin, which contains a hexapeptide extension. This additional aminoterminal sequence has been described as Arg-Gly-Val-Phe-Arg-Arg (Urban et al., 1974; Russel \& Geller, 1975; Quinn et al., 1975). The function of the propeptide might be to aid the channeling of proalbumin along the cytoplasmic membranes in lieu of the glycosyl groups which become attached to most secreted proteins (Judah \& Quinn, 1976; Peters \& Reed, 1980). This basic hexapeptide is removed from proalbumin late in the secretory process. producing albumin with an aminoterminal glutamic acid. The exact intracellular sites of conversion of proalbumin to serum albumin are not clear since in isolated hepatocytes conversion may occur in both the smooth endoplasmic reticulum and the Golgi complex (Edwards et al., $1976)$ but in vivo it appears to occur mostly in the Golgi complex, 
predominantly in the secretion vesicles (Ikehara et al. "1976; Redman et al., 1978; Franz et al., 1981).

\section{Factors influencing albumin synthesis}

Nutrition is one of the most important factors influencing the rate of protein synthesis (Munro et al., 1965; McNurlan et al., 1979; Princen et al., 1983) and albumin synthesis (Rathschild et al., 1974; Pain et al., 1978; MCNurlan et al., 1979; Princen et al., 1983). Fasting has been shown to reduce total hepatic cellular RNA by increasing the rate of degradation of RNA and decreasing its synthesis (Enwonwu $\varepsilon$ Munro, 1970; Ramsey \& Steele, 1976). A disaggregation of liver polyribosomes has been observed in association with fasting (Rothschild et al., 1974; Yap et al., 1978). Restoration of protein synthesis could be accomplished by the re-feeding of amino acid mixtures (Baliga et al., 1968; Rothschild et al., 1974; Sato et al., 1974) or glucose (Princen et al. 1983). It was shown that the stimulation of the albumin synthesis

by arginine and ormithine was caused by an increased synthesis of polyamines (Orate'et al., 1983). The hydrolysis of arginine in the krebs cycle produces ornitline, which is a precursor of polyamines (Maudsley, 1979). Polyamines play an important role in maintaining polyribosomal integrity (Khawaja, 1972; Oratz et al., 1980; Sidransky et al., 1982; Oratz et al., 1983).

Thyroid hormone and cortisone have been shown to increase both albumin synthesis and elimination (Rothschild et al., 1957). Roy $E$ Dowbenko (1977) demonstrated an effect of growth hormone on albumin synthesis. Hypophysectomy, resulting in an absence of growth hormone, decreased albumin mRNA levels, which could be restored by growth hormone replacement alone (Kernhoff et al., 1971; Keller \& Taylor, 1976).

Acute exposure to ethanol is associated with disruption of the endoplasmic reticulum membrane (Rubin \& Lieber, 1968) and a disaggregation of membrane-bound polyribosomes and a rapid decrease in albumin 
synthesis is obserwed when adding ethanol in liver perfusate directly (Rothschild et al., 1974; Oratz et al., 1976). Princen et al. (1981), however. showed that oral intake of ethanol 3 hours before killing did not influence the yield or size of either free or membrane-bound polyribosomes and had no effect on albumin and total protein synthesis. In addition, the albumin mRNA sequence content did not change. The discrepancy between these studies can be explained by the experimentall differences. By the addition of ethanol in liver perfusate or suspension medium directly, the influences of ethanol on the extrahepatic regulatory mechanism of protein synthesis in the liver is excluded.

Albumin synthesis is also under an age-related control. This aspect of albumin synthesis will be dealt with in Chapter IV.

\section{1-4. ALBUMIN ELIMINATION}

The introduction of radioiodine-labeled albumin (Sterling, 1951) made it possible to study the degradation of albumin in animals and man. Intravenous injection of iodinated albumin in rats revealed a plasma disappearance curve consisting of two phases, with an elimination half-life of 46 hours (Hawkins, 1961) or 46-65 hours (Katz et al., 1963). Albumin has both a plasma and an extravascular pool. These two compartments are readily equilibrated. McFarlane and Koj (1970) suggested that the compartment in which albumin is degraded is in rapid equilibrium with the plasma, but is not the plasma nor the extracellular pool itself. An overview on the tissue sites of albumin degradation will be given in Chapter $\| 11$.

Apart from tissuelorgan degradation, albumin elimination also occurs by urinary excretion and by gastrointestinal protein loss. These two aspects will also be dealt with in Chapter III.

1-5. THE AIM OF THE STUDY

Protein metabolism can be divided into two components: synthes is and elimination. The equilibrium between these two processes will yield 
steady-state protein levels which is very important for maintenance of homeostasis.

Many studies have been performed on the influence of age on protein metabolism. However, the results are quite often contradictory. Apart from experimental differences between the various studies, another reason for the variability in the results is that there seems to be no uniform control mechanism for the metabolism of individual proteins with age. It would therefore be useful to study the synthesis of a specific protein together with its elimination in the same animal species and strain in order to gain a better understanding of the involvement of aging in protein metabolism. Rat serum albumin was chosen for this study, since previous studies had shown that the synthesis of this protein was under an age-related control. A summary of these studies will be given in Chapter IV.

The aim of the study presented here is to determine age-related changes in albumin metabolism in female WAG/Rij rats. These rats were chosen because they meet the requirements for an animal model in aging research as described previously. The 90,50 and 108 survival age of this rat strain was 26, 32 and 38 months, respectively. The rats were kept under "clean conventional" conditions as described by Hollander (1976).

Chapter II will deal with the influence of age on albumin elimination in vivo. The contribution of several albumin elimination processes isuch as urinary excretion, gastruintestinal protein loss and fluidphase endocytosis l to these changes will be dealt with in Chapter III. Chapters IV \& $V$ will deal with the molecular basis of age-related changes in albumin synthesis in rat liver. In Chapter VI a longitudinal study will be described on the albumin elimination rate. 


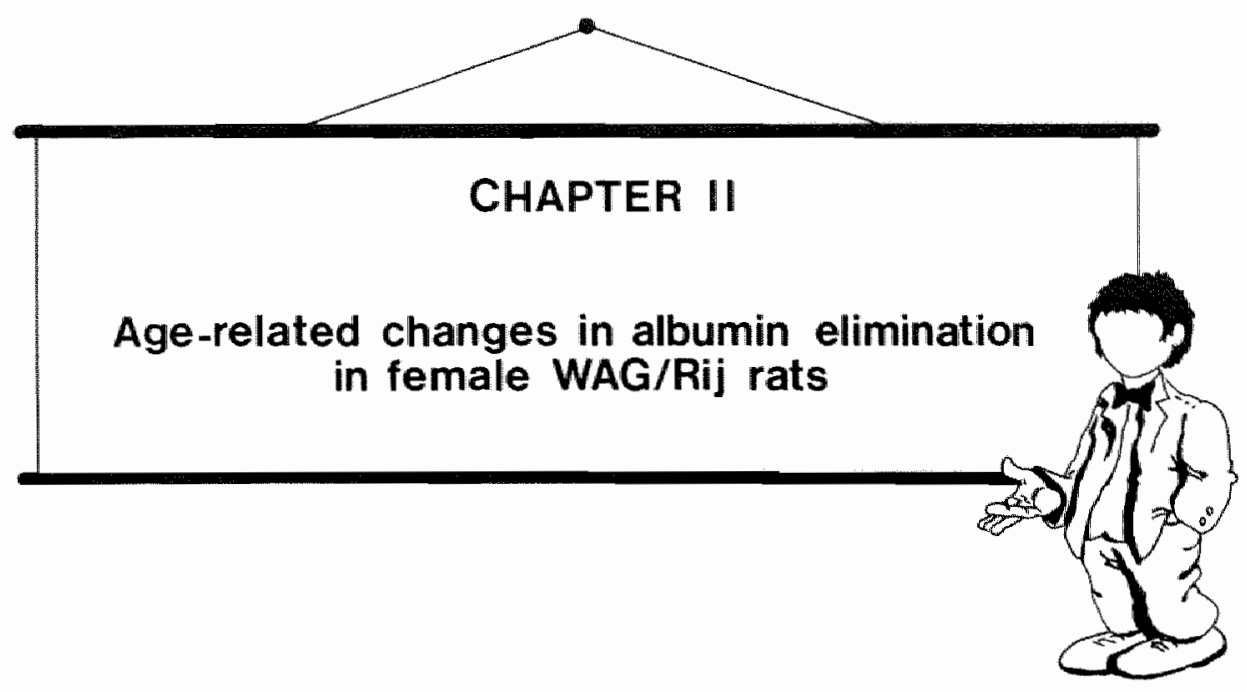

1I-1. INTRODUCTION

In studying age-related changes in albumin metabolism, very little attention has been paid to age-related changes in total albumin elimination and very few reports on this topic have been published (Salatka et al., 1971; Ove et al., 1972; Quinn et al., 1973). Moreover, these investigators expressed the elimination rate of albumin as a relative index, the elimination half-life. Only Quinn et al. (1973) found an agerellated change in this index in mice with a sharp increase in the elimination half-life very late in life. Unfortumately these investigators did not measure the whole-body albumin pool and were therefore unable to determine the absolute albumin elimination rate.

This chapter will focus on the age-related changes in the absolute albumin elimination rate in rats. 


\section{1-2a. Animals and materials}

The mean weights $( \pm$ S.D.) of the $3-, 12-, 24-$ and 36 -month-old female WAG/Rij rats were $151 \pm 13,182 \pm 16,208 \pm 16$ and $186 \pm 20 \mathrm{~g}$, respectively.

DEAE Affi-Gel Blue was obtained from Bio-Rad Laboratories (Richmond, $C A, U S A)$. The goat anti-(rat total serum proteins) antiserum used for immunoelectrophoresis (GARa/ielfo) and rabbit anti-(rat serum albumin) antiserum (RARa/Alb) were abtained from Nordic Immunological Laboratories (Tilburg. The Netherlands). ${ }^{125}$, was obtained from the Radiochemical Centre (Amersham. Bucks, UK). Minicon B-15 macrosolute concentrators were obtained from Amicon, Ltd. [Woking, Surrey, UK).

\section{$11-2 b$. Assays}

1. Albumin isolation, purification and labeling with 125 ,

The isolation and purification of albumin was achieved by chromatography of fresh rat serum on DEAE Affi-Gel Blue. DEAE Affi-Gel Blue is an affinity matrix made by coupling Cibracon Blue F3GA to specially prepared DEAE-BIO-GEL A. A column with a total bed volume of 7 $\mathrm{ml} / \mathrm{ml}$ of serum was prepared. The column was pre-washed with two bed volumes of $0.02 \mathrm{M} \mathrm{K}_{2} \mathrm{HPO}_{4}, \mathrm{pH} 8.0$ (Buffer 1). The serum sample was dialysed for 24 hours against Buffer 1 . The serum sample was applied to the column and the column washed (in sequence) with 3-4 bed volumes of Buffer $1 ; 2$ bed volumes $0.1 \mathrm{M} \mathrm{K}_{2} \mathrm{HPO}_{4}, \mathrm{pH} 8.0 ; 2$ bed volumes of $0.2 \mathrm{M} \mathrm{K}_{2} \mathrm{HPO}_{4}, \mathrm{pH} 8.0 ; 1$ bed volume of $0.4 \mathrm{M} \mathrm{K}_{2} \mathrm{HPO}_{4}, \mathrm{pH} 8.0$ and 2 bed volumes of Buffer 1 . The column was eluted with 2 bed volumes of $1 \mathrm{MKSCN}$. The albumin and the $K S C N$ were separated by chromatography on a Sephadex G-50(medium grade) column equilibrated with phosphate buffered saline $\left(24 \mathrm{mM} \mathrm{KH_{2 }} \mathrm{PO}_{4} / 63 \mathrm{mM} \mathrm{K}{ }_{2} \mathrm{HPO}_{4} / 154 \mathrm{mM}\right.$ 
$\mathrm{NaCl}, \mathrm{pH} 7.4)$. The albumin-containing fractions were pooled and concentrated on Minicon B-15 concentrators to a final concentration of approximately $10 \mathrm{mg} / \mathrm{ml}$. The yield was approximately $50 \%$. Immunoelectrophoresis established the purity of the isolated albumin (purity \pm 99: Fig. $\mid 1-1)$.

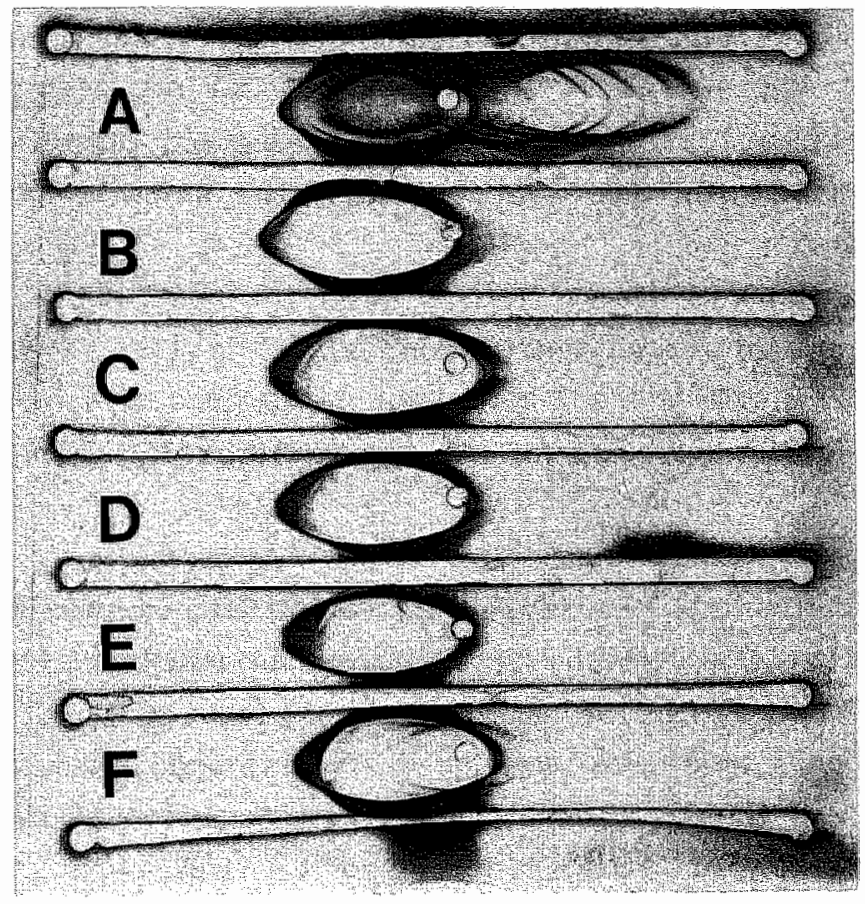

Fig II-1. Immunolectrophoresis of rat serum albumin (RSA) purified from femalo WAG/Rij rats of different ages by DEAE Affi-gel Blue chromatography. Well $A$ contained serum from 3-month-oid fenale WAG/Rij wats. Wells B-E contained RSA isolated from 3-, 12-, 24- and 36-month-old pats, respective1y. Well F contained comercilally availlable RSA (Nordic) (purtity 90.5\%). coat ant-(rat total serum proteins) antiserutn mas used.

Rat serum albumin was iodinated by the method of McFarlane (1956) as modified by Helmkamp et al. (1967) to a final ratio of 1 mole of $125 \mathrm{l} /$ molle of albumin. 
lodinated albumin ( $5 \mathrm{HCi}$ ) was injected into the external jugular vein of rats of the different age groups. Trichloroacetic acid-precipitable radioactivity (using $10 \mathrm{mg} / \mathrm{ml} \mathrm{BSA} ; 1 \mathrm{mg} / \mathrm{ml} \mathrm{KI}$ as a carrier) was determined in $20 \mu l$ of plasma at several time points over 5 days. Blood was sampled from the tail. Radioactivity was directly counted in a $\gamma$-radiation counter.

From the plasma radioactivity curves, in which plasma radioactivity is plotted against the time after injection, the following characteristics were calculated:

a) Elimination half-life: $t_{\frac{1}{2} \text {,el }}$

b) Apparent volume of distribution: $\mathrm{Vd}$

c) Clearance: $\mathrm{Cl}$

These calculations were performed as described by Gibaldi $\&$ Perrier (1975).

The elimination half-life is defined as the time required to eliminate one-half of the total amount of 125 -albumin which is present in the body: $t_{\frac{1}{2}, e l}$ (hours) may be calculated using the equation:

$$
\mathrm{t}_{\frac{1}{2}, \mathrm{e}}=-\frac{\ln 2}{\beta}
$$

$\beta$ is the terminal slope in the plasma radioactivity curve (hours ${ }^{-1}$ ). The elimination half-life is an index of the relative elimination rate.

The apparent volume of distribution (a mathematical concept) is defined as the volume of body water that would be required to contain the amount of ${ }^{125}$-albumin in the body if it were uniformly present in the same concentration as in the plasma. The volume of distribution is termed apparent, since the concentration of $125 /$-albumin may not be the same in all body compartments and only the concentration achieved in the plasma was used in the calculations. Vd $(\mathrm{ml})$ can be calculated as follows:

$$
V d=\frac{D}{-(A \cup C) B}
$$


$D$ is the amount of radio-labeled albumin injected and AUC is the area under the plasma radioactivity curve from time zero to infinity $(\mathrm{cpm} . \mathrm{h} / \mathrm{ml})$. Vd is a proportionality factor which, when multiplied by the 125 -albumin concentration in the plasma, yields the amount of 125 -albumin present in the body. The use of $\mathrm{Vd}$ as a proportionality factor is valid only after the establishment of an equilibrium between the different compartments.

The clearance can be defined as the amount of plasma cleared of 125 -albumin per unit of time. The clearance $(\mathrm{ml} / \mathrm{h})$ can be calculated using the equation:

$$
\mathrm{Cl}=\frac{\mathrm{D}}{\mathrm{AUC}}
$$

The clearance is used as an index for the absolute albumin elimination rate.

3. Plasma albumin concentration, the whole-body albumin pool and the absolute and fractional rate of albumin elimination

The albumin concentration in plasma was determined by radial immunadiffusion, as described by Mancini et al. (1965) and modified by Radl et al. (1970). With the use of the plasma albumin concentration. the data for apparent volume of distribution and clearance can be extrapolated in terms of the whole-body albumin pool and the absolute and fractionall rates of albumin elimination. The whole-body albumin pool ( $\mathrm{mg}$ ) can be calculated using the equation:

$V d \times$ plasma albumin concentration

The absolute rate of albumin elimination ( $\mathrm{mg} / 24 \mathrm{~h}$ ) can be calculated using the equation:

$\mathrm{Cl} \times$ plasma albumin concentration $\times 24$

The fractional rate of albumin elimination $\left(\frac{c}{2} / 24 \mathrm{~h}\right)$ is the absolute 
rate of albumin elimination expressed as a percentage of the wholebody albumin pool per day. It can be calculated using the equation:

Absolute rate of albumin elimination $\times 100$

Whole-body albumin pool

\section{1-3. RESULTS}

II-3a. Plasma radioactivity curves

Pliasma clearance situdies were performed in each rat of the respective age-groups with two different allbumins. Firstly, each rat was injected intravenously with albumin isolated from 3-month-old rats, so that any age-related changes in the elimination of this albumin preparation were due entirely to physiological changes in the animal. Secondly, the same rats were injected intravenously with albumin isolated from rats of the same age as the recipient. This appraach therefore revealed age-related changes in the elimination of albumin due to a combination of physiological changes in the animal and any changes in the albumin moleculle.

Plasma radioactivity curves were constructed after injection of al-bumin isolated from 3-month-old ratsinto rats of the four age-groups. Fig. II-2 shows the mean plasma radioactivity curves which were obtained, by plotting semilogarithmically the TCA-precipitable counts per $\mathrm{ml}$ of plasma against the time after injection. From the individual plasma radioactivity curves, the ellimination half-life, the apparent volume of distribution and the clearance were calculated. Age-related changes in these three characteristics are shown in Table $11-1$. Although there are no major age-related changes in the elimination halflives for albumin, the values for clearance and apparent wolume of distribution are higher at 24 months of age than at 3 and 12 months of age but by 36 months of age, only the clearance is significantly higher than that observed at 3 months of age.

Mean plasma radioactivity curves for the four age-groups obtained after injection of age-matched albumin are shown in Fig. II-3. 


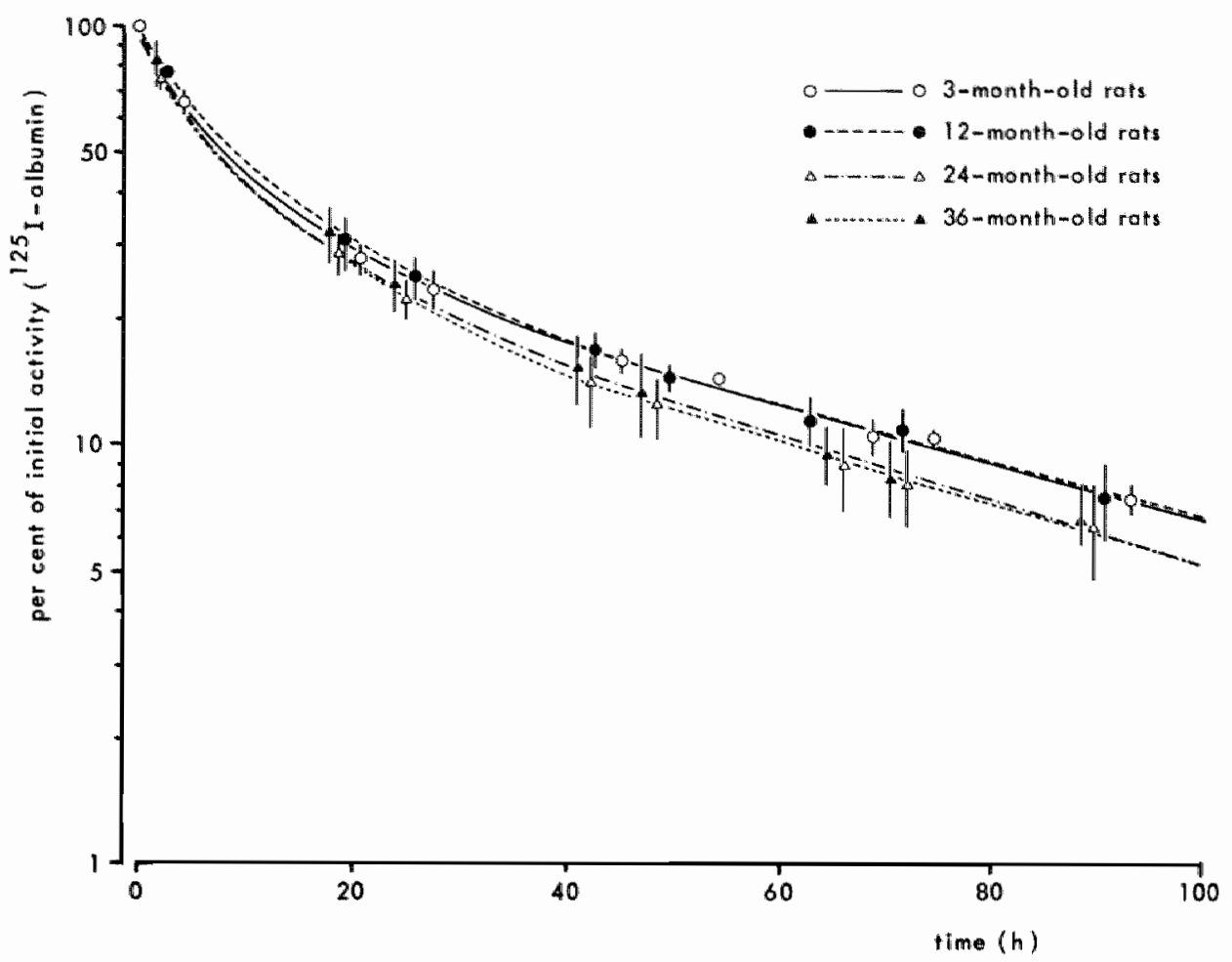

Fig. 11-2. Mean plasma radiaactiwity curves abtained after injection of albumin isolated from 3 -month-old rats into groups of rats of different ages. TCA-precipitable radioactivity per mi of plasma at time zero was extrapolated from deterninations after 2,3 and 5 min and was designated as 100\%. The values represent the means \pm S.D. for a min nimum of six experiments.

The characteristics calculated from the individual plasma radioactivity curves are shown in Table $11-1$. Again, no significant age-related changes in elimination half-lives of these albumins are observed. The values for clearance and apparent volume of distribution are higher at 24 and 36 months of age than those at 3 and 12 months of age. In contrast with the results obtained from clearance studies with albumin isolated from 3-month-old rats, higher values for apparent volume of distribution and clearance for animals aged 36 months are observed compared with what is observed in the 24-month-old animals. 


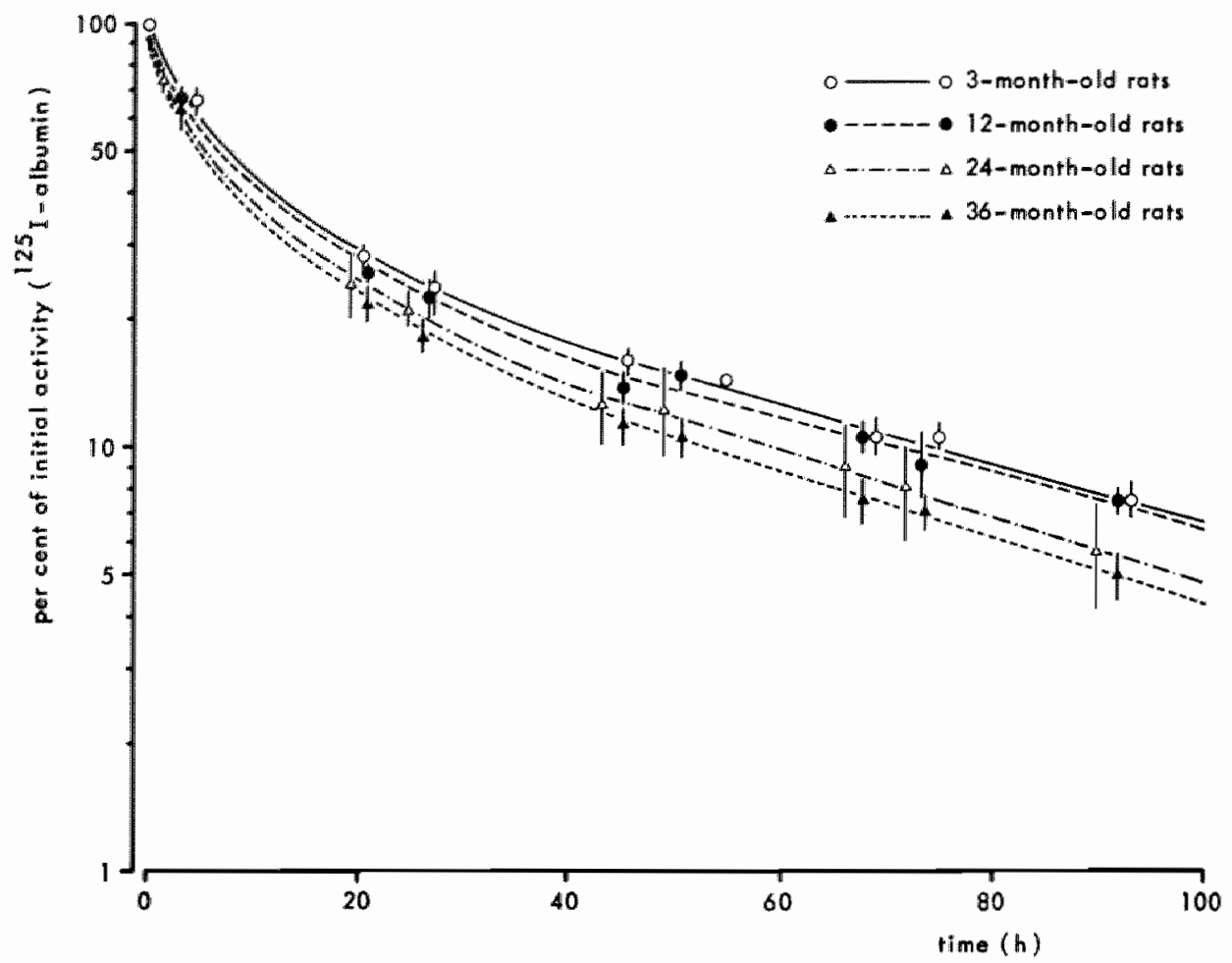

Fig. 11-3. Mean plasma radioactivity curves obtained in groups af rats af different ages when injected with albumin isolatied from rats of the same age as the recipient. The values represent the means $t$ S.D. for a minimum of six experiments.

The influence of the age of the albumin-donor-rats on $t_{\frac{1}{2}}, e l^{\prime}, \mathrm{Vd}$ and $\mathrm{Cl}$ in other recipients can be deduced from the data shown in Table 1I-1. An influence of the age of the albumin-donor-rats on these three characteristics could only be observed in 36-month-old recipients. Higher values for apparent volume of distribution and clearance were found in this age-group after administration of agematched albumin than after administration of albumin isolated from 3month-old animals. In the rats of the other three age groups, no differences in these characteristics could be observed when albumin 


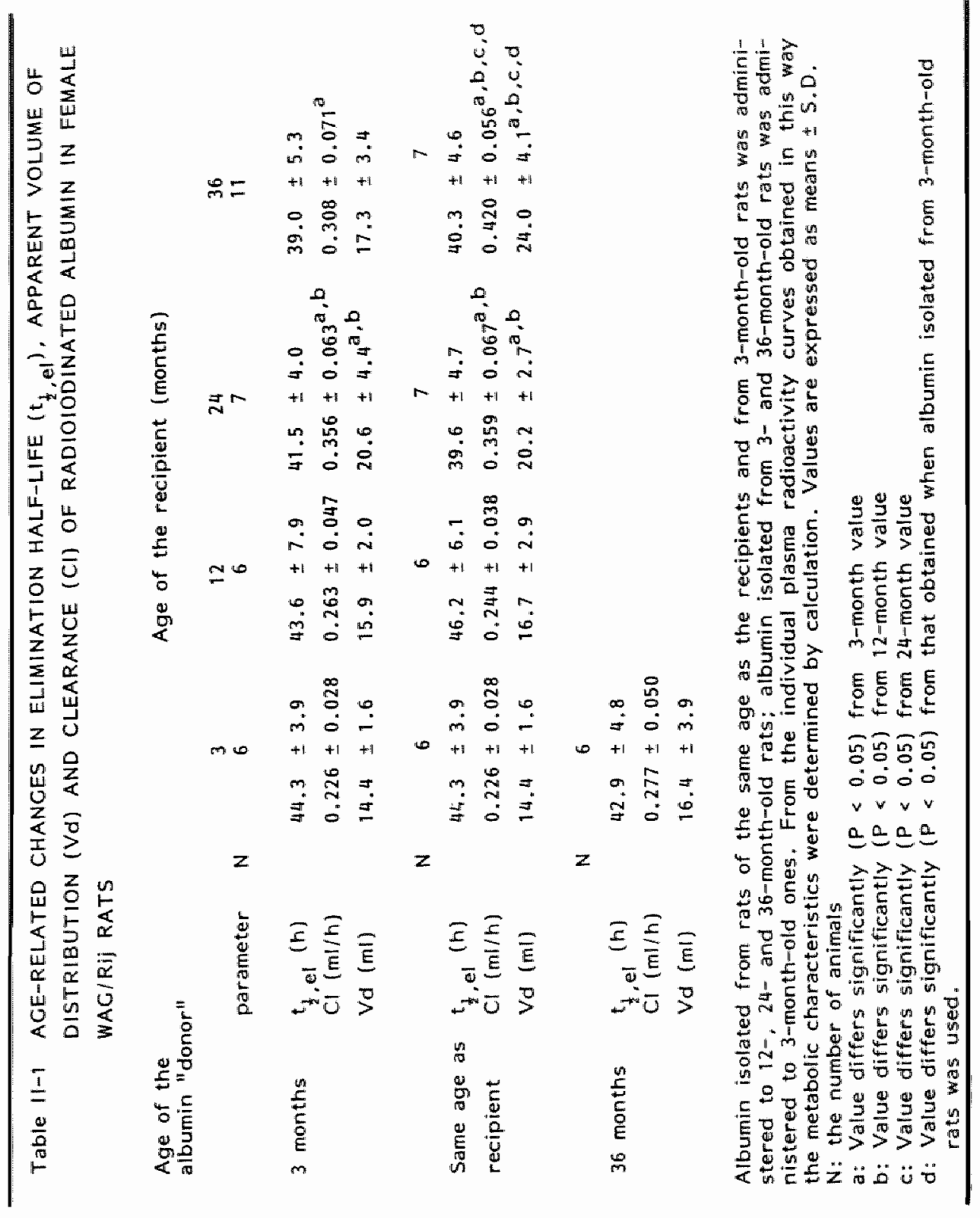


isolated from rats of another age-group was administered.

11-3b. Albumin concentration in the plasma, the whole-body albumin pool and the absolute and fractional rate of albumin elimination

Plasma albumin concentrations were determined in the same rats as were used for the construction of the plasma radioactivity' curves. The results are given in Table $11-2$. No significant changes in the plasma albumin concentration with age can be seen.

From the values obtained for clearance, apparent volume of distribution and plasma albumin concentration, values for the whole-body albumin pool and the absolute and fractional rate of albumin elimination could all be calculated. Since the results showed that the clearance and apparent volume of distribution are influenced by the age of the albumin donor rats in 36-month-old recipients (Table 11-1), the calculations were carried out only on data obtained with age-matched albumin.

The results are shown in Table $11-2$. No significant changes in the fractional rate of albumin elimination with age can be seen. However, the values for the whole-body albumin pool and for the absolute rate of albumin elimination were higher at 24 months of age than at 3 and 12 months of age, and at 36 months of age than in any of the other groups.

\section{II-4. DISCUSSION}

The work reported here shows age-related changes in the absolute albumin elimination rate in female $\mathrm{WAG} / \mathrm{Rij}$ rats. The experiments were designed to determine whether changes in albumin elimination were due to changes in the physiology of the animal and/or to changes in the albumin molecule itself.

After injection of albumin isolated from rats of the same age as the recipient, the clearance was found to change with age. The value for 


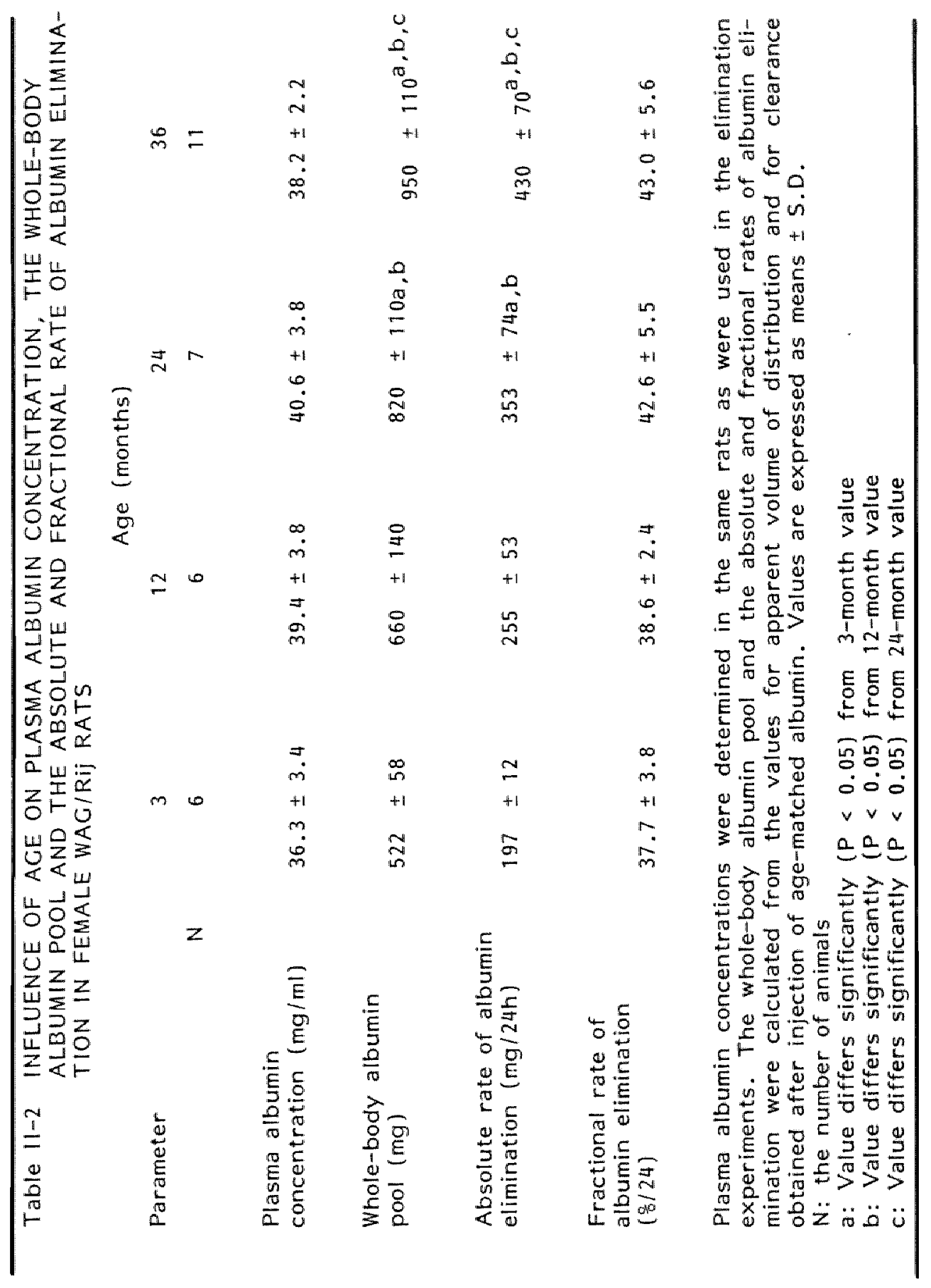


clearance observed at 36 months of age was higher than that at 24 months of age, which in turn was higher than that at 12 months of age (Table $\mid 1-1$ ). However, no age-related change in elimination half-life for albumin was seen. This observation is in agreement with the results on elimination half-lives published by Salatka et al. (1971) and by Ove et al. (1972). Concomitant with the increase in clearance with age, an increase in apparent volume of distribution was seen. Since the plasma albumin concentration was constant throughout the lifespan of female WAG/Rij rats, the increase in apparent volume of distribution reflected an increase in the wholle-body albumin pool (Table 11-2). After injection of albumin isolated from 3 -month-old rats into the animals of each age-group, no increase in clearance was found between 24- and 36-month-old rats. The increase in albumin clearance between 12- and 24-month-old rats, however, was still present (Table 11-1).

Furthermore, rats of 12 and 24 months of age cleared albumin isolated from rats of their own age in the same way as they did the albumin derived from the 3-month-old ones (Table 11-1). These observations indicate that the increase in albumin elimination between 12- and 24month-ald rats was not caused by a change in the albumin molecule but by some change-in the physiology of the animal.

The higher value for the absolute elimination rate of albumin in 36month-old rats compared to that in 24-month-old ones (Table 11-2) might be due to changes in the albumin molecule during this time interval. However, since 3 -month-old rats showed only a tendency to eliminate the albumin isolated from 36 -month-old ones in a way different to the elimination of their own albumin $(P<0.10)$, a change in the albumin molecule of 36 -month-old rats could not be the sole cause of the change in absolute albumin elimination rate between the ages of 24 and 36 months (Table $\| 1-1)$.

This study showed an age-related increase in total albumin elimination. Whether or not this is due to some specific albumin elimination process will be addressed in the next chapter. 


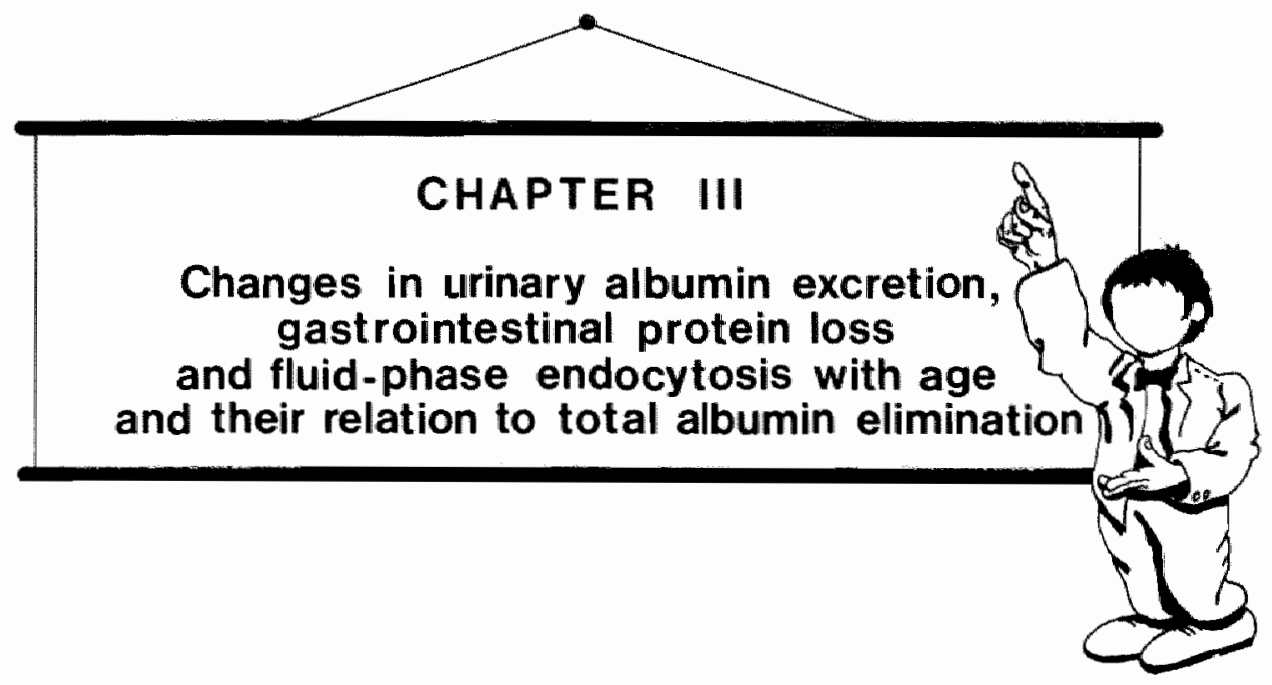

III-1. INTRODUCTION

The total elimination of albumin in female WAG/Rij rats is dependent upon the age of the animals (Horbach et al., 1983; Chapter 11). An increase in albumin elimination occurs between 12 and 36 months of age. It has also been shown that the increase which occurs between 12 and 24 months of age is predominantly due to a change in the animal's physiology, while between 24 and 36 months of age, changes in the albumin molecule are also important in producing this change in albumin elimination. This chapter will deal with the influence of age on three main albumin elimination processes: urinary albumin excretion. gastrointestinal protein loss and fluid-phase endocytosis, and their relation to the changes in total albumin elimination in rats.

An increased loss of albumin in the urine has been observed in many rat strains as the animals age (Beauchene et al., 1970; Obenra- 
der et all., 1974a; Alt et al, 1980). Albumin excretion via the urine was increased in male and female Wistar rats from $36.6 \pm 6.9$ at 11-14 months of age to $111.3 \pm 22.2 \mathrm{mg} /$ day at $23-38$ months of age (Beauchene et al., 1970): in female Fischer rats from $0.59 \pm 0.03$ at $4-6$ weeks of age to $3.10 \pm 0.26 \mathrm{mg} /$ day $/ 100 \mathrm{~g}$ rat at $17-20$ months of age (Obenrader et al. 1974a); and in male Han:Wistar rats from $0.015 \pm$ 0.006 at 5.5 months of age to $3.048 \pm 2.027 \mathrm{mg} / \mathrm{h} / \mathrm{kg}$ body weight at 38 months of age (Alt et al.. 1980). Beauchene et al. (1970) suggested that the increase in albumin synthesis with age was a compensatory mechanism for the increased urinary excretion of albumin. However, Obenrader et al. (1974a) demonstrated that albumin synthesis was not regulated to any great extent by the rate of albumin excretion in to the urine.

The loss of plasma proteins via the gastrointestinal tract has been described as a pathological cause of increased albumin catabolism in humans (Van Tongeren, 1967; Wochner et all., 1968). An increase in gastrointestinal protein loss could be caused by an increased permeability of the intestinal mucosa or by a direct leakage as a result of lymphatic obstruction (Steinfeld et al., 1960; Jeffries et al., 1962; Van Tongeren, 1967).

Fluid-phase endocytosis is a non-specific process of cell surface invagination by which extracellular solutes are transported into the cell and may account for as much as one-half of the catabolism of albumin in rats (Munniksma et al. 1980). It has been suggested that this process has a physiological role in the delivery of plasma proteins to the lysosomes and thus providing amino acids for cellular protein synthesis. Since adsorption on the pllasma membrane is not included in fluidphase endocytosis, this latter process accounts for the minimum rate of albumin elimination (Ehrenreich $\&$ Cohn, 1967; Besterman et al., 1983). 
111-2a. Animals and materials

For determination of urinary albumin excretion and gastrointestinal protein loss, the female WAG/Rij rats, which were used to assess the total albumin elimination (Chapter II) were used. For the measurement of fluid-phase endocytosis, new groups of 3-, 12-, 24- and 36-monthold animals were used. The mean weights $[ \pm$ S.D. $)$ for these groups were $147 \pm 6,184 \pm 9,236 \pm 14$ and $224 \pm 18 \mathrm{~g}$, respectively.

${ }^{51} \mathrm{CrCl}_{3}$ and ${ }^{125}$ /-labeled polyvinylpyrrolidone were obtained from the Radiochemical Centre (Amersham, Bucks, UK) and rabbit anti-(rat serum albumin) antiserum (RARa/Alb) was obtained from Nordic Immunological Laboratories (Tilburg. The Netherlands). Other chemicals of a high grade were obtained from standard chemical suppliers.

I11-2b. Assays

1. Urinary albumin excretion

Animals were kept in metabolic cages for 24 hours and supplied with water and food ad libitum. The urine was collected and the amount of albumin excreted was determined by radial immunodiffusion as described by Mancini et al. (1965) and modified by Radl et al. (1970).

\section{Gastrointestinal protein loss}

Protein loss through the intestinal wall was determined by using the ${ }^{51} \mathrm{CrCl}_{3}$-method described by $\mathrm{Van}$ Tongeren 8 Reichert (1966). Briefly. ${ }^{51} \mathrm{CrCl}_{3},(5 \mu \mathrm{Ci})$ was injected intravenously into the external jugular vein of rats of the four age-groups. These rats were kept in metabolic cages to permit collection of the faeces. Radioactivity was determined in $20 \mu \mathrm{l}$ samples of plasma at several time points over 30 hours. At time $T( \pm 24$ hours after injection $), 25 \mathrm{mg}$ of Carmine was administered 
orally to the rats as a faeces marker. This time point was chosen since it lies on the elimination-phase of the plasma radioactivity curve of ${ }^{51} \mathrm{CrCl}_{3}$. Radioactivity in the faeces was determined until the appearance of the marker. Gastrointestinal clearance (Cl gastro) was calculated by the quotient of radioactivity in the faeces and the area under the plasma radioactivity curve from zero time to time $T$.

\section{Fluid-phase endocytosis}

\section{- Plasma radioactivity curves}

125 -labeled PVP $(5 \mu \mathrm{Ci})$ was injected into the external jugular vein of rats of the four age groups. Blood was sampled from the tail at 3 , 5, 10, 15, 30, 45 and 60 minutes after injection, followed by 15 additional samples at intervals of $1-2$ hours up to 28 hours after injection. Radioactivity in $20 \mu \mathrm{l}$ samples of plasma was counted directly in a $\gamma$-radiation counter.

\section{- Measurement of total radioactivity in organs and tissues}

Rats were killed by over-anaesthetizing with ether at 28 hours after injection of ${ }^{125}$ I-PVP. After the organs had been removed, the skin was depilated, removed, freed of fat and then weighed. Portions were taken and the radioactivity determined. All the muscles of the posterior thigh were removed and weighed. The total muscle mass in 3month-old rats was calculated as $45 \%$ of the body weight (Keeler. 1970). In 12-. 24- and 36-month-old rats this factor was corrected for changes in the muscle/body weight ratio with age due to e.g. atrophy of the muscles with age or an increased fat content of the body. This correction was calculated by considering the decrease in the weight of the muscles of the posterior thigh per $100 \mathrm{~g}$ of total body weight as representative. In 12 -month-old rats the mean muscle mass was found to be $45 \%$ of the total body weight (range $=428-46 \%$ ), and in $24-$ and 36 -month-old animals this mean value was $34 \%$ (range $=25 \%-399)$. In 
calculating the whole muscle mass for the animals of these three agegroups, the values for individual animals were used.

The liver, kidneys, lungs, heart, spleen and small intestine were removed intact, thoroughly washed with $0.9 \% \mathrm{NaCl}$, weighed and minced with scissors. Radioactivity was measured in several weighed portions.

Total radioactivity in liver, kidneys and spleen was corrected for the amount of radioactivity in the residual plasma present in these organs at the time of sampling (as described by Munniksma et all., 19801.

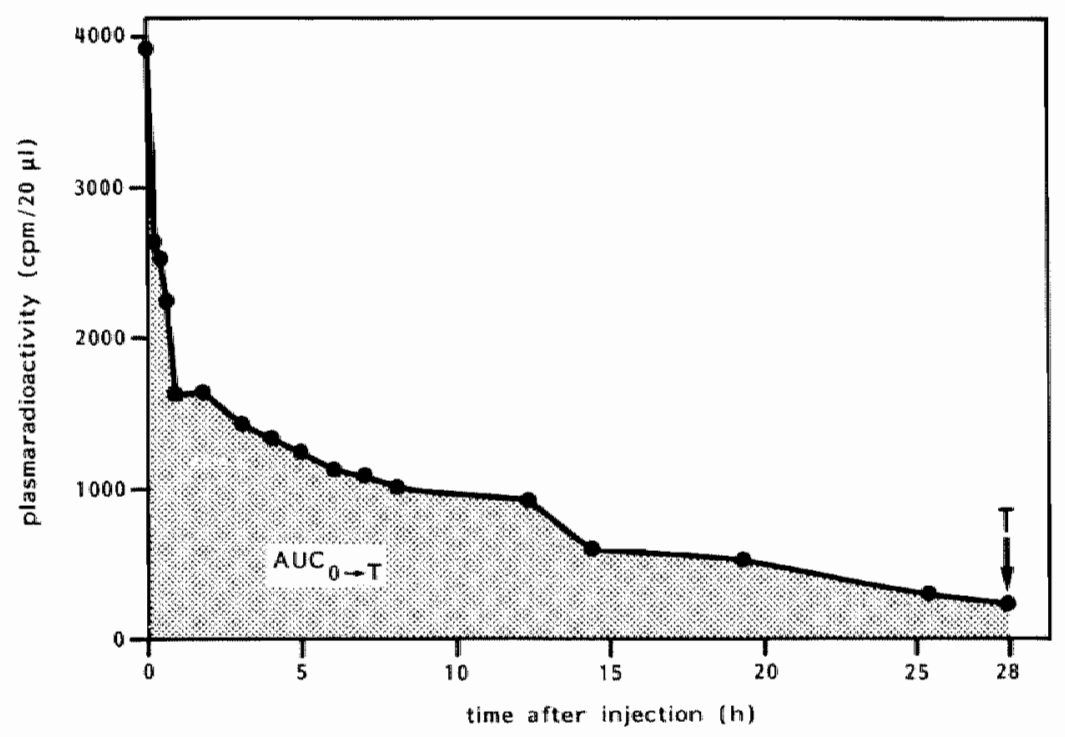

Fig. IIll-1. Plasma radioactivity curve obtained after intravenous injection of 125 labeled polyvinylpyrrolidone into a femalle WAG/Rij rat of 3 months of age. The area under the plasma radioactiwity curve from zero time to $28 \mathrm{~h}$ $\left(A \cup C_{0-28 h}\right)$ was determined by the trapezoid rule.

- Calculations

Rates of fluid-phase endocytosis in organs or tissues for ${ }^{125}$ |-labeled PVP were calculated by

$$
\frac{\mathrm{cpm} \text { (organ/tissue) at time } \mathrm{T} \times 24}{\mathrm{AUC}_{0-\mathrm{T}}}(\mathrm{ml} / \mathrm{day})
$$


where "cpm (organ/tissue) at time $T$ " is the total radioactivity found in the organ or tissue at the time of killing (T), and $A \cup C_{0-T}$ is the area under the plasma radioactivity curve from zero time to time $T$ (cpm.h / ml), (Fig. IIl-1), (Gibaldi \& Perrier, 1975; Horbach et al., 1984b; Horbach et al., 1986b). These calculations were performed by assuming that exocytosis of PVP is negligible during the first day after injection (Munniksma et al., 1980).

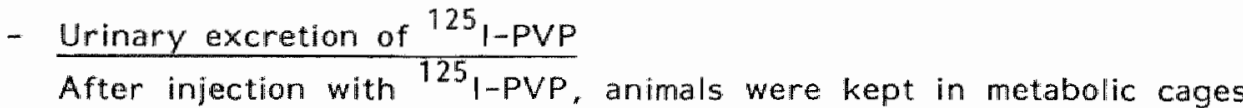
for 28 hours and supplied with water and food ad libitum. The urine was collected and the amount of $125_{1}$-PVP excreted was determined.

Table III-1* THE INFLUENCE OF AGE ON THE ABSOLUTE RATE OF ALBUMIN ELIMINATION AND URINARY ALBUMIN EXCRETION IN FEMALE WAG/RIj RATS.

\begin{tabular}{|c|c|c|c|}
\hline $\begin{array}{l}\text { Age } \\
\text { (months) }\end{array}$ & $\begin{array}{l}\text { Absolute rate } \\
\text { of albumin } \\
\text { elimination } \\
(\mathrm{mg} / 24 \mathrm{~h})\end{array}$ & $\begin{array}{l}\text { Urinary } \\
\text { albumin } \\
\text { elimination } \\
\text { mg }(24 \mathrm{~h})\end{array}$ & $\begin{array}{l}\text { Urinary excretion } \\
\text { as percentage of } \\
\text { absolute elimina- } \\
\text { tion rate }\left(\frac{8}{8}\right)\end{array}$ \\
\hline 3 & $197 \pm 12(6)$ & $0.22 \pm 0.08(6)$ & $0.1 \pm 0.1(6)$ \\
\hline 12 & $255 \pm 53(6)$ & $0.20 \pm 0.11(6)$ & $0.07(6)$ \\
\hline 24 & $353 \pm 74^{a, b}(7)$ & $2.4 \pm 1.4^{\mathrm{a}, \mathrm{b}}$ (7) & $0.5^{a, b}(7)$ \\
\hline 36 & $430 \pm 70^{a, b, c}(11)$ & $16 \pm 16^{a, b, c}(6)$ & $2.4 \pm 1.9^{a, b, c}(6)$ \\
\hline
\end{tabular}

Urinary albumin excretion was determined by radial immunodiffusion in the same rats as were used in the elimination experiments described in Chapter 1I. Absolute rates of albumin elimination were determined in the experiments described in Chapter II. Values are expressed as means \pm S.D. Numbers of animals are given in parentheses. a: value differs significantly $(p<0.05)$ from 3 -month-value. $b$ : value differs significantly $(p<0.05)$ from 12 -month-value. c: value differs significantly $(p<0.05)$ from 24 -month-value. 
111-3a. Urinary excretion of albumin

The amount of albumin excreted in the urine was determined in 3- . 12-, 24- and 36-month-old female WAG/Rij rats. The results are presented in Table $111-1$. These data on albumin excretion in the urine show an increase with age. However, when the urinary albumin excretion is compared with the total albumin elimination, it can be seen

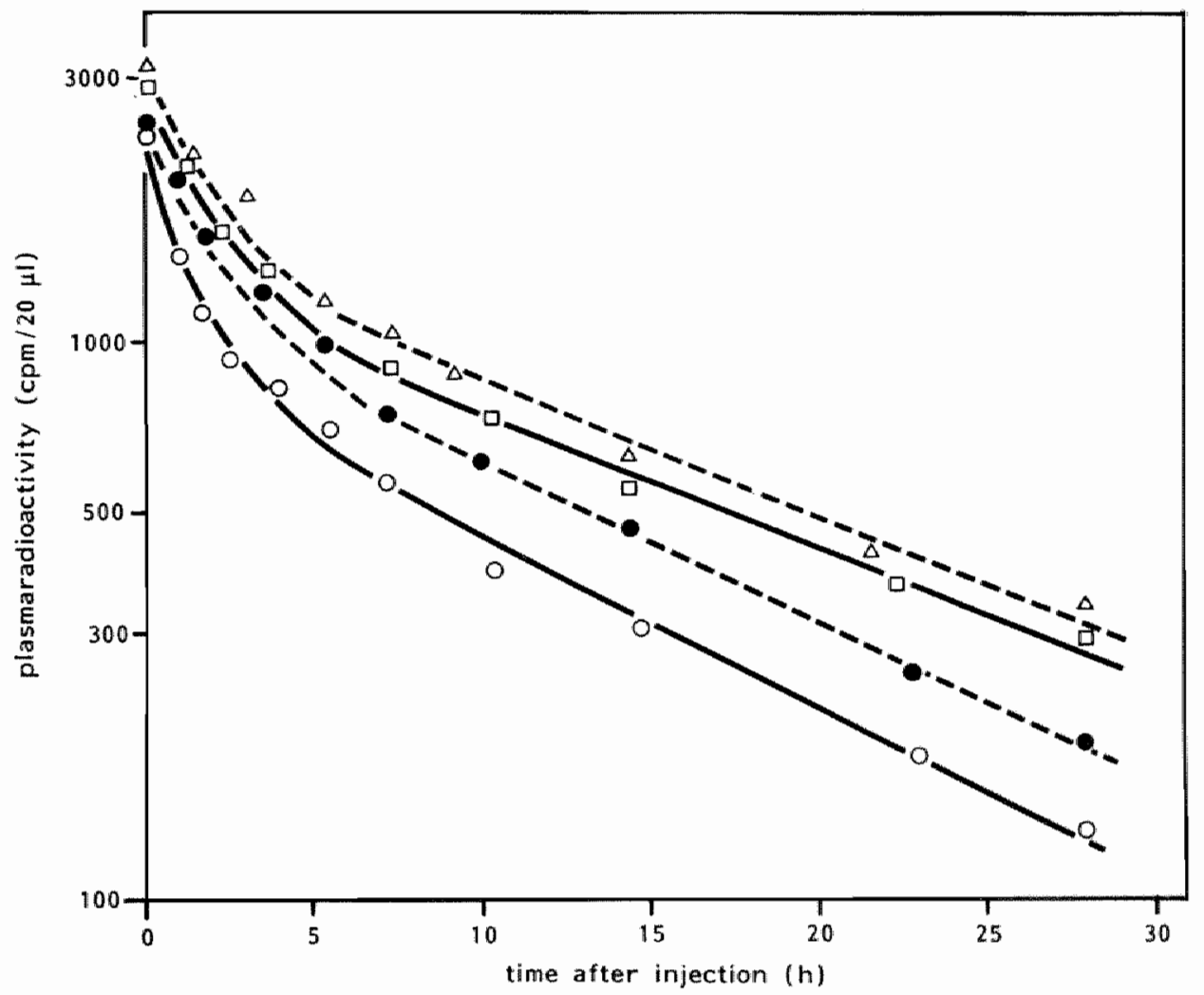

Fig. $111-2$. Mean plasma radioactivity curves obtained after intrawenous injection of ${ }^{51} \mathrm{CrCl}_{3}$ into female WAC/Rij rats of different ages. The walues represient the means for at least 6 experiments. The standard devition was always less than 15\%. (回) $3-,(0) 12-$, (a) $24-$ and $(\Delta) 36$-month-old rats. 
that the urinary excretion accounts for only $0.1-2.49$ to the total elimination of albumin in these rats (Table \|\|$-1)$.

III-3b. Gastrointestinal protein loss

Protein loss through the intestinal wall was determined in rats of the four different age-groups by using the ${ }^{51} \mathrm{CrCl}_{3}$-method. Mean plasma radioactivity curves are illustrated in Fig. III-2. The individual curves were used for calculation of gastrointestinal protein loss. The results of these calculations are given in Table $|1|-2$.

No significant age-related change in gastrointestinal protein loss was seen.

Table \|\| $1-2$ INFLUENCE OF AGE ON THE GASTROINTESTINAL CLEARANCE (Cl gastro) OF PLASMA PROTEINS

Age

(months)

3

12

24

36
N

7

7

6

6
$\mathrm{Cl}$ gastro

$(\mathrm{ml} / \mathrm{h})$

$0.161 \pm 0.062$

$0.184 \pm 0.084$

$0.130 \pm 0.035$

$0.113 \pm 0.021$

Values are expressed as means $\pm S . D$.

$N$ : the number of animals 
- Plasma radioactivity curves

Plasma clearance of ${ }^{125} 1$-PVP was studied in each rat of the different age-groups. Plasma radioactivity was plotted semilogarithmically against the time after injection. Fig. $111-3$ shows the mean plasma radioactivity curves for the four age-groups.

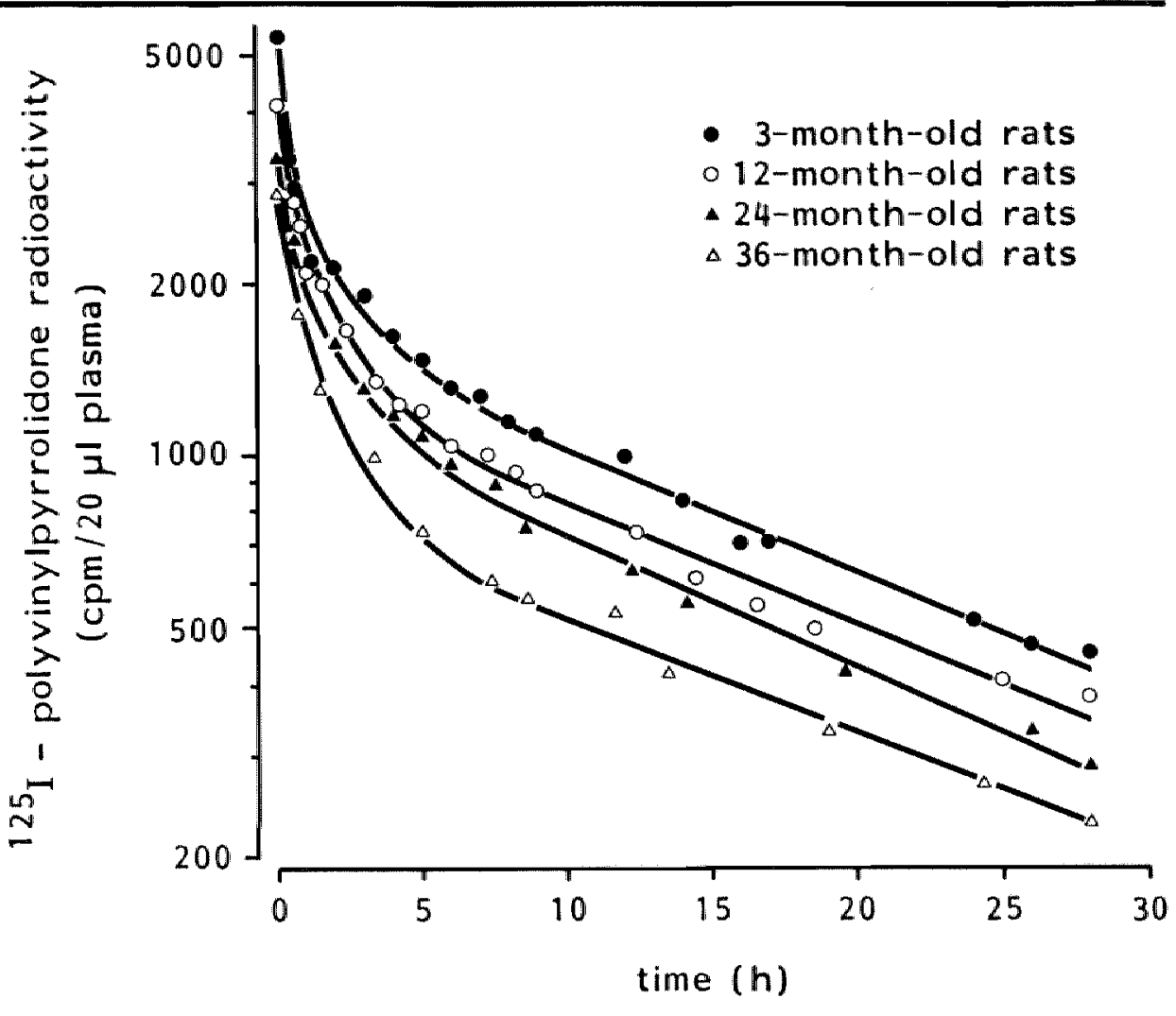

Fig. III-3. Mean plasma radioactiwity curwes obtained after injection of 125 1-1abeled polyvinylpryrrolidone into female WAG/Rij rats of different ages. The values represent the means for at least flve experiments. The standard deviation was always less than $10 \%$.

As can be seen from this figure, an age-related decrease in the mean area under the curve $(0-28 \mathrm{~h})$ was observed. From the individual plas- 
ma radioactivity curves the "area under the curve" (AUC $C_{0-T}$ ) was calculetted and was used for the determination of the ${ }^{125}$ I-PVP clearance by organs and tissues.

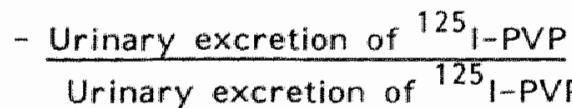
tion of the amount of ${ }^{125}$ I-PVP of, especilally, the low-molecular weight form which passes the glomerulf and is therefore excluded from fluid-phase endocytic processes. In all age-groups examined, no change in 125 1 -PVP excretion was observed. The amount excreted in 28 hours was approximately 35 of of the dose.

- 125 I-PVP clearance by organs and tissues

Rates of fluid-phase endocytosis ( $\mathrm{ml}$ of plasma cleared of PVP/organ or tissue per day) were calculated as described in section 1ll-2b.3. The results are shown in Table $111-3$. It is clear that the liver exhibits a high level of ${ }^{125}$ I-PVP uptake as do skeletal muscle and skin, regardless of the age of the animals.

Up to 12 months of age, no change in the level of ${ }^{125}$ 1-PVP clearance per organ or tissue is seen. Between 12 and 24 months of age, an increase in 125 -PVP clearance occurs in the small intestine, the kidneys, the lungs and the skin. Between 24 and 36 months of age, an increase in fluid-phase endocytosis was also observed. Between these two ages, the relative contribution by the liver and the muscles to this increase is especially noteworthing.

When expressing the fluid-phase endocytic rate per gram of organ or tissue, the high activity of the spleen can be seen (Table 111-4). Muscle and skin exhibit very low endocytosis per gram tissue. Except for the kidneys and skeletal muscle, no age-related changes in endocytosis per gram of organ or tissue can be found. This suggests that the increase in fluid-phase endocytosis by organs and tissues with age is mainly due to an increase in the wet weight of these organs and tissues and only to a limited extent to a change in specific activity. 


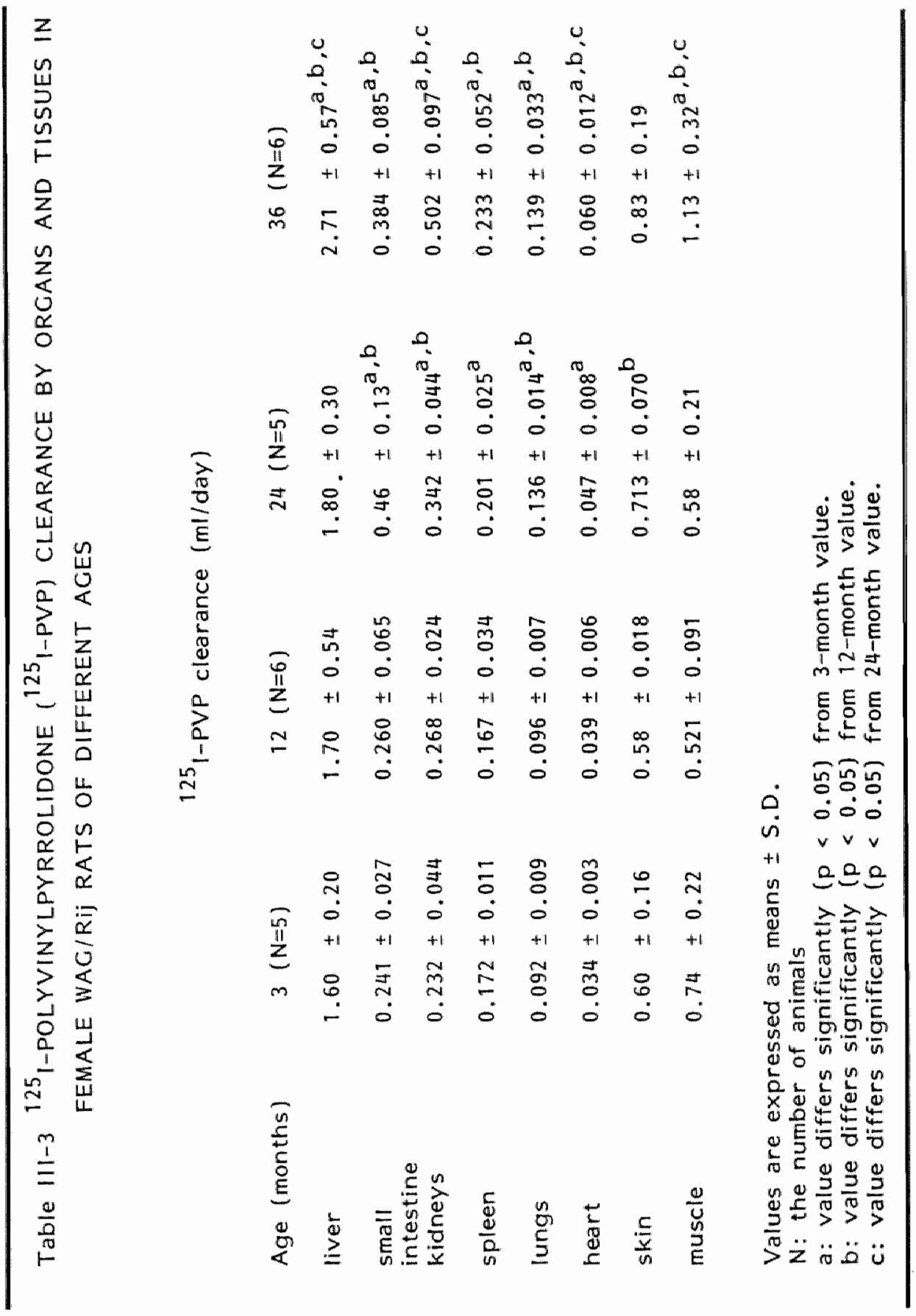




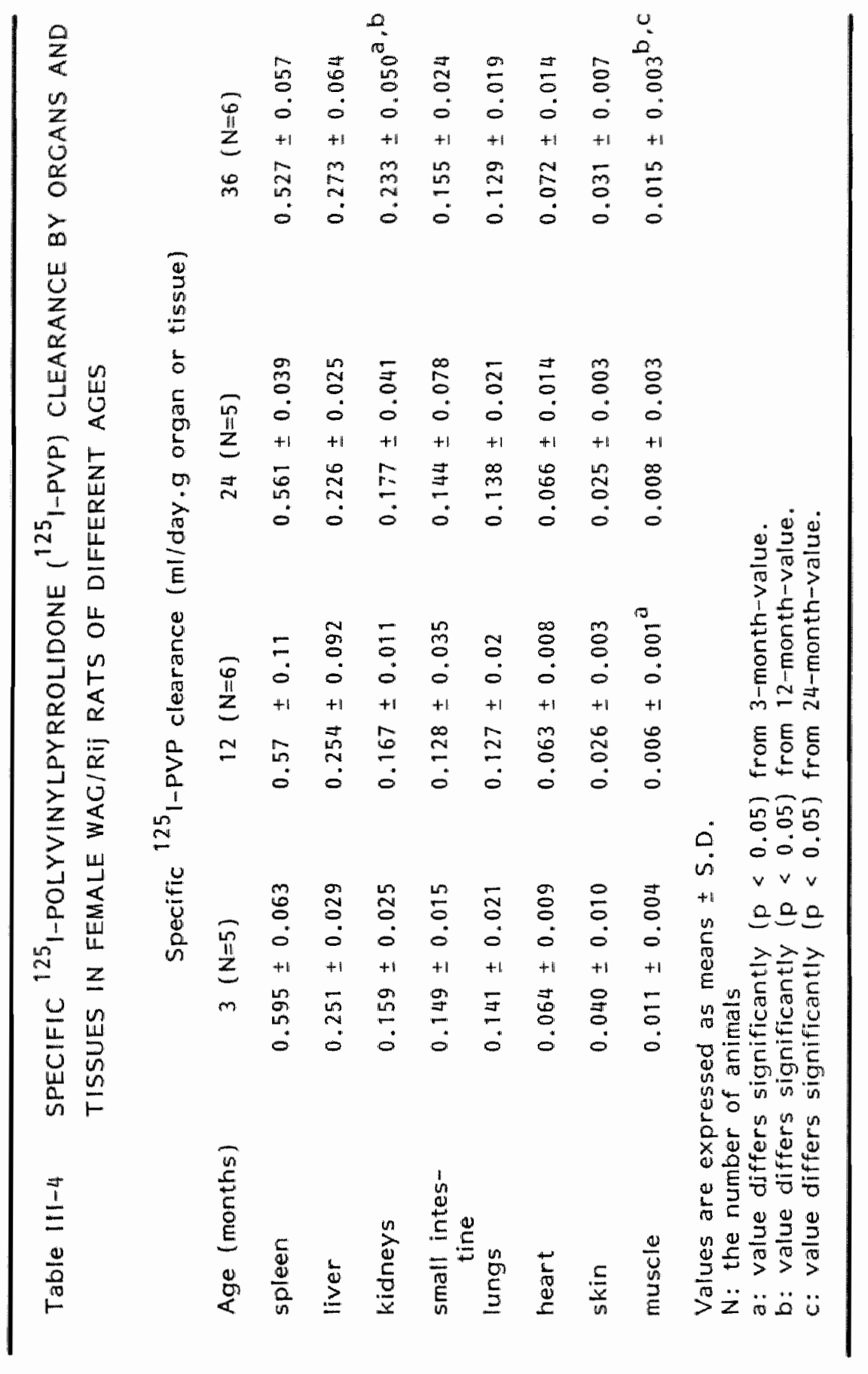


In order to determine whether some specific albumin elimination process is responsible for the observed age-related increase in the total albumin elimination rate in rats, studies were performed on the influence of age on urinary albumin excretion as well as two other possible causes of plasma protein loss: namely, protein loss through the gastrointestinal wall and fluid-phase endocytosis.

Table $\| 1-1$ shows an increase in urinary albumin excretion between the ages of 12 and 24 months, and between 24 and 36 months. The agerelated changes in the absolute albumin elimination rate could not be attributed to this increase in urinary albumin excretion since it was calculated that even the highest excretion rate at 36 months of age accounts for only 2.48 of the total elimination of albumin in the old rats. Therefore, since the old rats were able to eliminate up to 988 of the injected albumin via mechanisms other than urinary excretion, it could be concluded that the increase in albumin excretion in the urine in the female WAG/Rij rats was not the trigger for the increase in albumin synthesis with age as suggested by Beauchene et al. (1970).

Loss of protein through the gut wall could also influence albumin elimination. Table $|I|-2$ shows the influence of age on the gastrointestinal protein loss. It can be seen that the gastrointestinal clearance remained constant with age. However, in this experiment, no direct estimation of the albumin clearance through the intestinal wall could be made. After injection of ${ }^{51} \mathrm{CrCl}_{3}$, albumin and transferrin are labeled. transferrin more than albumin. Changes in ${ }^{51} \mathrm{Cr}$ clearance may only be extrapolated to changes in albumin clearance when it is demonstrated that no distinction is made between the two proteins by the intestinal wall during leakage (van Tongeren \& Reichert, 1966).

A number of markers have been used to study the rate of fluidphase endocytosis in different organs or tissues (Pratten et al., 1980). The requirements for a good marker are that it should not show any adsorption to the plasma membrane and that it should have the same 
Table $111-5$

THE INFLUENCE OF AGE ON THE CONTRIBUTION OF

FLUID-PHASE ENDOCYTOSIS TO TOTAL ALBUMIN

ELIMINATION IN FEMALE WAG/RIj RATS

\begin{tabular}{|c|c|c|c|c|c|}
\hline $\begin{array}{c}\text { Age } \\
\text { (months) }\end{array}$ & $\begin{array}{l}\text { Albumin elimi } \\
\text { by fluid-phas } \\
\text { endocytosis } \\
\text { (mg/24h) }\end{array}$ & ration & $\begin{array}{l}\text { Total albumin } \\
\text { elimination }\end{array}$ & & $\begin{array}{l}\text { Percentage } \\
\text { cleared by } \\
\text { fluid-phase } \\
\text { endocytosis } \\
\left(\frac{o}{5}\right)\end{array}$ \\
\hline 3 & $90 \pm 10$ & (5) & $197 \pm 12$ & $(6)$ & $\pm 6(5)$ \\
\hline 12 & $98 \pm 12$ & (6) & $255 \pm 53$ & $(6)$ & $\pm 9(6)$ \\
\hline 24 & $121 \pm 10^{a, b}$ & (5) & $353 \pm 74^{a, b}$ & $(7)$ & $\pm 7(5)$ \\
\hline 36 & $161 \pm 19^{a, b}$, & (6) & $430 \pm 70^{a, b}, c$ & (11) & $\pm 7(6)$ \\
\hline
\end{tabular}

Albumin elimination by fluid-phase endocytosis was calculated by multiplying plasma albumin concentration and PVP clearance (of all organs/tissues examined except skin and muscle). Plasma albumin concentrations and total albumin elimination were determined in the experiments described in Chapter 11 . Values are expressed as means \pm S.D. Number of animals are given in parentheses.

a: value differs significantly $(p<0.05)$ from 3-month-value.

$b$ : value differs significantly $(p<0.05)$ from 12 -month-value.

$c$ : value differs significantly $(p<0.05)$ from 24 -month-value.

rate of uptake as other ideal substances taken up by fluid-phase endocytosis alone, which will be lower than for any other substance which is adsorbed (Roberts et al., 1977).

PVP is a metabolically stable compound which fullfils these requirements (Roberts et al., 1977; Duncan \& Lloyd, 1978). Using this marker. Munniksma et al. (1980) investigated fluid-phase endocytosis in several organs and tissues of male Wistar rats. High levels of fluid-phase endocytosis were found in the liver, skin. skeletal muscle and spleen. When this uptake was expressed per unit weight of argan 
or tissue, they found the spleen to be the most active organ fin fluidphase endocytosis. The results presented in this chapter are consistent with these results (Table $\| 1-3$ and \|\|$-4)$. The high uptake of 125 1 -PVP in muscle and skin is explained by the relativelly large contribution these tissues make to the total body mass (Table $\|1\|-3$ ).

Baynes and Thorpe (1981) reported a high uptake of albumin in skeletal muscle and skin in the rat. However, only a very small proportion of the albumin "taken up" in these tissues had been degradled when assessed at 18 hours after the injection of labeled albumin. The degradation gradually increased up to $70 \%$ over 4 days. Since endocytosis is thought to be directly linked to degradation in the lysosomes (Ehrenreich \& Cohn, 1967; Besterman et al., 1983; Besterman \& Low, 1983), the high recovery of undegraded albumin in muscle and skin in the first few days after injection is more likely due to the presence of this labeled protein in extracellular fluid las suggested by Munniksma et al., 1980) rather than to fluid-phase endocytosis. The findings of Baynes and Thorpe (1981) and Munniksma et al. (1980) suggest that skin and muscle play a less important role in the clearance of ${ }^{125} 1-P V P$ than the results illustrated in Table \|\|$-3$ would suggest.

Our results show an increase in ${ }^{125}$ I-PVP uptake both between 12 and 24 months of age and between 24 and 36 months of age (Table $(11-3)$. The increase between 12 and 24 months of age is due to the small intestine, the kidneys and the lungs. Between 24 and 36 months of age the increase was caused by the liver, kidneys and heart. Except for the kidneys, which showed a higher specific endocytic rate at 36 months of age than at 3 or 12 months of age (Table $111-4)$, the increased uptake of ${ }^{125}$-PVP with age is caused by am increase in the wet weight of the organs.

The finding of an age-related increase in fluid-phase endocytosis is consistent with the increased albumin elimination previously reported in this rat strain (Horbach et al., 11983 ; Chapter 11). Table 111-5 shows the amount of albumin eliminated sollely by fluid-phase endocytosis. It can be seen that the increase in total albumin ellimination is accompanied by an increase in albumin elimination via fluid-phase endocytic 
processes. In all the age-groups examined, fluid-phase endocytosis accounts for $34-46 \%$ of the total albumin elimination. On the other hand, albumin elimination has also been shown to be dependent upon the albumin molecule itself. When albumin isolated from 3-month-old rats was injected into 36-month-olds, no change in elimination rate was seen over that which is present at 24 months of age. However, the 36month-old rats eliminated albumin isolated from rats of the same age much more rapidly (Horbach et al., 1983; Chapter 11). Since fluidphase endocytosis is a nonspecific process, a change in the albumin molecule leading to an alteration in albumin elimination cannot be explained by this endocytic process. Nevertheless, the results of Baynes and Thorpe (1981) and of Yedgar et al. (1983) with respect to albumin catabolism in rats and rabbits, show an extremely good correlation between the sites of albumin uptake, and the sites of uptake of 125 J-PVP (Munniksma et al., 1980; Horbach et al., 1984b; Horbach et al., 1986b) (Table (II-3). Whether there is an additional age-related specific elimination process for albumin, remains to be determined.

It can be concluded that fluid-phase endocytosis is an important mechanism for albumin elimination and that age-related changes in albumin elimination in female WAG/Rij rats are mainly, but not solely. the result of age-related changes in fluid-phase endocytosis. 


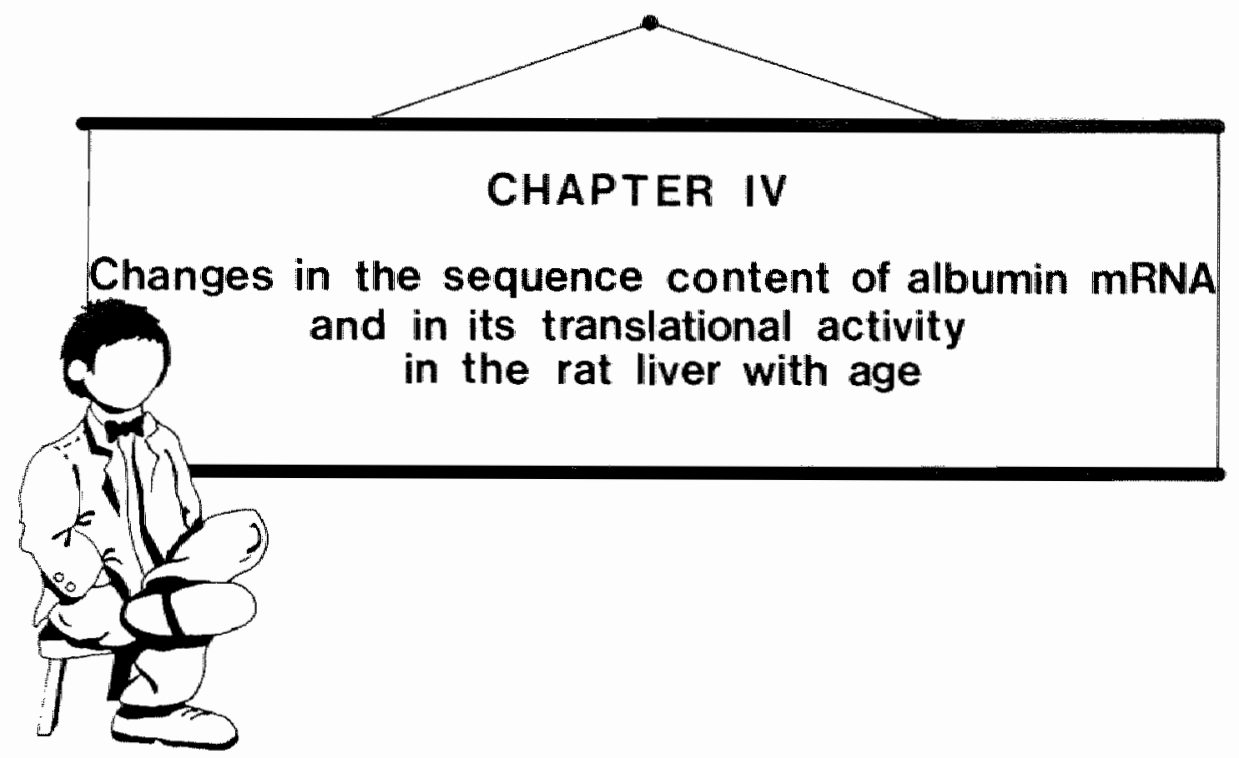

IV-1. INTRODUCTION

Aging in a number of species appears to be accompanied by a change in the capacity to synthesise proteins. Most of the investigations on the influence of age on protein synthesis have been performed using rat or mouse liver tissue. Although several studies indicate an age-related decline in protein synthesis, there is still considerable controversy concerning the mechanisms by which aging might influence the synthesis of proteins (Richardson, 1981; Richardson \& Birchenall-Sparks, 1983).

Since the liver has a high protein-synthesising activity, this organ has been chosen by many investigators for the study of changes in the capacity for protein synthesis as a function of age. Of the proteins synthesised solely by the liver, albumin is one of the few that has been extensively studied. Studies in vitro with liver microsomes isolated from male Fischer 344 rats showed an increase in albumin synthe- 
sis between the ages of 15 and 24 months (Chen et al., 1973). However, no change in total protein synthesis was found. Van Bezooijen and co-workers showed that the capacity of hepatocytes isolated from female WAG/Rij rats to synthesise albumin was less at 24 months than at 3 and 12 months of age, whereas it was higher at 30 and 36 months of age compared with what was observed in the animals aged 12 and 24 months (Van Bezooijen et al., 1976; Van Bezooijen \& Knook, 1977).

Studies in vivo on age-related changes in albumin synthesis have been performed by Beauchene et al. (1970), Salatka et al. (1971) and Ove et al. (1972). All these studies reported an increase in albumin synthesis with age between the age-groups investigated, namely 11and 28-month-old male and female Wistar rats (Beauchene et al., 1970), 1.5- and 20-month-old female Fischer rats (Salatka et al., 1971) and 1and 20-month-old female Fischer rats (Ove et al., 1972), respectively.

This chapter will focus on the effect of aging on the distribution of free and membrane-bound polyribosomes in the rat liver, the capacity of polyribosomes to synthesise albumin and total proteins in a cell-free system and on the albumin messenger RNA content of various RNA fractions as determined by molecular hybridization with albumin complementary DNA.

\section{IV-2. MATERIALS AND METHODS}

IV-2a. Animals and materials

The mean weights ( \pm S.D., 12 animals per group) of the 3-, 12-, 24- and 36-month-old female WAG/Rij rats were $146 \pm 11,194 \pm 12,211$ \pm 21 and $196 \pm 15 \mathrm{~g}$, respectively.

All glassware and solutions were autoclaved prior to use. EDTA, phenol, sodium deoxycholate, sallts, solvents and ribonuclease-free sucrose were purchased from E. Merck (Darmstadt, FRG); Dithiothreitol, heparin (from porcine intestinal mucosa), unlabeled amino acids and HEPES were obtained from Sigma (St. Louis, USA); Deoxyribonucleoside triphosphates, creatine phosphate and creatine kinase (rabbit 
muscle) from Boehringer (Mannheim, FRG). Glutathione was obtained from Aldrich (Brussels. Belgium); Triton $X-100$ and SDS from BDH chemicals Ltd. (Poole, UK). L- $\left(4-5-{ }^{3} \mathrm{H}\right.$ )-Leucine (spec. act. $61 \mathrm{Ci} / \mathrm{mmol}$ ) was purchased from the Radiochemical Centre (Amersham, Bucks, UK). Oligo(dT) ${ }_{12-18^{-c e l l u l o s e}}$ (type $T_{2}$ ) was obtained from Collaborative Research, Inc. (Waltham, MA, USA). Nuclease $S_{1}$ (Aspergillus oryzae) was purchased from Miles Laboratories, (Slough, UK), and stored at a concentration of $2.5 .10^{5}$ units $/ \mathrm{ml}$ in $50 \%$ glycerol/100 $\mathrm{mM} \mathrm{NaCl} / 20 \mathrm{mM}$ $\mathrm{KH}_{2} \mathrm{PO}_{4} / 5 \mathrm{mM} \mathrm{Na}{ }_{2} \mathrm{HPO}_{4}(\mathrm{pH} 7.0)$ at $-20^{\circ} \mathrm{C}$. Stripped rabbit liver tRNA was obtained from Gibco (Uxbridge, UK). Rabbit reticulocyte lysate was obtained from B.R.L. (Gaithersburg, USA).

\section{IV-2b. Assays}

1. Isolation of total post-nuclear RNA

Total post-nuclear RNA was prepared as described by Taylor $\varepsilon$ Schimke (1973). Rat livers were perfused in situ with a rinse solution $[0.25 \mathrm{M}$ sucrose $/ 1 \mathrm{mM} \mathrm{MgCl} 2$ ]. The livers were excised, washed and homogenized in 4 volumes of homogenizing buffer $150 \mathrm{mM}$ Tris. $\mathrm{HCl}(\mathrm{pH}$ $7.4) / 25 \mathrm{mM} \mathrm{NaCl} / 5 \mathrm{mM} \mathrm{MgCl}_{2} / 0.25 \mathrm{M}$ Sucrose/ $0.3 \mathrm{mg} / \mathrm{ml}$ heparin). After addition of $1 / 10$ volume of $10 \%$ Triton $X-100$, the homogenate was centrifuged for $20 \mathrm{~min}$. at $16,000 \times \mathrm{g}$. The supernatant was collected, $1 / 10$ volume of $10 \%$ sodium deoxycholate was added as well as $1 / 2$ volume of $0.3 \mathrm{M} \mathrm{NaCl} / 1.59 \mathrm{SDS} / 15 \mathrm{mM}$ EDTA/ $30 \mathrm{mM}$ Tris. HCl $/ \mathrm{pH}$ $9.0)$. An equal volume of water-saturated phenol/chloroform/isoamylalcohol $(50: 49: 1)$ was added and the RNA was extracted. After two successive extractions the RNA was precipitated with absolute ethanol overnight at $-20^{\circ} \mathrm{C}$ and isolated by centrifugation at $16,000 \times \mathrm{g}$ for 20 $\min$. at $4^{\circ} \mathrm{C}$. 
Polyadenylated RNA was prepared from total post-nuclear RNA by double oligo(dT)-cellulose chromatography as described by Strair et al. (1977). In short, a column of oligo(dT)-cellulose with a total bed volume of $0.5 \mathrm{ml} / \mathrm{mg}$ RNA was prepared and pre-washed with $10 \mathrm{mM}$ Tris. HCl ( $\mathrm{pH} 7.4) / 0.5 \mathrm{M} \mathrm{NaCl} / 0.5 \%$ SDS/1 $\mathrm{mM}$ EDTA (Buffer \|). Total post-nuclear RNA (dissolved in Buffer I) was applied to the column and the column was washed with Buffer I until the optical density (260 $\mathrm{nm})$ of the eluate was lower than 0.02 . Next the column was washed with $10 \mathrm{mM}$ Tris. $\mathrm{HCl}(\mathrm{pH} 7.4) 10.1 \mathrm{M} \mathrm{NaCl} / 0.58$ SDS until the optical density $(260 \mathrm{~nm})$ of the eluate was lower than 0.02 . The bound RNA was eluted with $10 \mathrm{mM}$ Tris.HCI $(\mathrm{pH}$ 7.4] $10.5 \%$ SDS. This eluate was adjusted to $0.5 \mathrm{M} \mathrm{NaCl}$, re-applied to the column and all the above steps were repeated.

3. Isolation of free and membrane-bound polyribosomes

Free and membrane-bound polyribosomes were isolated by the method of Ramsey, and Steele (1976). The livers of rats were perfused in situ with a rinse solution $\left(250 \mathrm{mM}\right.$ sucrose/1 $\left.\mathrm{mM} \mathrm{M \textrm {gCl } _ { 2 }}\right)$. The livers were excised, washed and homogenized in 4 volumes of homogenizing buffer $[50 \mathrm{mM}$ HEPES $(\mathrm{pH} 7.4\} / 75 \mathrm{mM} \mathrm{KCl} / 5 \mathrm{mM} \mathrm{MgCl} / 3 \mathrm{mM}$ glutathione $/ 250 \mathrm{mM}$ sucrose). Centrifugation at $131,000 \times \mathrm{g}$ for $12 \mathrm{~min}$. was performed to separate the large particulate fraction from the free polyribosomes and cell sap. The particulate fraction was resuspended in cell sap containing $250 \mathrm{mM} \mathrm{KCl}$ using a tight-fitting Dounce homogenizer after addition of $1 / 9$ volume of $10 \%(w / v)$ Triton $x-100$. The membrane-bound polyribosomes were separated from the nuclei by centrifuglation at $1,470 \times \mathrm{g}$ for $5 \mathrm{~min}$. A $1 / 9$ volume of $13 \%(\mathrm{w} / \mathrm{v})$ sodium deoxycholate was then added to solubilize membranes. Both membranebound and free polyribosomes were purified by centrifugation through a discontinuous sucrose gradient. $4 \mathrm{ml}$ of the membrane-bound or free polyribosome suspension were layered onto a $3 \mathrm{ml}$ cushion of $2 \mathrm{M} \mathrm{su-}$ 
crose in cell sap and a $3 \mathrm{ml}$ cushion of $1.38 \mathrm{M}$ sucrase in cell sap. Centrifugation was performed at $174,000 \times \mathrm{g}$ for 20 hours. The pellet was resuspended in $10 \mathrm{mM}$ HEPES $(\mathrm{pH} 7.4) / 75 \mathrm{mM} \mathrm{KCl} / 5 \mathrm{mM} \mathrm{MgCl} / 3$ $\mathrm{mM}$ glutathione and kept at $-70^{\circ} \mathrm{C}$.

4. Preparation of cell sap

One volume of homogenizing buffer was added to livers of rats of different ages. After homogenization, the material was centrifuged for 10 minutes at $17,000 \times 9$ at $4^{\circ} \mathrm{C}$. Pelleted material was discarded and the supernatant fraction was re-centrifuged for 95 minutes at 365,000 $x \mathrm{~g}$. The cell sap was harvested from the upper three quarters of the supernatant fraction, excluding the lipid layer, and the concentration was adjusted to $250 \mathrm{mM} \mathrm{KCl}$ for the isolation of polyribosomes. For the cell-free protein synthesis, orginal cell sap with $75 \mathrm{mM} \mathrm{KCl}$ was used.

5. Polyribosome profile analysis

Approximately $6 \mathrm{~A}_{260}$ units of free or membrane-bound polyribosomes were diluted to $300 \mu \mathrm{l}$ with a buffer comprising $10 \mathrm{mM} H E P E S$ $(\mathrm{pH} 7.4) / 75 \mathrm{mM} \mathrm{KCl} / 5 \mathrm{mM} \mathrm{MgCl} / 3 \mathrm{mM}$ glutathione and were layered over a $12 \mathrm{ml} 10-40$ 号 $(\mathrm{W} / \mathrm{W})$ isokinetic sucrose gradient containing 0.5 $\mathrm{mM}$ EDTA. Centrifugation was carried out for $60 \mathrm{~min}$. at $280,000 \times \mathrm{g}$. The gradients were withdrawn from the top of each tube and absorbance at $254 \mathrm{~nm}$ was monitored with a Gilford $2400-2$ recording system.

6. Quantitative determination of the RNA content

The RNA content in the fractions prepared from liver homogenates was determined by the method of Fleck \& Munro (1962). Normal perchloric acid (PCA) was added to the homogenate to a final concentration of $0.7 \mathrm{~N}$. After a $15 \mathrm{~min}$. incubation in an ice-bath, the homogemate was centrifuged for $5 \mathrm{~min}$. in an Eppendorf-centrifuge. The 
pellet was washed twice with $0.7 \mathrm{~N}$ PCA, dried and resuspended in 0.3 N KOH. After a 1 hour incubation at $37^{\circ} \mathrm{C}$, the suspension was neutralized by the addition of $1 / 7$ volume of $2.1 \mathrm{~N}$ PCA. One volume of $0.5 \mathrm{~N}$ PCA was added and the suspension was centrifuged for 2 min. in an Eppendorf-centrifuge. The pellet was washed twice with $0.5 \mathrm{~N}$ PCA. The supernatants were comblined and the absorbance at $260 \mathrm{~nm}$ was measured. A standard curve was obtained with known amounts of E. Coll tRNA. An absorbance of 1 at $260 \mathrm{~mm}$ corresponded to a RNA concentration of about $32 \mu \mathrm{g} / \mathrm{ml}$.

7. Cell-free protein synthesis

Cell-free protein synthesis was performed in a 25 ull incubation mixture as described by Grossman et all (1977). Polyribosomes were incubated for $15 \mathrm{~min}$. at $30^{\circ} \mathrm{C}$. Reaction mixtures contained $15 \mathrm{mM}$ Tris. HCl $(\mathrm{pH} 7.5) / 1 \mathrm{mM}$ dithiothreiltol/1 $\mathrm{mM}$ ATP/0.2 $\mathrm{mM}$ GTP/10 $\mathrm{mM}$ creatine phosphate/ $2.5 \mu \mathrm{g}$ creatine kinase (rabbit muscle)/19 unlabeled amino acids minus leucine according to Palmiter $[1973] / 0.03 \mathrm{~A}_{260}$ units of stripped rabbit liver tRNA/ $1 \mu \mathrm{Ci} L-\left(4.5-{ }^{3} \mathrm{H}\right)$-leucine $(61 \mathrm{Ci} / \mathrm{mmol})$. Optimal conditions for $\left({ }^{3} \mathrm{H}\right)$-leucine incorporation were determined by varying the concentration of potassium acetate, magnesium acetate and cell sap. Maximal incorporation was found at $75 \mathrm{mM}$ potassium acetate, $4 \mathrm{mM}$ magnesium acetate and $2 \mu \mathrm{l}$ cell sap using $0.05-0.4 \mathrm{~A}_{260}$ units of free or membrane-bound polyribosomes. Incorporation of $\left({ }^{3} \mathrm{H}\right)$-leucine into protein was measured as labeled polypeptide which was insoluble in 108 trichloroacetic acid.

8. In vitro translation in a reticulocyte Iysate

The in vitro translations were performed as described by Strohman et al. (1977). Poly $(A)^{+}-$RNA $[0.05-0.5 \mu \mathrm{g})$ was incubated for $60 \mathrm{~min}$. at $30^{\circ} \mathrm{C}$. Reaction mixtures (with a final volume of $30 \mu l$ ) contained 25 $\mathrm{mM}$ HEPES $(\mathrm{pH} 7.2) / 10 \mathrm{mM}$ creatine phosphate/25 $\mu \mathrm{g}$ creatine kina- 
se/19 unlabeled amino acids minus leucine $(50 \mu \mathrm{M}$ each $/ 4+5 \mu \mathrm{Ci}$ L$\left(4,5-{ }^{3} \mathrm{H}\right)$-leucine $(61 \mathrm{Ci} / \mathrm{mmol})$. Optimal conditions for $\left({ }^{3} \mathrm{H}\right)$-leucine incorporation were determined by varying the concentration of potassium acetate and magnesium acetate. Maximal incorporation was found at 135 $\mathrm{mM}$ potassium acetate and $1.2 \mathrm{mM}$ magnesium acetate. Incorporation of $\left({ }^{3} \mathrm{H}\right)$-leucine into protein was measured as labeled polypeptide which was insoluble in 108 trichloroacetic acid.

9. Immunological analysis of albumin synthesis in cell-free reactions

Determination of $\left({ }^{3} \mathrm{H}\right)$-albumin in the cell-free protein synthesis reaction product was performed by immunoprecipitation. For these studies approximately $2.4 \mathrm{~A}_{260}$ units of free or membrane-bound polyribosomes were used or approximately $2 \mu \mathrm{g}$ of $\operatorname{poly}(\mathrm{A})^{+}-\mathrm{RNA}$ with a proportionate increase in other reaction components. After protein synthesis was completed, un-labeled leucine was added to a concentration of 10 $\mathrm{mM}$ and the reaction mixture was placed on ice. The incorporation of radioactivity into hot trichloroacetic acid-insoluble polypeptides was determined in a $10 \mu \mathrm{l}$ aliquot. The residual mixtures were then diluted to $1 \mathrm{ml}$ with buffer comprising $10 \mathrm{mM}$ sodium phosphate $(\mathrm{pH} \mathrm{7.2)/150}$ $\mathrm{mM} \mathrm{NaCl} / 1 \%$ Triton $X-100 / 0.5 \%$ sodium deoxycholate/0.19 SDS and centrifuged for $15 \mathrm{~min}$. at $225,000 \times \mathrm{g}$. To the supernatant $1,000-2,000 \mathrm{cpm}$ of rat $\left.{ }^{(14} \mathrm{C}\right)$-labeled albumin was added as tracer for recoveries and subsequently $15 \mathrm{\mu g}$ of unlabeled rat albumin as carrier for precipitation and goat-anti-rat-albumin $\gamma$-globulin were added. After 16 hours of incubation at $4^{\circ} \mathrm{C}$, the mixture was layered over a $200 \mu \mathrm{l} 10 \%$ ( w/V) sucrose cushion in the same buffer and centrifuged in an Eppendorf centrifuge at $10,000 \times \mathrm{g}$ for $8 \mathrm{~min}$. The pellet was resuspended in buffer, washed and re-centrifuged. This wash procedure was repeated three times. The pellet was dissolved in $0.1 \mathrm{~N} \mathrm{NaOH}$ and then re-precipitated with $10 \%$ trichloroacetic acid for counting. (using a doublelabeling program). 
10. Preparation of $\left({ }^{14} \mathrm{C}\right)$-albumin

$\left({ }^{14} \mathrm{C}\right)$-Albumin was prepared chemically from purified albumin with $\left({ }^{14} \mathrm{C}\right)$-formaldehyde by reductive methylation as described by Crane and Miller (1975).

A solution of rat serum albumin $116 \mathrm{mg}$ in $4 \mathrm{mll}$ of $0.01 \mathrm{M}$ borate buffer $(\mathrm{pH} \mathrm{9.0)}$, containing $0.3 \mathrm{M} \mathrm{KCl)}$ was allowed to react with 4.4 umoles of $\left({ }^{14} \mathrm{C}\right)$-formaldehyde $(59 \mathrm{mCi} / \mathrm{mmole})$ for $3 \mathrm{~min}$. at $0^{\circ} \mathrm{C}$. The formaldiehyde-albumin adduct was reduced by adding 7 umoles of som dium borohydride. The residual $\left({ }^{14} \mathrm{C}\right)$-methanol was removed by repeated dialysis against $0.3 \mathrm{M} \mathrm{KCl} / 0.1 \mathrm{mM}$ EDTA.

\section{Anallytical RNA-CDNA hybridization}

Analytical RNA-CDNA hybridization was performed according to the method of Housman et al. (1974) in $5 \mu$ sealled capillary tubes containing $0.2 \mathrm{M}$ sodium phosphate buffer (pH 6.8)/0.58 SDS/1000 cpm $\left({ }^{3} \mathrm{H}\right)-\mathrm{cDNA}$ (spec. act. $7.5-10^{6} \mathrm{cpm} / \mu \mathrm{g}$ ) and the required amount of RNA. The reaction mixture was heated at $100^{\circ} \mathrm{C}$ for $2 \mathrm{~min}$. and then incubated at $65^{\circ} \mathrm{C}$ for 2 to 16 hours. After incubation, samples were diluted 400-fold in $30 \mathrm{mM}$ sodium acetate $[\mathrm{pH} 4.5] / 300 \mathrm{mM} \mathrm{NaCl} / 1 \mathrm{mM}$ $\mathrm{ZnSO}_{4} / 10 \mu \mathrm{g} / \mathrm{ml}$ denaturated and $5 \mathrm{\mu g} / \mathrm{ml}$ double-stranded calf thymus DNA. Hybrid formation was monitored by determining the percent input of $\left({ }^{3} \mathrm{H}\right)$-dCTP-labeled cDNA, which was insoluble in $10 \%$ trichloroacetic acid after digestion with $250 \mathrm{U} / \mathrm{ml}$ nuclease $S_{1}$ at $45^{\circ} \mathrm{C}$ for $30 \mathrm{~min}$. Trichloraacetic acid-precipitable material was collected on a nitrocellulose filter and counted by liquid scintillation spectroscopy.

\section{IV-3. RESULTS}

IV-3a. Yield and size of isolated polyribosomes

In order to study the effect of age on the albumin and total protein synthesis in vitro and on the distribution of free and membrane- 
Table IV-1 INFLUENCE OF AGE ON THE RNA CONTENT OF SEVERAL FRACTIONS PREPARED FROM LIVER HOMOGENATES OF FEMALE WAG/Rij RATS

RNA content (mg/g liver)

$\begin{array}{llllll}\text { Age (months) } & N & 3 & 12 & 24 & 36\end{array}$

Total post-

nuclear RNA

$66.31 \pm 0.12$

$6.50 \pm 0.52$

$6.29 \pm 0.45$

$6.48 \pm 0.60$

Poly $(A)^{+}-$RNA

$30.11 \pm 0.02$

$0.15 \pm 0.03$

$0.12 \pm 0.02$

$0.13 \pm 0.04$

"Poly $(A)^{-1}-$ RNA

$36.26 \pm 0.15$

$6.01 \pm 0.30$

$6.28 \pm 0.22$

$5.92 \pm 0.51$

membrane-bound

polyribosomes

$33.62 \pm 0.29$

$3.54 \pm 0.11$

$3.44 \pm 0.13$

$3.69 \pm 0.46$

free polyri-

bosomes

$31.22 \pm 0.09 \quad 1.15 \pm 0.04 \quad 1.31 \pm 0.12 \quad 1.21 \pm 0.17$

Values are expressed as means $\pm S . D$. for $N$ experiments with two livers per experiment.

bound polyribosomes, quantitative isolations of un-degraded polyribosomes were performed as described by Ramsey and Steele (1976). As shown in Table IV-1, there was no age-related change in the distribution of free and membrane-bound polyribosomes. The membrane-bound polyribosomes comprised approximately $75 \%$ of the total liver polyribosomes. The yield of polyribosomes was approximately $75 \%$ of total RNA due to a lass of monosomes and ribosomal subunits during the isolation procedures. These results are similar to previous findings from the literature (Ramsey \& Steele, 1976; Princen et al., 1981).

The size of the isolated polyribosomes was determined by isokinetic sucrose gradient centrifugation. Fig. IV-1 depicts a representative result. No age-related changes in the polyribosomal size were observed 
in membrane-bound or free polyribosomal fractions. The average size of the free polyribosomes was larger than that of the membrane-bound ones in all the age-groups investigated. The peak which sediments at the monosome fraction of the free polyribosomes is attributed to ferritin.
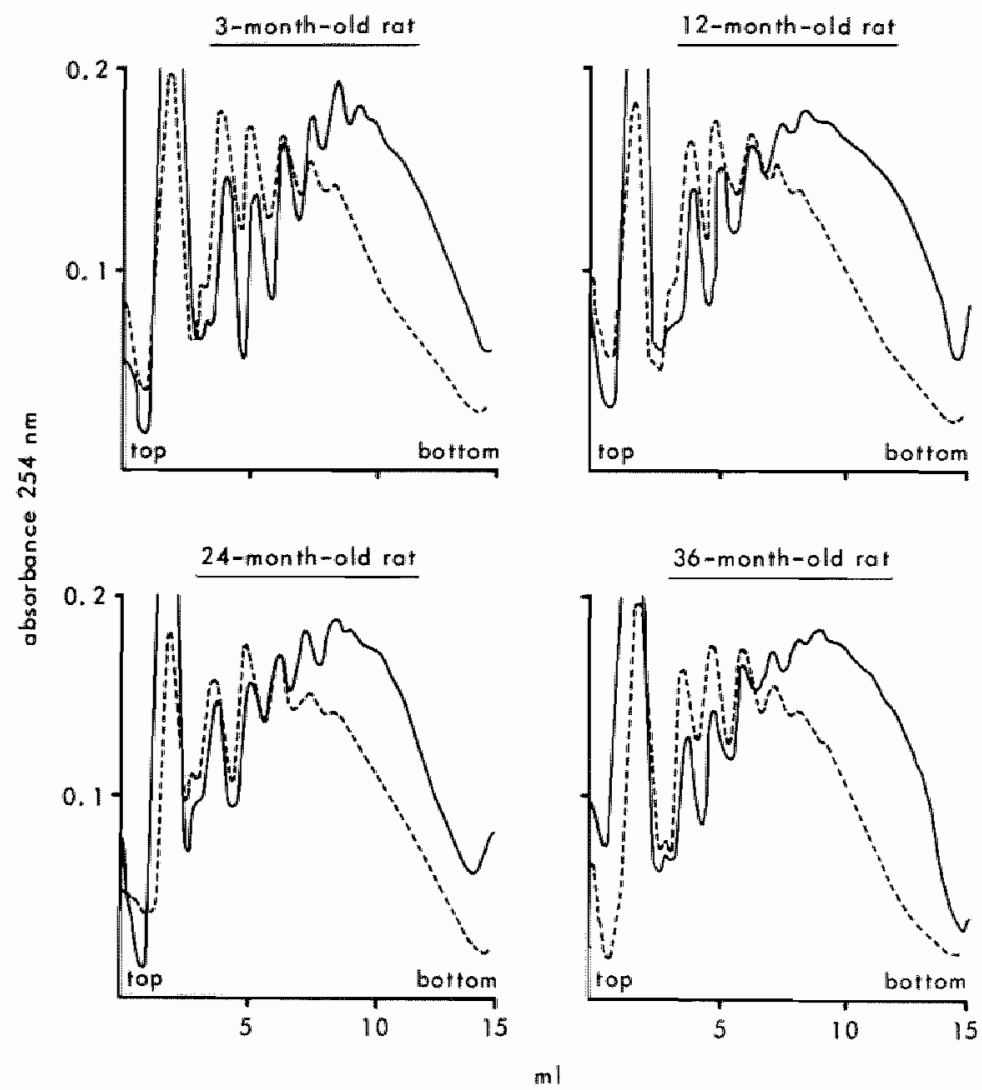

Fig. IV-i. Sucrose gradient analysis of free and membrane-bound liver polyribosames from female WAG/Rij rats of wariaus ages

About $5 \mathrm{~A}_{260}$ units of polyribosomes were analyzed by sucrose gradient. centrifugation (see Materials and Methods).

-...- nembrane-bound polyribosomes free polyribosomes 
IV-3b. Cell-free incorporation of labeled amino acid into total protein and albumin

The assays for protein synthesis were standardised for maximal incorporation using polyribosomes and cell sap prepared from rats of the four age-groups. Incorporation of $\left({ }^{3} \mathrm{H}\right)$-leucine into protein was linear for at least $15 \mathrm{~min}$ at $30^{\circ} \mathrm{C}$ for all polyribosome preparations. The protein synthesis was performed with variable amounts of polyribosomes up to $20 \mathrm{\mu g}$ RNA. From these studies, the $\left({ }^{3} \mathrm{H}\right)$-leucine incorporation per $\mu \mathrm{g}$ RNA was calculated. The results are given in Table IV-2A. No change with age was found in the protein synthesis of either free or membrane-bound polyribosomes. Furthermore, no change in the translational activity of the polyribosomes was observed using either agematched cell sap or cell sap prepared from livers of 3-month-old rats .

The synthesis of albumin-like material in the cell-free translations was determined by immunoprecipitation using $\left({ }^{14} \mathrm{C}\right)$-labeled albumin as tracer for recoveries. As demonstrated in Table $I V-2 B$, the albumin synthesis by free polyribosomes remained unchanged with age whereas the albumin synthetic activity per $\mu \mathrm{g}$ RNA of membrane-bound polyribosomes was higher at 24 and 36 months of age when compared with younger animals.

IV-3c. RNA content in various subcellular fractions

To determine whether age-related changes in the synthesis of albumin in rats are regulated at the RNA level, post-nuclear RNA and RNA from membrane-bound and free polyribosomal fractions were prepared from livers of rats of different ages. Polyadenylated RNA was isolated from total post-nuclear RNA. The results are presented in Table IV-1. No age-related changes in the RNA content per gram of rat liver were observed. However, the RNA content of the several RNA fractions expressed per whole liver was significantly higher in rats of 36 months of age than in the other age groups due to a significant increase in liver weight (Table IV-3). 
Table IV-2 EFFECT OF SUPERNATANT FACTORS ON TOTAL PROTEIN SYNTHESIS AND SYNTHESIS OF ALBUMIN-LIKE MATERIAL BY FREE AND MEMBRANE-BOUND LIVER POLYRIBOSOMES OF FEMALE WAG/Rij RATS OF DIFFERENT AGES

$$
\begin{array}{lrr}
\text { Age (months) } \\
3 \\
12 & 24 & 36
\end{array}
$$

(A) cpm $\left({ }^{3} \mathrm{H}\right)$-leucine incorporated into protein/ $\mu \mathrm{g}$ RNA

Membrane-bound

polyribosomes in

-age-matched

$\begin{array}{llll}\text { cell sap } & 2300 \pm 160 & 2150 \pm 1202450 \pm 170 & 2050 \pm 200 \\ \text {-cell sap from } & & & \\ 3-\text { month-old rats } & 2400 \pm 210 & 2300 \pm 1302200 \pm 150 & 2075 \pm 170\end{array}$

Free polyribosomes in

-age-matched

$\begin{array}{lrll}\text { cell sap } & 4250 \pm 300 & 4100 \pm 2804550 \pm 320 & 4350 \pm 270 \\ \text {-cell sap from } & & & \\ 3 \text {-month-old rats } & 4130 \pm 280 & 4230 \pm 2904380 \pm 220 & 4480 \pm 180\end{array}$

(B) Albumin synthesis as percentage of total protein synthesis

Membrane-bound

polyribosomes in

-age-matched

cell sap

-cell sap from

$9.8 \pm 0.311 .0 \pm 0.814 .6 \pm 0.5^{a, b} 14.9 \pm 0.7^{a, b}$

3-month-old rats

$10.1 \pm 0.410 .7 \pm 0.615 .0 \pm 0.6^{a, b} 14.8 \pm 0.7^{a, b}$

Free polyribosomes in

-age-matched
cell sap
$1.4 \pm 0.1 \quad 1.4 \pm 0.2 \quad 1.5 \pm 0.3$
$2.0 \pm 0.5$
-cell sap from
3-month-old rats
$1.5 \pm 0.4$
$1.3 \pm 0.1 \quad 1.6 \pm 0.3$
$1.8 \pm 0.5$

Cell-free protein synthesis with liver polyribosomes was investigated in age-matched cell sap and cell sap isolated from livers of 3-month-old rats. Values are expressed as means $\pm S$.D. for a minimum of 3 experiments with two livers per experiment.

a: value differs significantly $(p<0.05)$ from 3 -month value

$b$ : value differs significantly $(p<0.05)$ from 12 -month value 
Table IV-3 AGE-RELATED CHANGES IN THE LIVER WEIGHT OF FEMALE WAC/Rij RATS

Age N

(months)
Liver weight

(g)

$$
\begin{aligned}
& 4.71 \pm 0.38 \\
& 4.65 \pm 0.57 \\
& 4.94 \pm 0.55 \\
& 6.79 \pm 0.89^{a, b, c}
\end{aligned}
$$

Values are expressed as means $\pm S . D$.

$N$ : the number of animalls

a: value differs significantly $\llbracket p<0.05 \rrbracket$ from 3 -month value

$b$ : value differs significantly $(p<0,05)$ from 12 -month value

$c$ : value differs significantly $\{p<0.05\}$ from 24 -month value

$\| V-3 d$. Albumin mRNA sequence content

The content of albumin mRNA in various RNA fractions was determined by a molecular hybridization technique using a labeled albumin cDNA probe. Fig. IV-2 shows the specificity of the cDNA probe for albumin mRNA. Under the stringent reaction conditions used, there was no annealing between the cDNA and purified fibrinogen polypeptide mRNA's. From comparison of the individual hybridization curves with that of $100 \%$ pure albumin mRNA, the relative proportion of albumin mRNA in each fraction could be calculated. The results of this albumin mRNA quantitation are given in Table IV-4 and IV-5.

The amount of albumin mRNA sequences per mo of RNA is greater at 24 and 36 months of age than at 3 and 12 months of age in the post-nuclear RNA fraction. This higher content of albumin mRNA is attributed to the increased albumin mRNA content in the membrane- 
bound polyribosomal fraction and especially in the poly $(A)^{-}-$RNA fraction (Table IV-4).

Table IV-5 shows the age-related changes in the albumin mRNA content per wholle liver.

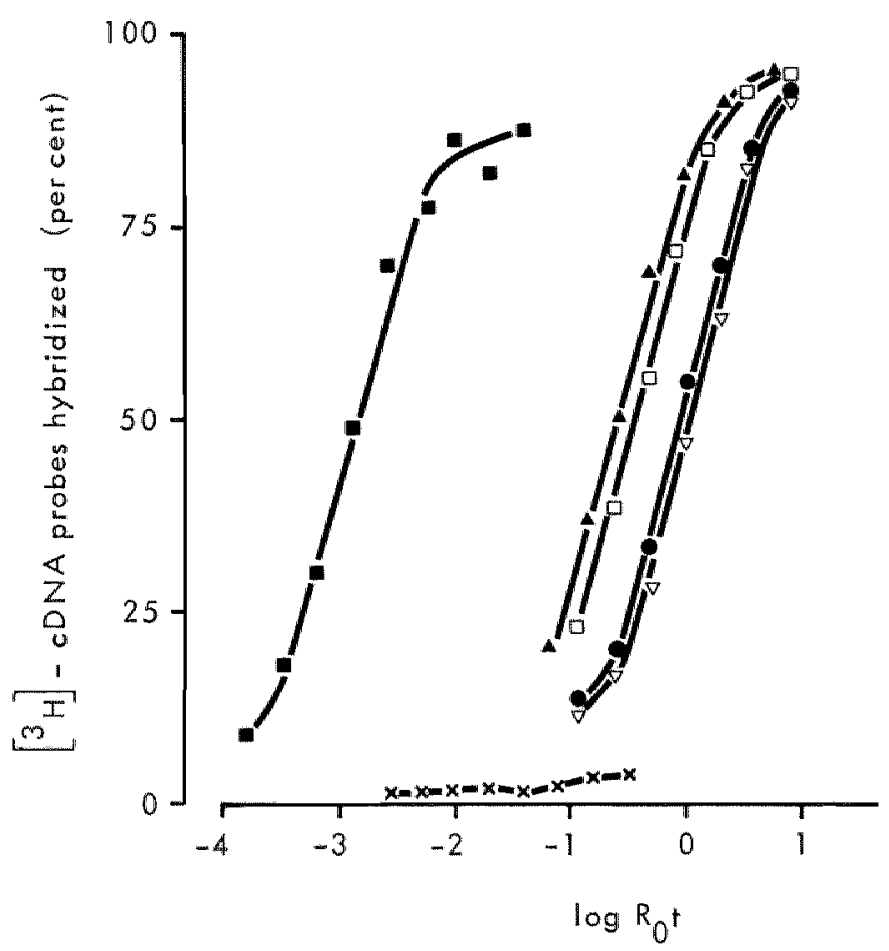

Fig. IV-2, Hybridization kinetics of different RNA fractions from rat liver using (3) - DNA complementary to albumin mRNA.

( $\left.{ }^{3} \mathrm{H}\right)$-DNA complementary to albumin mRNA was hybridized to purified albumin mRAA (a), to purified fibrinogen polypeptide mRNA"s $(x)$ and to total postnuclaar RNA from $3-(\nabla), 12-(C), 24-($ a) $)$ and 36 -month-old (4) rats. 
Table IV-4 AGE-RELATED CHANGES IN THE RELATIVE AMOUNT OF ALBUMIN MRNA IN SEVERAL RNA-FRACTIONS PREPARED FROM LIVER HOMOGENATES OF FEMALE WAG/RII RATS

Relative albumin mRNA content as percentage of total RNA
Age (months)
3
12
24
36

Total post-

nuclear RNA $\quad 0.15 \pm 0.01 \quad 0.17 \pm 0.02 \quad 0.31 \pm 0.02^{a, b} 0.31 \pm 0.02^{a, b}$

Poly $(A)^{+}-$RNA $3.4 \pm 0.4^{\circ} \quad 4.0 \pm 1.3 \quad 4.2 \pm 0.4 \quad 4.1 \pm 0.5$

"Poly $(A)^{-11-R N A 0.06 \pm 0.01} \quad 0.07 \pm 0.02 \quad 0.20 \pm 0.02^{a, b} 0.23 \pm 0.04^{a, b}$

membrane-bound

polyribosomes $0.22 \pm 0.08 \quad 0.23 \pm 0.07 \quad 0.44 \pm 0.10^{\mathrm{a}, \mathrm{b}} 0.46 \pm 0.12^{\mathrm{a}, \mathrm{b}}$

free palyri-

bosomes

$0.002 \pm 0.000 \quad 0.002 \pm 0.000 \quad 0.002 \pm 0.000 \quad 0.002 \pm 0.000$

Values are expressed as means \pm S.D. for a minimum of 3 experiments with two livers per experiment.

a: value differs significantly $(P<0.05)$ from 3 -month value

$b$ : value differs significantly $(P<0.05)$ from 12 -month value

Apart from the increase in albumin mRNA concentration at between 12 and 24 months of age, an increase in total liver albumin mRNA content at between 24 and 36 manths of age is observed, which is due to an increase in liver weight. It is notable that at 24 and 36 months of age, more albumin mRNA is present in the poly $(A)^{-}-$RNA than in poIy $(A)^{+}-R N A$, indicating the absence or shortening of the poly $(A)$-tail of albumin mRNA's with age. 
Table IV-5 INFLUENCE OF AGE ON THE ALBUMIN MRNA CONTENT IN SEVERAL RNA-FRACTIONS PREPARED FROM LIVER HOMOGENATES OF FEMALE WAG/RIj RATS

$\begin{array}{ccccc} & & \text { Albumin mRNA content per wholle liver (ug) } \\ \text { Age (months) } & 3 & 12 & 24 & 36\end{array}$

Total postnuclear RNA

$$
44.5 \pm 4.247 .8 \pm 2.196 \pm 10^{a, b} 137 \pm 11^{a, b}, c
$$

Poly $(A)^{+}-$RNA $\quad 16.8 \pm 3.928 \pm 11 \quad 24.8 \pm .5 .5 \quad 38 \pm 13^{\mathrm{a}}$ "Poly[A]"-RNA 16.1 $\pm 1.920 .0 \pm 4.061 .3 \pm 4.3^{a, b} 96 \pm 12^{a, b . c}$ membrane-bound polyribosomes $42 \pm 15 \quad 38.4 \pm 9.0$ $70 \pm 14^{a} \cdot b \quad 109 \pm 20^{a}, b, c$ free polyribosomes $0.11 \pm 0.010 .11 \pm 0.010 .13 \pm 0.03$ $0.15 \pm 0.03$

Values are expressed as means \pm S.D. for a minimum of 3 experiments with two livers per experiment.

a: value differs significantly $(p<0.05)$ firom 3 -month value

$b$ : value differs significantly $(p<0.05)$ from 12 -month value

$c$ : value differs significantly $[p<0.05]$ from 24 -month value

IV-3e. In vitro translation of rat liver poly $(A)^{+}-$RNA

Polly $(A)^{+}$-RNA was translated in a rabbit reticulocyte lysate and the amount of albumin-like material was determined by immunoprecipitation. No change with age was observed in the translational efficiency of the albumin mRNA present in the poly $(A)^{+}-$RNA fraction (Table $\left.I V-6\right)$.

\section{IV-4. DISCUSSION}

In order to understand the physiological control of protein synthesis in the aging liver, it is essential to investigate the influence of aging on the protein synthesising machinery in this organ. The biosyn- 
Table IV-6 INFLUENCE OF AGE ON THE TRANSLATIONAL ACTIVITY OF POLY(A) ${ }^{*}$-RNA FROM RAT LIVER IN A RETICULOCYTE LYSATE AND THE SYNTHESIS OF ALBUMIN-LIKE MATERIAL

$\begin{array}{ccl}\text { Age } & \left({ }^{3} \mathrm{H}\right) \text {-leucine } & \text { albumin synthesis } \\ \text { (months) } & \text { incorporated into } & \text { as percentage of total } \\ & \text { protein }\left(10^{3} \mathrm{cpm} / \mu \mathrm{RNA}\right) & \text { protein synthesis }\end{array}$

$\begin{array}{rlll}3 & 30.2 & \pm 3.1 & 3.71 \pm 0.29 \\ 12 & 28.7 & \pm 3.1 & 3.53 \pm 0.71 \\ 24 & 31.8 & \pm 3.3 & 4.12 \pm 0.53 \\ 36 & 33.0 & \pm 3.0 & 3.98 \pm 0.40\end{array}$

In vitro translation of liver poly $(A)^{+}-$RNA of rats of various ages was performed in a reticulocyte lysate. Determination of the albumin-like material synthesised was done by immunoprecipitation as described in the "Materials and Methods"-section.

Values are expressed as means \pm S.D. for a minimum of three experiments with two livers per experiment.

thesis of a specific protein such as albumin may be operationally diwided into two simplified processes: a) transcription or synthesis of RNA's including messenger RNA and b) translation or the assembly of amino acids into protein under the direction of the specific mRNA. Any factor related to aging that affects RNA synthesis or the assembly of amino acids into a polypeptide chain might therefore have an effect on the synthesis of a specific protein.

The results of this study indicate that aging does not affect the distribution, content or average size of free and membrane-bound polyribosomes (Table IV-1, Fig. IV-1) in the liver of female WAG/Rij 
rats. The capacity of these polyribosomes to synthesise total protein is also unchanged (Table $\mid V-2)$. In these experiments, age-matched cell sap or cell sap prepared from livers of 3-month-old rats was utilized to study the possible role of age-related changes in the components of the translational system such as initiation, peptide chain elongation and termination factors in protein synthesis as suggested by Moldave et al. (1979). Although it has been reported that the protein synthetic activity of rat liver polyribosomes changes with age (Claes-Reckinger et al., 1982 J, our results cannot be compared with these findings. These authors assessed in vitro protein synthesis by using methods for the separation of microsomes from postmitochondrial supermatant. This approach has been subjected to the criticism that the postmitochondrial supernatant contains only a small, possibly unrepresentative portion of the membrane-bound polyribosomes (Blobel \& Potter. 1967; Venkatesan Er Steele, 1972).

Despite the unchanged activities of total protein synthesis in all age groups of animals as demonstrated in the present study, the synthesis of albumin-like material by membrane-bound polyribosomes as determined by immunoprecipitation is increased in rats of 24 and 36 months of age as compared with what is observed in younger ones ITable IV2B). This assay for the detection and quantitation of cell-free translation products of albumin mRNA may depend on factors other than the levell of albumin mRNA, such as monovalent and divalent ion concentration (Matthews et al., 1972; Roberts \& Patterson, 1973). certain initiation factors (Roberts \& Patterson, 1973; Heywood et al., 1974), etc. The utilization of radioactively labeled DNA complementary to messenger RNA has avoided these difficulties and has greatly facilitated studies on regulatory mechanisms in gene expression. In the present study, we have used albumin $\left({ }^{3} \mathrm{H}\right)$-CDNA to quantitate albumin mRNA sequence content in subcellular fractions of livers of rats of different age-groups. However, this assay does not require biological activity of the specific mRNA in terms of translatability, and this may limit certain interpretations. 
Although the finding of an increased albumin synthesis in the cellfree system at 24 and 36 months of age (Table $\mid V-2 b$ ) is consistent with the finding of increased albumin mRNA levels as determined by the molecular hybridization technique (Table $(\mathrm{V}-4)$ ), albumin synthesis in the cell-free system using age-matched cell sap or cell sap prepared from livers of 3-month-old rats is not proportionally increased with the albumin mRNA level $(50 \%$ versus $100 \%)$. This finding suggests that some, if not all, albumin mRNA's present in the liver of senescent rats could be biologically less active than those found in younger animals. Our results on the age-related increase in albumin mRNA are consistent with the hypothesis of Chen et al. (1973). They suggested that the increase in albumin sythesis in rat liver microsomes with age had to be attributed to an increase in the mRNA level. However, they did not directly measure the amount of this mRNA. Recently, Richardson et al. (1985) showed that the content of albumin mRNA in the liver of Fischer 344 rats was slightly decreased between 6 and 24 months of age. After 24 months of age, an increase in albumin mRNA levels was observed. These findings stress the role of the albumin mRNA in the age-related increase in albumin synthesis.

Because the results of many previous studies on mRNA in eukaryotic cells have been based on the use of poly $(A)^{+}-$RNA isolated from young rats, we thought that it was important to determine exactly what percentage of total polyribosomal albumin mRNA was present in the poly $(A)^{+}-$RNA of senescent rat livers. As shown in Table IV-5, the albumin mRNA's in livers of rats of 24 and 36 months are contained mostly in the poly $(A)^{-}-$RNA fraction as compared with the younger age-groups, although the overall yields of poly $(A)^{+}-$RNA were unchanged in animals of all age groups. These findings indicate an age-related shortening or absence of the poly $(A)$-tail specifically for albumin mRNA's. Shortening of poly(A)-tails of messenger RNA's with age due to a high turnover rate of this poly (A)-tail or as a result of transcription has previously been described in the quail oviduct, heart and liver (Bernd et al., 1982). In vitro translation of the poly(A) ${ }^{+}-$RNA of the rats of the four different age-groups in a reticulocyte lysate re- 
vealed that the translational capacity of the albumin $M R N A$ in this RNA-fraction did not change with age (Table $(V-6)$. In all the agegroups, $4 \mathrm{~g}$ of the synthesised protein appeared to be albumin-like material, which is consistent with the amount of albumin mRNA present in the poly $(A)^{+}$-RNA fraction (Table $(V-4)$. This suggests that the diminished translational activities of albumin $m R A^{\prime}$ 's of senescent rat livers could be attributed to albumin mRNA's present in. the poly (A) RNA fraction.

It can be concluded that there is an increase in albumin mRNA content with age and to a lesser extent a decrease in the translatibility of this mRNA which suggests an age-related increase in albumin synthesis. This increase colncides with the increase in albumin elimination in this rat strain (Horbach et al., 1983; Chapter 10). The mechanism involved in this increase, as well as the possible shortening of the polly(A)-tail with age will be discussed in the next chapter. 


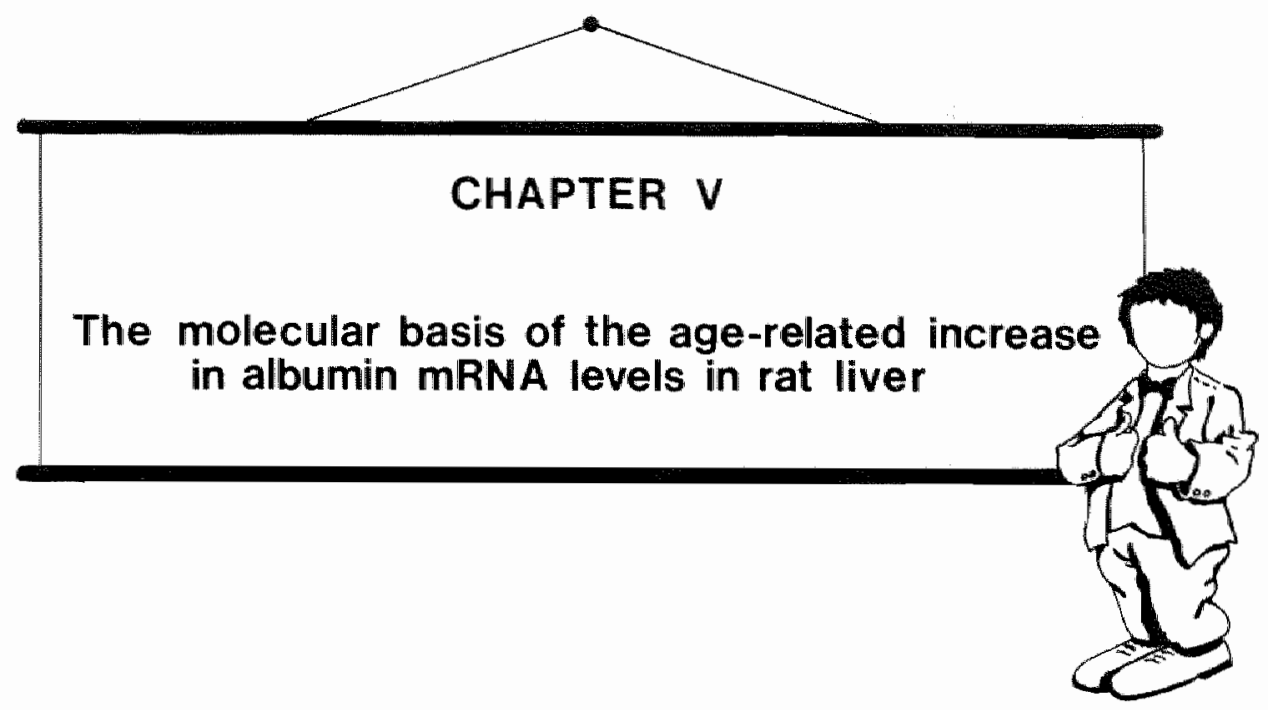

V-1. INTRODUCTION

An age-related increase in the synthesis of rat serum albumin has been reported in several studies (see Chapter IV). In the previous chapter it was shown that the molecular basis of such an increase with age is at the level of the albumin mRNA. Changes in the steady-state levels of a messenger RNA could be due to either of two processes: 1) changes in mRNA synthesis and 2) changes in mRNA turnover. In this chapter studies are presented with regard to the rate of synthesis of this mRNA. In addition, the relative abundance of albumin-specific RNA sequences in the nuclei was determined.

Since the results presented in Chapter IV indicate that a decrease in the length of the poly $(A)$-tail of the albumin mRNA may play an important role in the physiological control mechanism of albumin synthesis, and since the length of the poly $(A)$-tail of mRNA's has been linked with mRNA stability (Brawerman, 1976), additional studies are 
presented with regard to the length of the poly (A)-tails in total cytoplasmic RNA.

\section{V-2. MATERIALS AND METHODS}

$v-2 a$. Animals and materials

The mean weights $\lfloor \pm$ S.D., 15 animals per group】 of the $3-, 12-$, 24- and 36-month-old female WAG/Rij rats were $146 \pm 12,180 \pm 16,242$ \pm 19 and $217 \pm 17 \mathrm{~g}$, respectively. The following chemicals were abtained from the Radiochemical Centre (Amersham, Bucks, UK): $\left(\alpha^{-32} P\right)-$ UTP $(400 \mathrm{Ci} / \mathrm{mmol}),\left(\alpha^{32} \mathrm{P}\right)-\mathrm{dATP}(3000 \mathrm{Ci} / \mathrm{mmol}),\left(\alpha-{ }^{32} \mathrm{P}\right)-\mathrm{dCTP}(3000$ $\mathrm{Ci} / \mathrm{mmol})$, nick translation kits and $\left({ }^{3} \mathrm{H}\right)$-poly(U) $(574 \mathrm{Ci} / \mathrm{mmol})$. Unlabeled deoxyribonucleotides, ribonucleotides, RNase $A$ and RNase $T_{1}$ were obtained from Boehringer (Mannheim, FRG). Bakers yeast tRNA was purchased from Sigma (St. Louis, USA). Poly (A)-markers of defined nucleotide length (average chain lenghts 219, 161, 115 and 51) were obtained from Miles Laboratories (Slough, UK). Other chemicals of a high grade were obtained from standard chemical suppliers.

\section{$\mathrm{V}-2 \mathrm{~b}$. Assays}

1. Determination of the transcriptional activity of the rat albumin gene in isolated nuclei

- Isolation of rat liver nuclei

Rat liver nuclei were isolated using the method of Marzluff and Huang (1984). The liver was perfused with $0.14 \mathrm{M} \mathrm{NaCl} / 10 \mathrm{mM}$ Tris. $\mathrm{HCl}(\mathrm{pH} 8.0)$. The liver was cut into small pieces and homogenized in $0.32 \mathrm{M}$ Sucrose $/ 3.0 \mathrm{mM} \mathrm{CaCl} / 2.0 \mathrm{mM}$ magnesium acetate $/ 0.1 \mathrm{mM}$ EDTA $/ 0.18$ Triton $X-100 / 1.0 \mathrm{mM}$ dithiothreitol/10.0 mM Tris. $\mathrm{HCl} / \mathrm{pH}$ 8.0) $(10 \mathrm{ml}$ per gram of tissuej. The homogenate was filtered through several layers of cheese-cloth to remove connective tissue. The filtrate was then homogenized using a Dounce homogenizer fitted with a tight 
pestlle. The homogenate was diluted with 1 volume of 2.0 sucrose/5.0 $\mathrm{mM}$ magnesium acetate/0.1 $\mathrm{mM}$ EDTA/ $1.0 \mathrm{mM}$ dithiothreitol/10 $\mathrm{mM}$ Tris. $\mathrm{HCl}(\mathrm{PH} \mathrm{8.0)}$ and layered over a cushion of this $2.0 \mathrm{M}$ sucrosebuffer, occupying one third the volume of a centrifuge tube. Centrifugation was performed at $30,000 \times \mathrm{g}$ for $45 \mathrm{~min}$ at $4^{\circ} \mathrm{C}$. The pelleted nuclei were resuspended in $25 \%$ glycerol $/ 5.0 \mathrm{mM}$ magnesium acetate 10.1 $\mathrm{mM}$ EDTA/5.0 $\mathrm{mM}$ dithiothreitol/50 mM Tris. $\mathrm{HCl}(\mathrm{pH} 8.0)$ at a density of $0.5-2 \cdot 10^{8} / \mathrm{ml}$. The nuclei were kept at $-70^{\circ} \mathrm{C}$. The yield of the nuclei was about $50-75.10^{6}$ nuclei per gram of liver.

\section{- Transcription by isolated nuclei}

Rates of RNA transcription by isolated rat iiver nuclei were measured in 12.5 glycerol $/ 5.0 \mathrm{mM}$ magnesium acetate $/ 0.05 \mathrm{mM}$ EDTA/25.0 $\mathrm{mM}$ Tris. $\mathrm{HCl}(\mathrm{pH} \quad 8.0) / 150 \mathrm{mM} \quad \mathrm{KCl} / 2.5 \mathrm{mM}$ dithiothreitol/0.5 $\mathrm{mM}$ ATP/ $0.5 \mathrm{mM}$ CTP/ $0.5 \mathrm{mM}$ CTP/0.025 mM S-adenosy/methionine/0.05 mM $\left(\alpha^{32} P\right)-U T P$, containing $1-4.10^{7}$ nuclei in a total volume of $200 \mu \mathrm{l}$. Incubation was performed at $25^{\circ} \mathrm{C}$. Transcription was monitored by removing aliquots $(1-5 \mu l)$ at the start of the incubation and at several time points. TCA precipitable radioactivity was determined. The reaction was terminated at $45 \mathrm{~min}$. by the addition of 10 volumes of $1 \%$ SDS/10 mM EDTA ( $\mathrm{pH} \mathrm{7.0)}$. One-tenth volume of $2 \mathrm{M}$ sodium acetate $(\mathrm{pH} 5.0)$ was added, followed by an equal volume of water-saturated phenol-chloroform $(2: 1)$. The RNA was extracted at $55^{\circ} \mathrm{C}$ and precipitated with ethanol. The precipitate was dissolved in $0.5 \mathrm{ml}$ of $0.3 \mathrm{M}$ $\mathrm{NaCl} / 0.1 \% \mathrm{SDS} / 1 \mathrm{mM}$ EDTA/10 $\mathrm{mM}$ Tris. $\mathrm{HCl}$ (pH 7.5). The residual unincorporated, labeled nucleotide was removed by chromatography on a column of Sephadex G50. The RNA was recovered by ethanol precipitation.

The determination of the amount of newly synthesised albumin-specific RNA was carried out by hybridizing the $\left({ }^{32} \mathrm{P}\right)-\mathrm{RNA}$ to a specific full-length albumin cDNA probe. The albumin CDNA was cloned and characterized as described by zern et al. (1983). The hybridization was performed according to Marzluff and Huang (1984). Briefly, the cDNA was bolled for $2 \mathrm{~min}$ in $0.2 \mathrm{M} \mathrm{NH}_{4} \mathrm{OH} / 2.0 \mathrm{M} \mathrm{NaCl}$ and then coo- 
led in ice. Five micrograms in $100 \mu \mathrm{l}$ were applied directly to a nitrocellulose filter. The bound DNA was washed in $2 \times 5 S C$ and the filter was baked at $80^{\circ} \mathrm{C}$ for 2 hours. The filters were pre-hybridized at $52^{\circ} \mathrm{C}$ for $30 \mathrm{~min}$ with $0.5 \mathrm{ml}$ of $50 \%$ formamide $/ 5 \times S S C / 0.1 \% \mathrm{SDS} / 1 \mathrm{mM}$ EDTA/10 $\mathrm{mM}$ Tris. HCl (pH 7.5)/10 $\mu \mathrm{g} / \mathrm{ml}$ poly(A)/2xDenhardt (1xDenhardt $=0.028$ Bovine Serum Albumin, $0.02 \%$ Ficoll-400 and 0.028 Polyvinylpyrrolidone $1 / 10 \mu \mathrm{g} / \mathrm{ml}$ denatured salmon sperm DNA (medium A). The pre-hybridization medium was discarded and $0.5 \mathrm{ml}$ of medium $\mathrm{A} /\left({ }^{32} \mathrm{P}\right)-\mathrm{RNA}$ was added. Hybridization was performed at $52^{\circ} \mathrm{C}$ for 72 hours. After hybridization the filters were washed 4 times in $5 x$ SSC/0.1\% SDS/1 mM EDTA/10 mM Tris. HCl $(\mathrm{pH} \mathrm{7.5)} \mathrm{for} 30 \mathrm{~min}$ at $52^{\circ} \mathrm{C}$, once in $0.3 \mathrm{M} \mathrm{NaCl}$ containing $10 \mu \mathrm{g} / \mathrm{ml}$ RNase $A$ for $10 \mathrm{~min}$ at $37^{\circ} \mathrm{C}$, and once in $0.3 \mathrm{M} \mathrm{NaCl}$ at $25^{\circ} \mathrm{C}$. The amount of RNA bound was measured by punching out each dot from the filter and determining the radioactivity by liquid scintillation counting.

2. Determination of the relative abundance of albumin-specific RNA sequences in rat liver nuclei

- Isolation of nuclear and cytoplasmic RNA

Nuclei were prepared by a modification of the citric acid procedure as described by Lamers et al. (1982). Livers were homogenized in 10 volumes of $0.25 \mathrm{M}$ sucrose $/ 75 \mathrm{mM}$ citric acid $(\mathrm{pH} \mathrm{2.3)}$. The homogenate was filtered through several layers of cheese-cloth and Triton $X-100$ was added to a final concentration of $0.5 \frac{0}{2}$. The mixture was layered on a $10 \mathrm{~m} /$ cushion of $1.8 \mathrm{M}$ sucrose/ $25 \mathrm{mM}$ citric acid/0.18 Triton $X-100$ and a $5 \mathrm{ml}$ cushion of $1.0 \mathrm{M}$ sucrose $/ 75 \mathrm{mM}$ citric acid/0.5 Triton $\mathrm{X}-100$. Centrifugation took place at $2,000 \times \mathrm{g}$ for $30 \mathrm{~min}$ at $0^{\circ} \mathrm{C}$. The upper two sucrose layers were collected and re-centrifuged for $30 \mathrm{~min}$ at $20,000 \times \mathrm{g}$ to obtain the cytoplasmic RNA fractions.

The nuclear pellet was suspended in $20 \mathrm{ml}$ of $0.25 \mathrm{M}$ sucrose $/ 10 \mathrm{mM}$ citric acid/0.1 Triton $X-100$ and layered on a $10 \mathrm{ml}$ cushion of $1.0 \mathrm{M}$ sucrose $/ 20 \mathrm{mM}$ potassium acetate $(\mathrm{pH} 4.5) / 0.1 \%$ Triton $X-100$ and centrifuged for $20 \mathrm{~min}$ at $1,000 \times \mathrm{g}$. The pellet was suspended in $0.25 \mathrm{M}$ 
sucrose $/ 20 \mathrm{mM}$ potassium acetate $(\mathrm{pH} 4.5) / 0.19$ Triton $X-100$ and centrifuged for $10 \mathrm{~min}$ at $600 \times \mathrm{g}$. The yield of nuclei was approximately $10^{8}$ nuclei per gram of liver.

The nuclei were dissolved in $4 \mathrm{M}$ guanidinium thiocyanate/0.58 sodium N-lauroy/sarcosine/20 $\mathrm{mM}$ EDTA/0.2 M B-mercapto-ethanol/50 mM PIPES (pH 7.0) (about $5 \mathrm{ml}$ per gram of liver) (Chirgwin et al., 1979). CsCl was added to a final concentration of $1.4 \mathrm{M}$ and this mixture was layered on a $2 \mathrm{ml}$ cushion of $5.7 \mathrm{M} \mathrm{CsCl/0.1} \mathrm{mM}$ EDTA $(\mathrm{pH} 7.0)$ and centrifuged for 18 hours at $150,000 \times \mathrm{g}$ at $25^{\circ} \mathrm{C}$. The pelleted nuclear RNA was dissolved in $10 \mathrm{mM} \mathrm{HEPES} \mathrm{(pH} 7.5$ )/ $1 \mathrm{mM}$ EDTA/0.18 SDS and extracted with chloroform/ isoamyl alcohol (24:1). The yield of nuclear RNA was 50-100 $\mathrm{\mu g}$ per gram of liver.

Cytoplasmic RNA was isolated from the $20,000 \times 9$ pellet. This pellet was dissolved in $2 \mathrm{ml}$ per gram of liver of $5 \mathrm{M}$ guanidinium thiocyanate/0.75\% sodium $\mathbb{N}$-lauroylsarcosine/30 mM EDTA/150 mM $\mathrm{NaHCO}_{3} / 0.3 \mathrm{M}$ B-mercapto-ethanol (Chirgwin et al., 1979). Acetic acid was added to a final concentration of $30 \mathrm{mM}$ and the RNA was precipitated overnight with 1 vol of absolute ethanol at $-20^{\circ} \mathrm{C}$. The RNA was pelleted by centrifugation for $10 \mathrm{~min}$ at $3,000 \times \mathrm{g}$ at $-10^{\circ} \mathrm{C}$ and then dissolved in $1 \mathrm{ml}$ per gram of liver of $7 \mathrm{M}$ guanidinium hydrochloride/20 $\mathrm{mM}$ EDTA/0.2 $\mathrm{M}$ B-mercapto-ethanol $(\mathrm{pH} 7.0)$. Acetic acid was added to a final concentration of $50 \mathrm{mM}$ and the RNA was precipitated with 1 vol of absolute ethanol for 1 hour at $-70^{\circ} \mathrm{C}$. The RNA was pelleted, dissolved in the guanidinium hydrochloride solution, extracted with phenol/chloroform/isaamylalcohol $(50: 49: 1)$ and the RNA was precipitated with absolute ethanol. The yield of cytoplasmic RNA from this procedure was 4 to $5 \mathrm{mg}$ per gram of liver.

- Dot-blot hybridization

Albumin-specific RNA sequences in rat liver nuclear and cytoplasmic RNA were determined by dot-blot hybridization with a specific full-length albumin cDNA probe as described by Thomas (1980) and previously reported by Horbach et al. (1986a). Starting from $\pm 20 \mu g$ RNA, a 1:1 dilution series was made (7 steps) and spotted on a nitro- 
cellulose filter. Hybridization was performed with albumin cDNA which was ${ }^{32}$ p-labeled as described by Rigby et al. (1977). The nitrocellulase filter was pre-hybridized overnight at $42^{\circ} \mathrm{C}$ in $50 \%$ formamide/5x SSC/ $5 \times$ Denhardt $/ 50 \mathrm{mM} \mathrm{NaH}{ }_{2} \mathrm{PO}_{4}(\mathrm{pH} 6.5) / 5 \mathrm{mM}$ EDTA/ $500 \mu \mathrm{g} / \mathrm{ml}$ denatured salmon sperm DNA. Hybridization was carried out for 48 hours at $42^{\circ} \mathrm{C}$ in 508 formamide/5x SSC/ $1 \times$ Denhardt/20 mM NaH $\mathrm{PO}_{4}(\mathrm{pH} \mathrm{6.5)/}$ $5 \mathrm{mM}$ EDTA/250 $\mathrm{\mu g} / \mathrm{ml}$ denatured salmon sperm DNA, containing up to $10 \mathrm{ng} / \mathrm{ml}$ albumin ${ }^{32} \mathrm{P}-\mathrm{cDNA}$. After hybridization the filter was washed twice for 1 hour at $42^{\circ} \mathrm{C}$ in the hybridization mix without the DNA, washed twice for $15 \mathrm{~min}$ at $42^{\circ} \mathrm{C}$ in $2 \times \mathrm{SSC} / 0.1 \% \mathrm{SDS}$ and once for 10 min at $60^{\circ} \mathrm{C}$ in $0.2 \times$ SSC $/ 0.1 \%$ SDS. It was then dried and autoradiographed at $-80^{\circ} \mathrm{C}$ on a KODAK-X-omat film using a Du Pont intensifying screen.

3. Size determination of poly $(A)$-tails of rat liver cytoplasmic RNA

Size determination of poly $(A)$-tails was performed according to SalaTrepat et al. (1978) with slight modifications. $1 \mathrm{mg}$ of total cytoplasmic RNA, isolated as described above, was dissolved in $500 \mu / 0.4 \mathrm{M}$ $\mathrm{NaCl} / 10 \mathrm{mM}$ Tris. $\mathrm{HCl}(\mathrm{pH} 7.5) / 5 \mathrm{mM}$ EDTA and digested with $50 \mathrm{ug}$ RNase $A$ and 300 units RNase $T_{1}$ at $37^{\circ} \mathrm{C}$ for $30 \mathrm{~min}$. The reaction was stopped by the addition of $15 \mu$ ldiethylpyrocarbonate. $100 \mu \mathrm{g}$ of E.Coli tRNA was added, followed by precipitation with ethanol.

The poly(A)-fragments were separated on the basis of size by electrophoresis on 2.58 polyacrylamide gels containing $0.5 \%$ agarose. Gels were run for 2 hours at $5 \mathrm{~mA} / \mathrm{gel}$. After electrophoresis was stopped, the gels were frozen and cut into $1 \mathrm{~mm}$ slices. Three adjacent slices were collected and placed in $1 \mathrm{ml}$ of $0.3 \mathrm{M} \mathrm{NaCl} / 30 \mathrm{mM}$ trisodium citrate $(\mathrm{pH} 6.8)$ and the poly(A) was eluted overnight at room temperature. The poly(A) content was determined by molecular hybridization with $\left({ }^{3} \mathrm{H}\right)$-poly $(U)$.

Hybridization reactions were carried out in $1 \mathrm{ml}$ of $10 \mathrm{mM}$ Tris. $\mathrm{HCl}$ (pH 7.6)/0.2 M NaCl containing 75-250 pl of the poly(A) solution and 
$0.025 \mu \mathrm{Ci}\left({ }^{3} \mathrm{H}\right)$-poly $(U)$. The samples were incubated for $30 \mathrm{~min}$ at $30^{\circ} \mathrm{C}$, and $10 \mu \mathrm{l}$ of a RNase A solution $(31.25 \mu \mathrm{g} / \mathrm{ml})$ was then added. After another incubation for $30 \mathrm{~min}$, the samples were chilled, carrier tRNA $(30 \mu \mathrm{g})$ was added and the mixtures were precipitated with $3 \mathrm{ml}$ of $7 \%(w / v)$ TCA. The precipitated radioactivity was determined in a liquid scintillation counter.

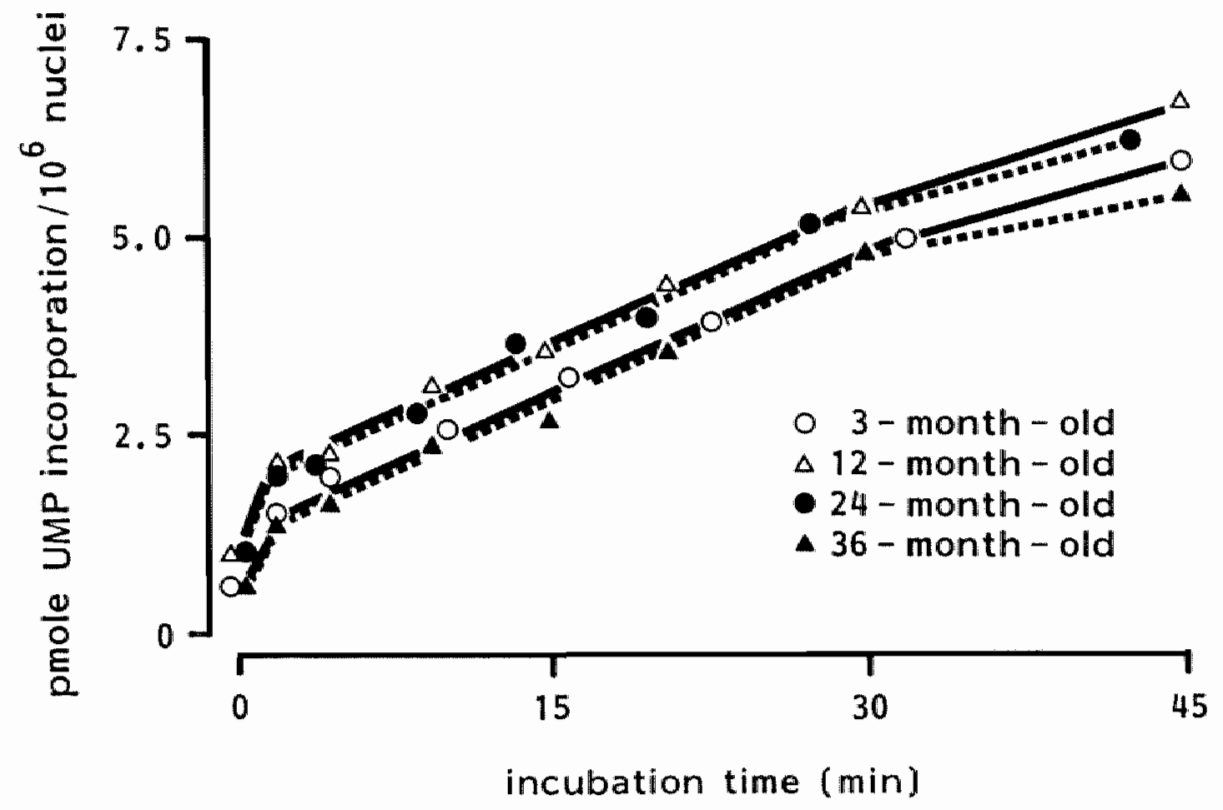

Fig. V-1. Time curves for incorporation of $\left({ }^{32} \mathrm{P}\right)$ - (WP in isolated liver muellef of rats of various ages. Mean curwes are shown. The standard deviation was lom than 15 .

The gel pattern obtained in this way was corrected for the length of the poly(A)-tails using the equation:

$$
\left(\mathrm{cpm}_{\mathrm{cor}}\right)_{\mathrm{i}}=\frac{(\mathrm{cpm})_{\mathrm{i}}}{\mathrm{Li}}
$$




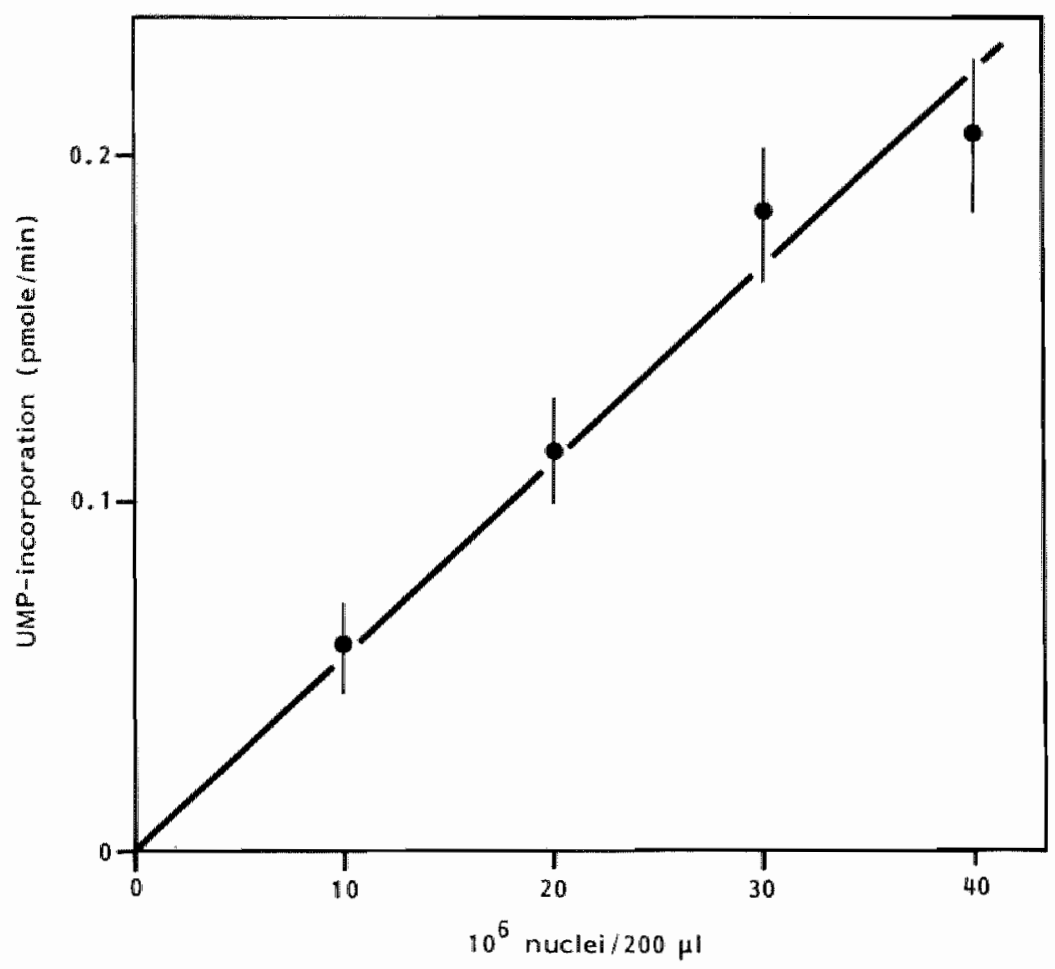

Fig. V-2. Relationship between the amount of nuclei and the incorporation of $1^{32}$ p)-ump per min. The data shown are obtained with 3 -month-old rat liver muclei. The wlues represent the means and the standard error of the mean.

where $\left(\mathrm{cpm} \mathrm{cor}_{i}\right)_{i}$ is the corrected radioactivity in fraction $i,(\mathrm{cpm})_{i}$ is the measured radioactivity in fraction $i$, and $L_{i}$ is the length in nucleotides in fraction $i$ (as determined from the marker gels).

\section{$V-3$. RESULTS}

$V-3 a$. The transcriptional activity of the rat albumin gene with age

In the nuclear run-off assay, incorporation of $\left({ }^{32} \mathrm{P}\right)-\mathrm{UMP}$ into nascent RNA chains proceeded linearly for at least $30 \mathrm{~min}$ at $25^{\circ} \mathrm{C}$ after 
an initial phase of $1-2 \mathrm{~min}$ (Fig. $V-1$ ) and was also linear with the amount of nuclei used (Fig. $V-2$ ). Nuclei were essentially free of cytoplasmic contamination as judged by electron microscopy (Fig. $V-3$ ). No influence of age was observed in the total transcriptional activity of the isolated nuclei (Fig. $V-1)($ Table $V-1)$.

Table $V-1$ EFFECT OF AGE ON THE RATE OF SYNTHESIS OF TOTAL RNA AND ALBUMIN-SPECIFIC RNA BY ISOLATED RAT LIVER NUCLEI

Age

(months)

3

12

24

36
RNA synthesis rate

C. pmole UMP/h. $10^{6}$

nuclei)

$6.86 \pm 0.83$

$7.02 \pm 0.77$

$6.75 \pm 0.89$

$6.56 \pm 0.90$
Albumin RNA synthesis rate $(p p m)^{+}$

$286+25$

$302 \pm 19$

$300 \pm 24$

$329 \pm 31$

"The synthesis rates are expressed as parts per million (ppm) and were derived from the ratio of hybridized radioactivity and total input radioactivity. Values are corrected for 438 hybridization efficiency as determined by the hybridization of known amounts of albumin mRNA in a parallel reaction. Values are expressed as means \pm S.D. for 5 experiments.

The specific transcriptional activity of the albumin gene was assessed by hybridizing the radiolabeled nuclear transcripts to filter bound full-length albumin CDNA. The data in Table $V-1$ indicate that the transcriptional activity of the albumin gene is not influenced by age. 


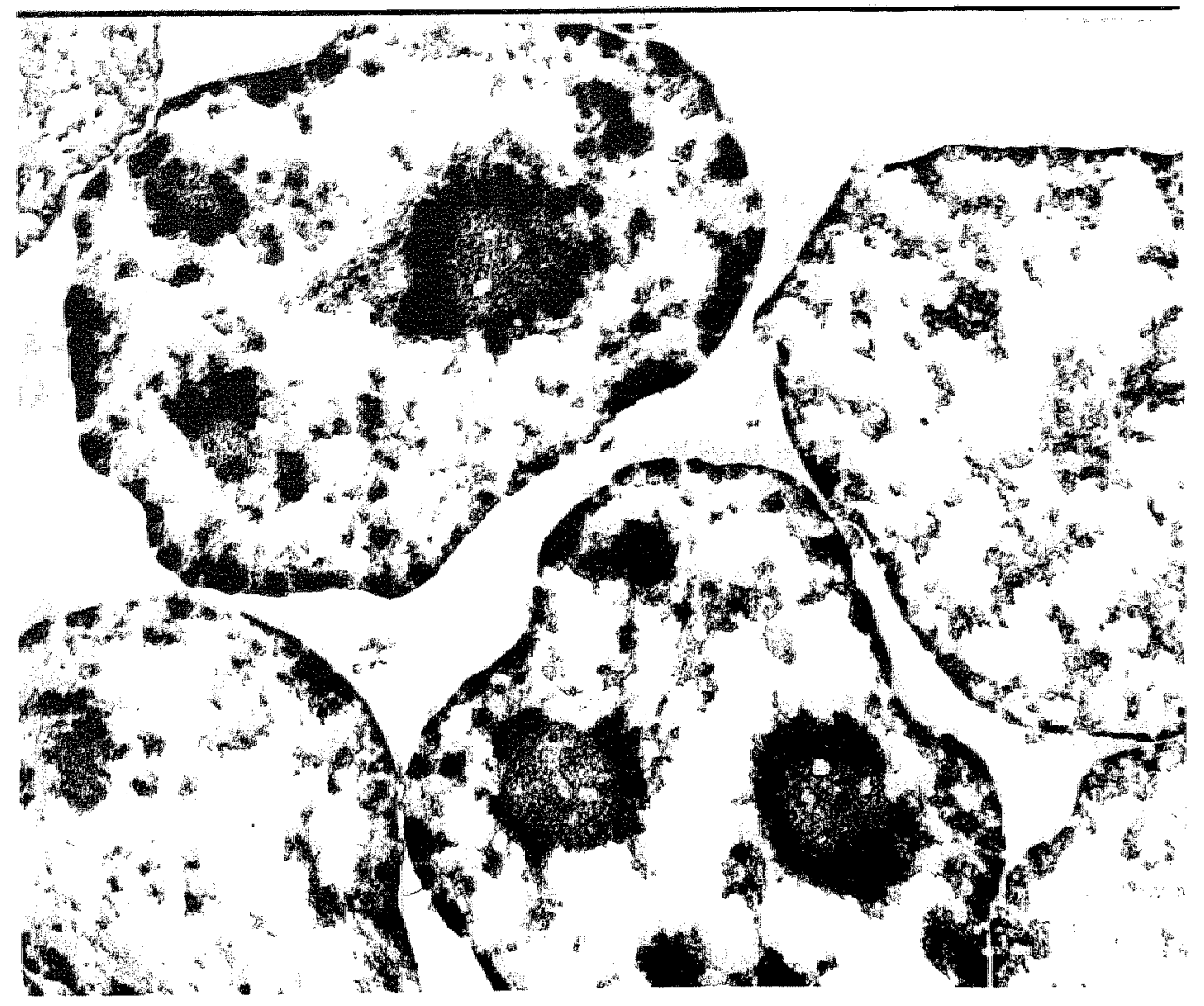

Fig. V-3. Transmission election milcrograph of isolated rat liwer nucleü. The nuclei were used for in witro transcriptional experiments and were obtained as described in the "mater"ils and methods" section ( $V-2 b .1)$.

$V-3 b$. The relative abundance of albumin-specific $\mathbb{R} N A$ sequences in rat liver nuclet

The amounts of albumin RNA sequences in rat liver nuclei were determined by dot-blot hybridization. Nuclei were free of cytoplasmic contamination as judged by electron microscopy (Fig. V-4). After hybridization, the bound radioactivity was determined and used as a measure of the relative amount of albumin $\mathrm{RNA}$ (Fig. $\mathrm{V}-5$ ). The results are shown in Table $V-2$. In the cytoplasmic fraction an increase in allbumin mRNA at between 12 and 24 months of age was observed. This 


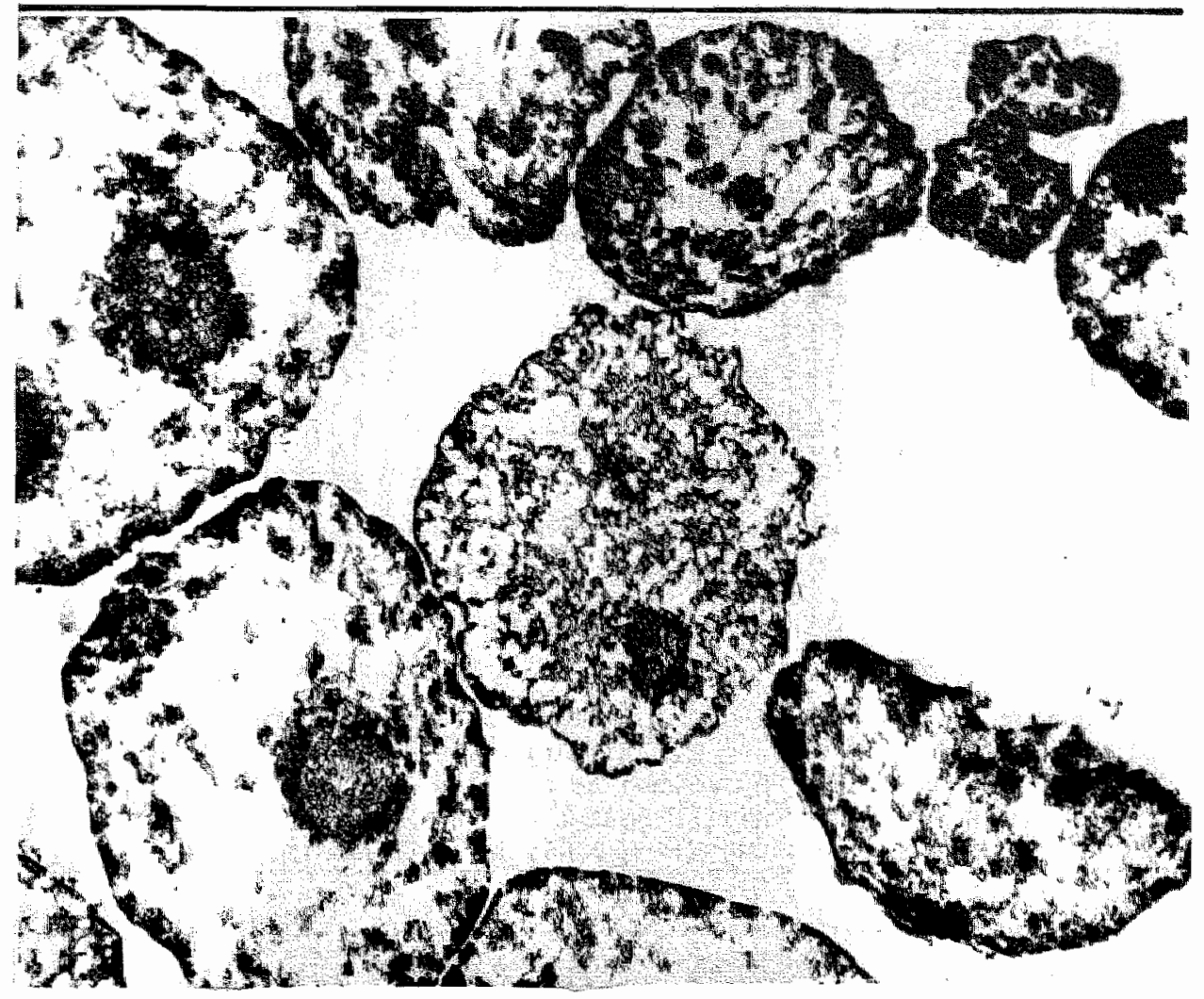

Fig. V-4. Transmission electron micrograph of isolated rat liver nuclei. The nuclei were used for the isollation of nuclear RNA and were obtained as described in the "Materials and methods" section $(V-2 b .2)$.

finding is consistent with previous findings (Horbach et al. , 1984a; Chapter IV). In nuclear RNA there was no agemelated change in albuminn RNA content.

$V-3 c$. The size of poly $(A)$-tails in total cytoplasmic RNA isolated from rat liver

The size of poly (A)-tails in total cytoplasmic RNA was determined by electrophoresis in $2.5 \%$ polyacrylamide/ $0.5 \%$ agarose gels. 
Table $V-2$ AGE-RELATED CHANGES IN ALBUMIN-SPECIFIC RNA SEQUENCES IN RAT LIVER NUCLEI AND CYTOPLASM

Relative abundance of albumin RNA in nuclei as compared to nuclear RNA of 3 -month-old rats

Age

nuclei

cytoplasm

(months)

3

12

24

36
1 *

$1.09 \pm 0.15$

$0.93 \pm 0.12$

$1.01 \pm 0.17$
$16.2 \pm 2.3$

$15.6 \pm 2.6$

$31.8 \pm 4.7^{a, b}$

$33.1 \pm 4.2^{a, b}$

* The amount of albumin RNA in nuclear RNA of 3-month-old rats has been arbitrarily set to 1 . Other values are expressed relative to this unit. Values are expressed as means \pm S.D. for 5 experiments. a: value differs significantly $(P<0.05)$ from 3 -month value. b: value differs significantly $(P<0.05)$ from 12 -month value.

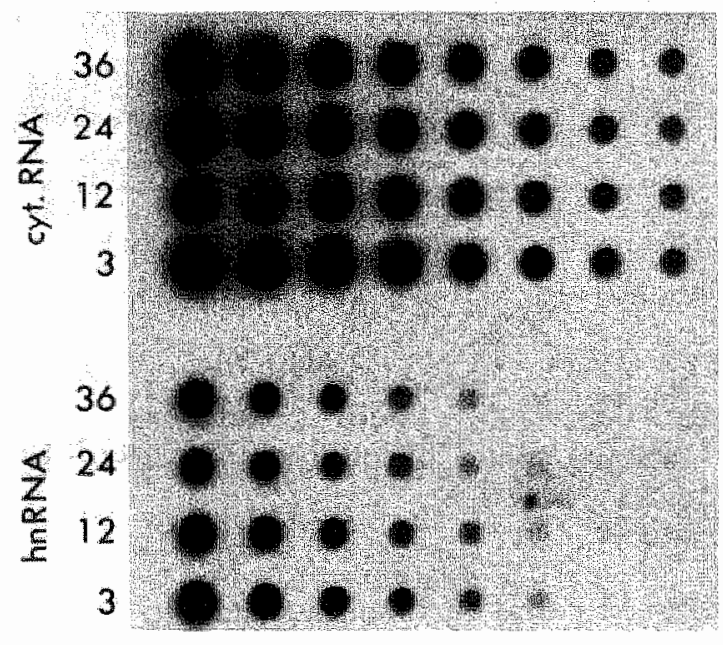

Fig. V-5. Dot-blot hybridization of albumin ${ }^{32}$ P)-cDNA to total cytoplasmic RNA (cyt RNA) and total nuclear RNA (hnRNA) isolated fram livers of rats of various ages. 
Calibration of these gels was performed using poly(A) markers of known length (Fig. $V-6$ ). From these marker gels, a calibration graph was constructed of the log of the length of the marker poly(A)'s against distance of migration (Fig. $V-7$ ). Figure $V-8$ shows the size distribution of the poly(A)-tails from cytoplasmic RNA from a 3-monthold rat together with the corrected gel pattern (see materials and methods). From the individual corrected gel patterns and the calibration graph (Fig. $V-7$ ), the length of the poly (A)- tail sedimenting at the peak fraction in each age-group was determined, as was the overall poly(A)-tail length distribution. From Table $V-3$ it can be seen that there is no change with age in the length of the poly(A)-tail sedimenting at the peak fraction. However, the results presented in Table $V-4$ show an age-related shift in the overall distribution of the poly $(A)$ tails. The relative amount of poly $(\mathrm{A})$-tails longer than 161 A-residues is decreased between the ages of 12 and 24 months, whereas the amount of poly (A)-tails shorter than 115 A-residues is increased between these two ages.

\section{V-4. DISCUSSION}

RNA synthesis has been studied as a function of age in isolated rat liver nuclei by several groups (Gibas $\&$ Harman, 1970; Denckla, 1977; Castle et al. 1978; Bolla \& Denckla, 1979; Lindell et al., 1982). Apart from the study of Gibas \& Harman (1970), who observed no change with age in RNA synthesis, all other reports indicated an age-related decline in this process. In the present study. RNA synthesis by isolated rat liver nuclei appeared unaffected by age. The difference between these results and literature data may be explained by the use of different rat strains. The rate of transcription of the albumin gene was assessed by hybridization of the labeled RNA molecules with filterbound albumin CDNA. The results in Table $V-1$ show an albumin-gene 
Fig. V-6. Polyacrylamide/agarose gel electophoresis of paly( A)-merkers. Poly(A)-content in 3 mestices was determimed by molecular trybridization with $(3 \mathrm{H})-p o l y(U)$. Wigration is from left to right.

transcription rate of about 300 p.p.m. This result is in accordance wilth the results obtained by Meisner et al. (1983). It can be seen that aging seems nat to influence the transcriptional rate of the albumin gene (Table $\mathrm{V}-1$ ).

The studies concerning the amount of albumin-specific RNA in rat liver nuclei revealed no age-related changes (Table $V-2$ ), although a two-fold increase in the albumin mRNA content in the cytoplasm could be observed at between the ages of 12 and 24 months (Table $V-2$ ). This confirms the findings presented in Chapter IV obtained with a different method (fluid hybridization). The observation, that the amount of albumin RNA sequences relative to total RNA in young rats.

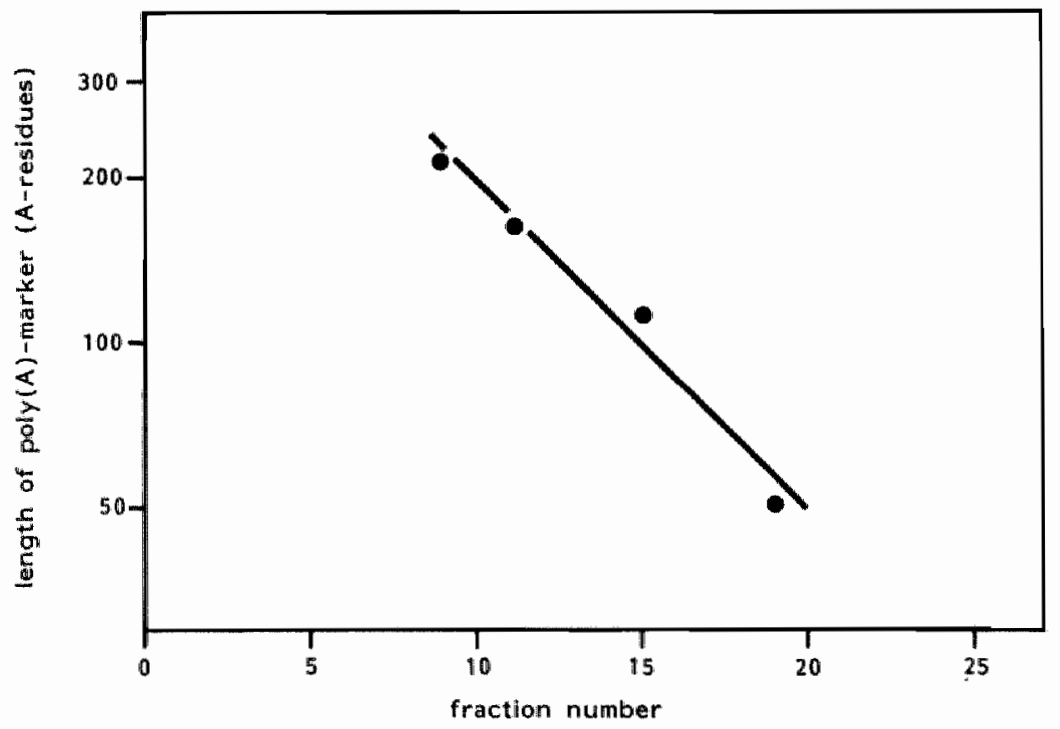

Flg. W-7. Relationship between the loganthm of average chain length and the mobilitity of the poly(A)-marker. 


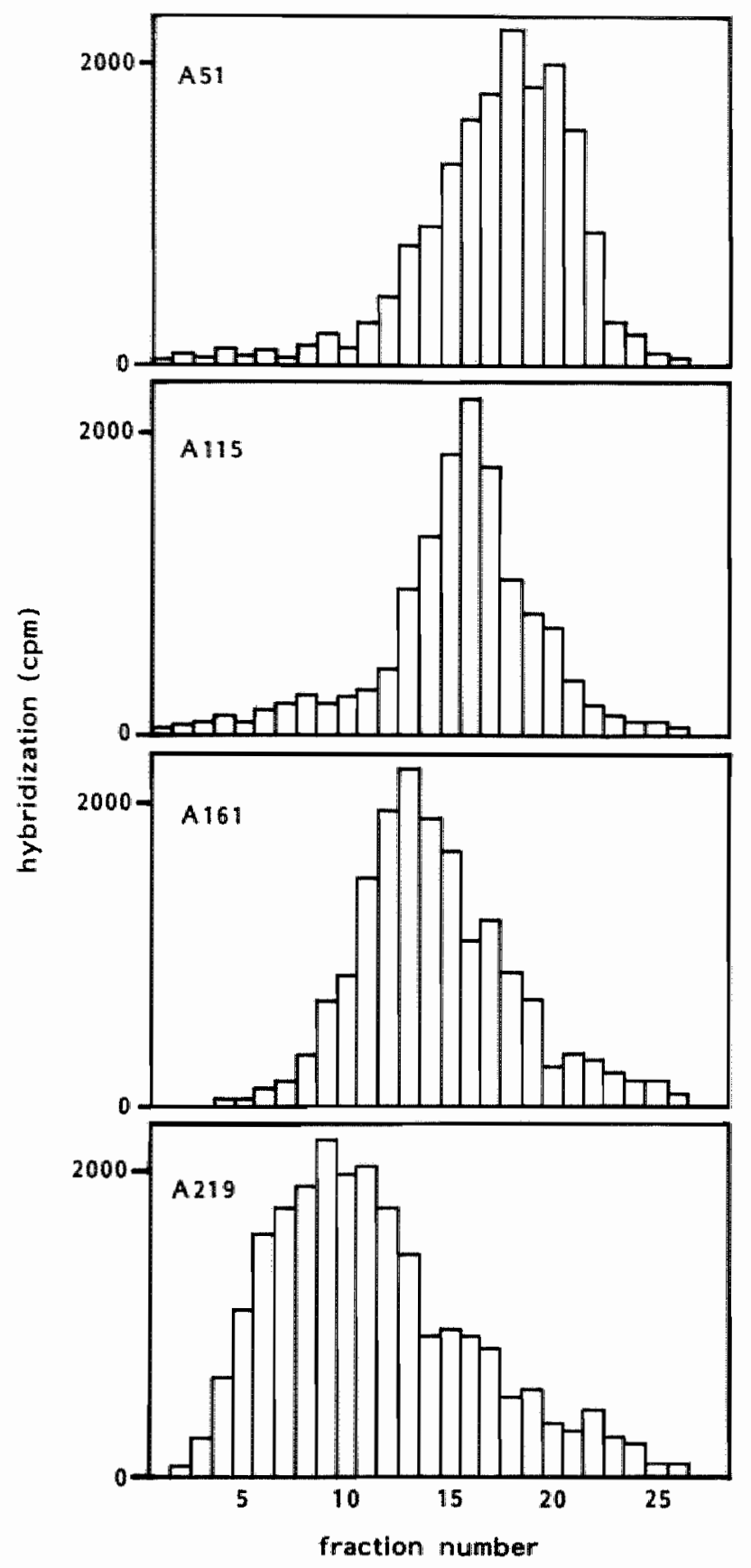



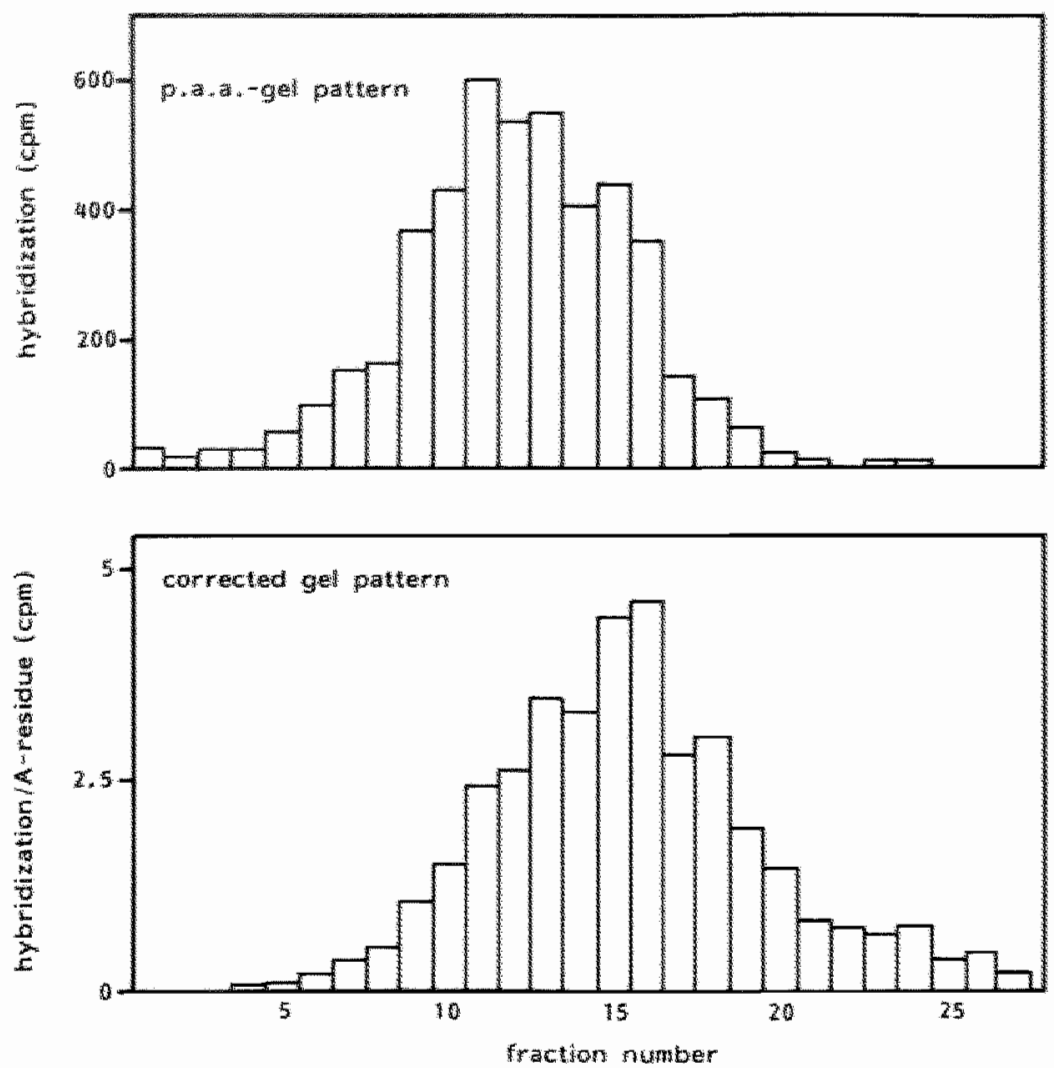

Fig. V-B. Polyacryamidefagrose gel electrophorests of polyth-segments isolated from cytoptastic Ra from liver of 3-nonthold rat The woper pare shows the padagerose patern; the lower panel shows the corrected pattern.

is appromimately 16 -fold higher in the cytoplasm than in the nuctei. compares well with the findings of Guertin et al. (1983).

These results suggest that the increase in albumin mRMA content in rat liver with age is not controlled by transcriptional processes, but might be caused by a decreased turnover of this mRNA. The length of the poly $(A)$ - tall plays an impatant role in maintaining the stability of mRNA (Brawerman, 1976). The results presented in Chapter IV indica- 
ted a relative shortening or loss of the poly( $A)$-tail of the albumin mRNA with age. In this chapter the influence of age on the poly(A)-

Table $W-3$ THE INFLUENCE OF AGE ON THE SIZE-DISTRIBUTION OF POLY(A)-TRACTS OF RAT LIVER MRNA

Age

[months]
Length of polly $(A)$ -

tract in peak fraction

(number of $A$-residues)
3

12

24

36

$$
\begin{aligned}
& 131 \pm 12 \\
& 137 \pm 10 \\
& 128 \pm 17 \\
& 125 \pm 23
\end{aligned}
$$

Values are expressed as means \pm S.D. for 5 experiments

tails of total cytoplasmic RNA has also been studied. The length of the poly(A)-tail sedimenting at the peak fraction was shown to be about

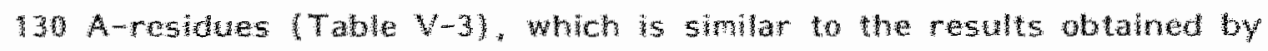

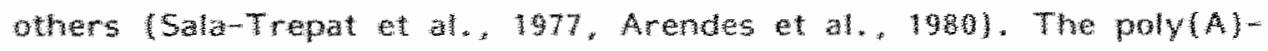

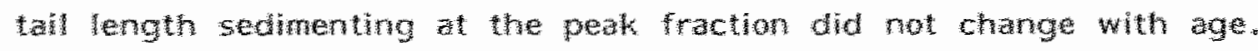
On the other hand. there was a signifcant shrt wh age in the over-

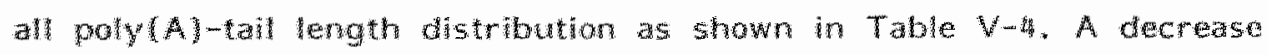

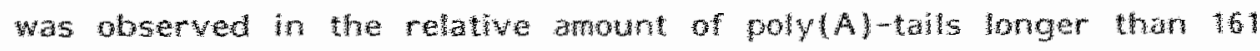
A-residues bewwer the ages of 2 and 24 morths logether whith an-

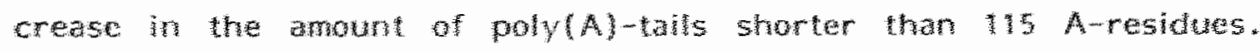

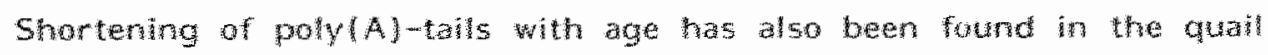

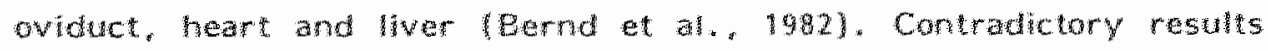


were obtained by Birchenall-Sparks et al. (1985) who showed that the poly $(A)$ - tail length of mRNA's isolated from rat hepatocytes was not affected by age. However, the short mean size they found in their ex-

Table $V-4$ THE INFLUENCE OF AGE ON THE SIZE-DISTRIBUTION OF POLY (A)-TRACTS OF RAT LIVER MRNA

Age (months) 3

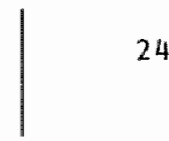

36

Length of

poly $(A)$ - Percentage of poly $(A)$ tracts of a defined length ( $\%)$

tracts

(number of

A-residues)

\begin{tabular}{rrl|r|r|r|r}
$>216$ & $3.10 \pm 0.21$ & $2.89 \pm 0.22$ & $1.07 \pm 0.16^{\mathrm{a}, \mathrm{b}}$ & $1.02 \pm 0.19^{\mathrm{a}, \mathrm{b}}$ \\
$161-216$ & 23.9 & \pm 2.6 & $26.2 \pm 3.4$ & $9.92 \pm 0.85^{\mathrm{a}, \mathrm{b}}$ & $8.27 \pm 0.98^{\mathrm{a}, \mathrm{b}}$ \\
$115-161$ & 38.4 & \pm 1.7 & 37.9 & \pm 4.0 & $39.3 \pm 3.7$ & $40.9 \pm 4.7$ \\
$51-115$ & 25.6 & \pm 3.2 & $22.2 \pm 2.8$ & $30.3 \pm 2.4^{\mathrm{a}, \mathrm{b}}$ & $32.3 \pm 3.9^{\mathrm{a}, \mathrm{b}}$ \\
$<51$ & 9.0 & \pm 1.2 & 10.8 & \pm 1.5 & $21.1 \pm 3.1^{\mathrm{a}, \mathrm{b}}$ & $17.5 \pm 1.7^{\mathrm{a}, \mathrm{b}}$
\end{tabular}

Values are expressed as means \pm S.D. for 5 experiments a: value differs significantly $(p<0.05)$ from 3 -month value $b$ : value differs slgnificantly $(p<0.05)$ from 12 -month value

periments (70 A-residues), might indicate breakdown of the tall during the isolation procedures.

When the results presented in this chapter are compared with those presented in Chapter IV, an interesting phenomenon is observed. Although a shortening of the poly(A)-tail with age has been found for total cytoplasmic RNA (Table $V-4$ ), this is not refiected in the amount of total poly $(A)^{+}-\mathrm{RNA}$ as determined by oligo(dT)-cellulose chromato- 
graphy (Table IV-1). On the other hand, a marked shift in the relative amount of albumin mRNA towards the poly(A) ${ }^{-}$- RNA fraction with age was observed. This would indicate that the poly $(A)$-tail length of total cytoplasmic RNA is less affected by aging than that of albumin mRNA. How a shortening of the poly (A)-tail can be reconciled with an increase in albumin mRNA stability is presently unknown. Whether there are other mRNA stabilizing factors remains to be established. 


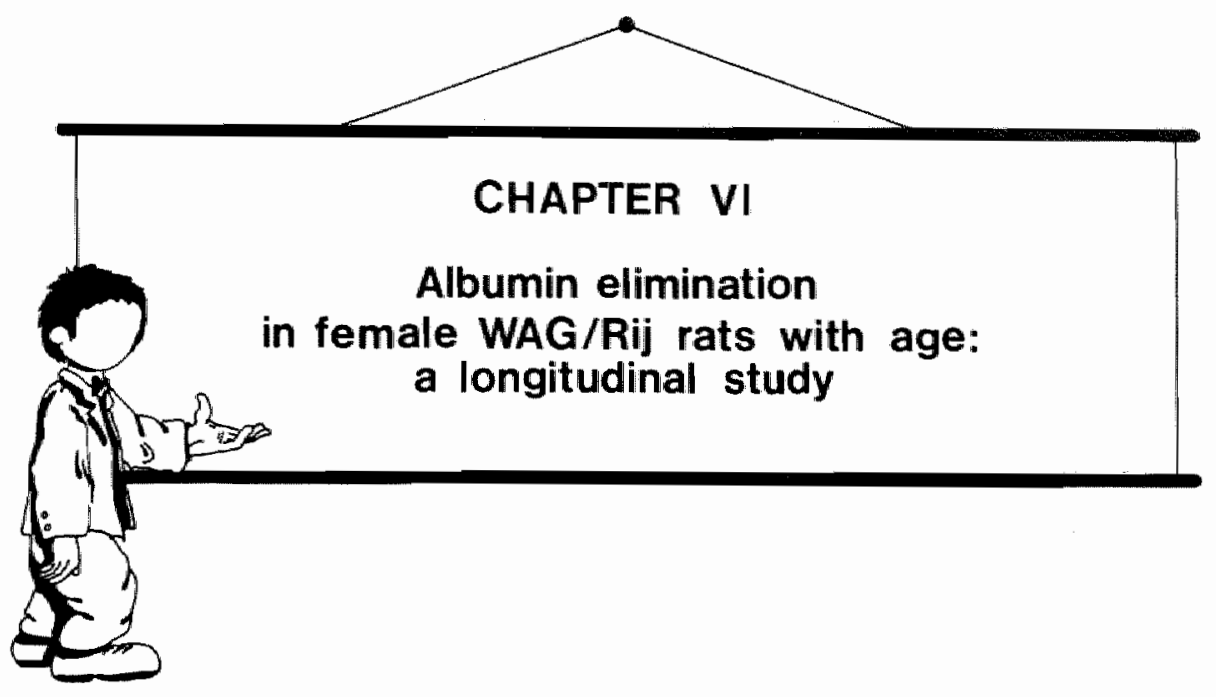

VI-1. INTRODUCTION

In Chapter 11, it was shown that the absolute albumin elimination rate in female WAG/Rij rats increased with age. An increase was found between 12 and 24 months of age, which was due only to changes in the physiology of the animals. The increase which was abserved between 24 and 36 months of age was mainly due to changes in the albumin molecule. Concomitant with these changes an age-related increase in the urinary albumin excretion was found, but this could not account for the increase in total albumin elimination in this rat strain.

Crass-sectional studies (such as those performed and described in Chapter II) have the disadvantage that they do not exclude cohort effects upon the parameter being studied. In order to ascertain the influence of aging per se on certain functions, it would be appropriate to study how those functions changed with time in individual animals. 
It would then be possible to see if aging exerts a uniform effect on all individuals.

In this chapter, a longitudinal study on albumin ellimination will be described. By comparing these results with those from the cross-sectional study (Chapter II), information will be gathered on those changes in this elimination process that are caused by aging alone.

\section{VI-2. MATERIALS AND METHODS}

VI-2a. Animals and materials

The experiment commenced with 30 female WAG/Rij rats. The mean weight $[ \pm$ S.D.] of these 3 -month-old animals was $136 \pm 17 \mathrm{~g}$.

DEAE Affi-Gel Blue was obtained from Bio-Rad Laboratories (Richmond, CA, USA). Goat anti-(rat total serum proteins) antiserum used for immunoelectrophoresis (CARa/ielfo) and rabbit anti-(rat serum albumin) antiserum (RARa/Alb) were obtained from Nordic Immunological Laboratories (Tilburg. The Netherlands). ${ }^{125}$ I was abtained from the Radiochemical Centre (Amersham, Bucks, UK).

VI-2b. Assays

1. Albumin isolation, purification and labeling with ${ }^{125}$,

The isolation and purification of albumin was achieved by chromatography of fresh rat serum on DEAE Affi-Gel Blue as described by Horbach et al. (1983) (Chapter II, section II-2b.1.).

The isolated rat serum albumin was iodinated by the method of McFarlane (1956) as modified by Helmkamp et al. (1967) to a final ratio of 1 mole of $1251 /$ mole of albumin.

2. Plasma radioactivity curves

lodinated albumin $(5 \mu \mathrm{Ci})$ was injected intravenously into the ex- 
ternal jugular vein of the rats at $3,12,24$ and 36 months of age. Trichloroacetic acid-precipitable radioactivity was determined in $20 \mu 1$ aliquots of plasma at several time points over 5 days. From the plasma radioactivity curves, the following characteristics were calculated:
a) Elimination half-life: $t_{\frac{1}{2},}, \mathrm{el}$
b) Apparent volume of distribution: $\mathrm{Vd}$
c) Clearance: $\mathrm{Cl}$

These characteristics were calculated as described in Chapter $\|$ (section $11-2 b .2$.$) .$

3. Plasma albumin concentration, plasma protein concentration, the whole-body albumin pool and the absolute rate of albumin elimination

The albumin concentration in plasma was determined by radial immunodiffusion as described by Mancini et al. (1965), as modified by Radl et al. (1970). With the use of the plasma albumin concentration, the data for apparent volume of distribution and clearance can be extrapolated in terms of the whole-body albumin pool and the absolute rate of albumin elimination as described in Chapter II (section II-2b.3.).

The protein concentration in plasma was determined by the method of Lowry et al. (1951).

4. Urinary albumin and total protein excretion

Animals were kept in metabolic cages for 24 hours and supplied with water and food ad libitum. The urine was collected and the amount of albumin excreted was determined by radial immunodiffussion as described by Mancini et al. (1965) and modified by Radl et al. (1970). The amount of total protein excreted was determined by the method of Lowry et al. (1951), as modified by Bensadoun \& Weinstein (1976). 
5. Quantitative determination of the total liver RNA content and the albumin mRNA content

From the livers of the rats that reached the age of 36 months, total post-nuclear RNA was isolated according to the method of Taylor $\varepsilon$ Schimke (1973)(section $\| V-2 b .1$.$) . The RNA content was determined by$ the method of Fleck \& Munro (1962) (section IV-2b.6.). Albumin mRNA quantitation was performed by analytical RNA-cDNA hybridization as described by Housman et al. (1974) (section IV-2b.11.).

\section{Histology}

Complete necropsies were performed on all the animals in this study. Most animals died spontaneously, some were killed in extremis. and animals which survived to 36 months of age were killed at that time. Tissue specimens were fixed by immersion in $10 \%$ buffered formalin, embedded in paraffin by standard methods, sectioned at 3 um. and stained with hematoxyline-phloxine-saffion (HPS). A few specimens were sectioned at $2 \mu \mathrm{m}$, and stained with PASM-Azan to demonstrated basement membranes. The following tissue specimens were routinely examined by light microscopy: skin, salivary glands, mammary gland, lung, heart, esophagus and all segments of the gastrointestinal tract, liver, pancreas, kidney, urinary bladder, ovary, uterus, vagina, preputial gland, spleen, thymus, longitudinal section of the femur and sternum and their associated bone marrow, trachea, thyroid, adrenals, pituitary, brain and meninges, and cervical, inguinal, axillary, mediastinal, and mesenteric lymph nodes. Four cross-sections through the head were also examined.

Kidney sections were examined without knowledge of the age of the animal or the amount of measured urinary protein or albumin. The renal lesions were classified according to severity (Gray et al., 1982) and this is explained in section $V /-3 d$. If there was any dissimilarity in the score between individual kidneys, the animal was placed in the higher of the two numerical categories. 
Statistical calculations with regard to the characteristics measured in the longitudinal study were carried out using Student's t-test for correlated groups.

The correlation between the amount of protein or albumin in the urine and the histological score of the severity of renal lesions was calculated using Spearman's rank correlation coefficient (Snedecor and Cochran, 1980). Animals that died more than 16 weeks following the last determination of urinary protein were not included in the statistical analysis.

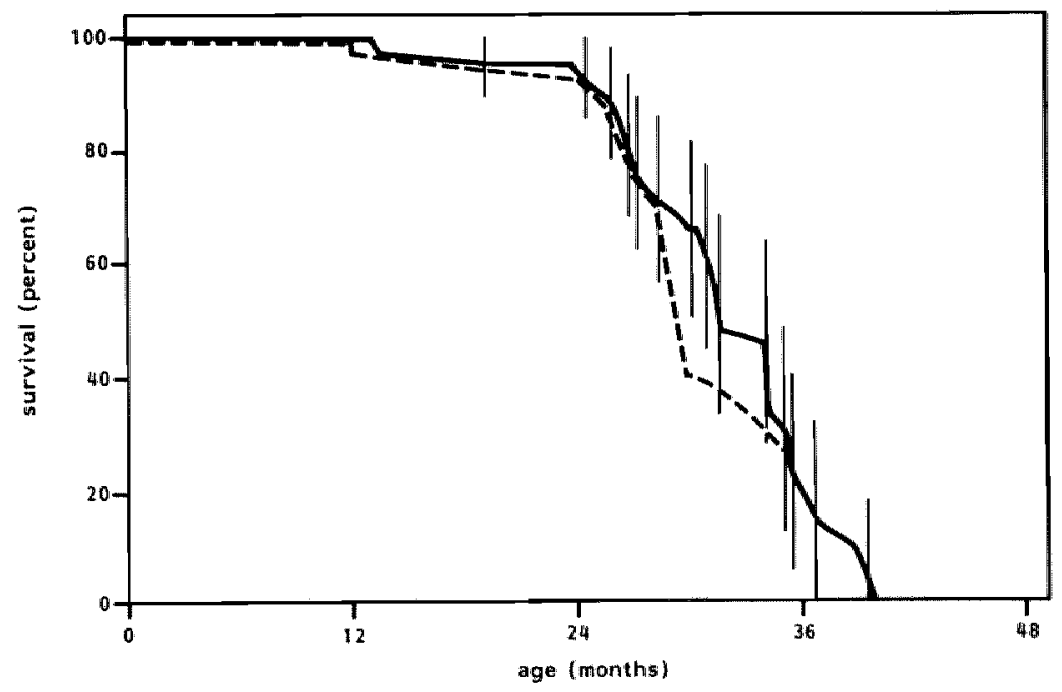

Fig. VI-1. Survival curves of female HAG/Rij rats

..... 30 rats used in this stuidy

- 50 rats fram 3 separate cohorts, born in the same periad as the rats used in this study. The vertical bars represent the $95 \%$ confidence limits. 
V1-3a. Survival characteristics of the rats used in this study

The study started with 303 -month-old rats. Up to 24 months of age the death rate of these rats was very low. Only 3 rats had died during the first two years of this study. After 24 months of age the death rate progressively increased. By 30 months of age only 12 animals remained, and only 6 remained at 36 months of age. The precise details of the survivall of this group of animals is depicted in Figure VI-1. A survival curve for a control group of 50 female WAG/Rij rats from 3 different cohorts is also shown for comparison.

It is clear than the survival characteristics for this rat strain are faithfully reflected in the group used in this study.

$V \|-3 b$. The influence of age on the measured characteristics

\section{- Body weight}

The mean body weights for the rats at $3,12,24,30$ and 36 months of age are shown in Table $V I-1$. There is an increase in body weight for all rats between 3 and 12 months of age as well as between 12 and 24 months of age. Between 24 and 30 months of age the body weight does not significantly change. At 36 months of age, all of the six survivors had a lower body weight compared to the values obtained at 24 and 30 months of age.

- Plasma volume

The mean values for plasma volume are shown in Table VI-1. The plasma volume is seen to increase between 3 and 12 months of age, to remain constant between 12 and 24 months of age and to increase again between 24 and 36 months of age.

- Elimination half-life of albumin

The elimination half-life was determined for albumin isolated from 3- 
Table VI-1. THE INFLUENCE OF AGE ON THE BODY WEIGHT AND

PLASMA VOLUME OF FEMALE WAG/RIj RATS

$\begin{array}{cccc}\text { Age (months) } & N & \text { Body weight }(\mathrm{g}) & \begin{array}{c}\text { plasma volume } \\ (\mathrm{ml})\end{array} \\ 3 & 30 & 136 \pm 17 & 6.1 \pm 0.5 \\ 12 & 29 & 192 \pm 12^{\mathrm{a}} & 6.6 \pm 0.5^{\mathrm{a}} \\ 24 & 27 & 219 \pm 35^{\mathrm{a}, \mathrm{b}} & 6.8 \pm 1.4^{\mathrm{a}} \\ 30 & 12 & 209 \pm 25^{\mathrm{a}, \mathrm{b}} & \mathrm{N} . \mathrm{D} . \\ 36 & 6 & 199 \pm 19^{\mathrm{a}, \mathrm{c}} & 7.3 \pm 0.8^{\mathrm{a}, \mathrm{b}, \mathrm{c}}\end{array}$

Values are expressed as means $\pm S$. D.

$N$ : the number of animals

a: value differs significantly $(P<0.05)$ from 3 -month value

$b$ : value differs significantly $(P<0.05)$ from 12 -month value

c: value differs significantly $(P<0.05)$ from 24 -month value

N.D.: not determined

Table VI-2 THE INFLUENCE OF AGE ON THE ELIMINATION HALFLIFE OF ALBUMIN IN FEMALE WAG/Rij RATS

Age (months) N

N Elimination half-life $(h)$

Albumin from age-matched

3-month-old rats albumin

$\begin{array}{rrll}3 & 30 & 45.3 \pm 6.5 & 45.3 \pm 6.5 \\ 12 & 29 & 44.9 \pm 4.5 & 40.4 \pm 3.6 \\ 24 & 27 & 38.5 \pm 3.1^{a}, b & 37.3 \pm 3.9^{a} \\ 36 & 6 & 37.1 \pm 3.3^{a}, b & 41.5 \pm 4.6\end{array}$

Values are expressed as means \pm S.D.; $\mathbb{N}$ : the number of animals

a: value differs significantly $(P<0.05)$ from 3 -month value

$b$ : value differs significantly $(P<0.05)$ from 12 -month value 
month-old rats and for albumin isolated from rats of the same age as the recipient. The mean values are shown in Table VI-2. After injection of age-matched albumin, the elimination half-life was shown to be lower at 24 months of age than that at 3 months of age. A significant decrease in $t_{\frac{1}{2}}$, el could be observed at between 12 and 24 months of age when albumin from 3 -month-old rats was injected.

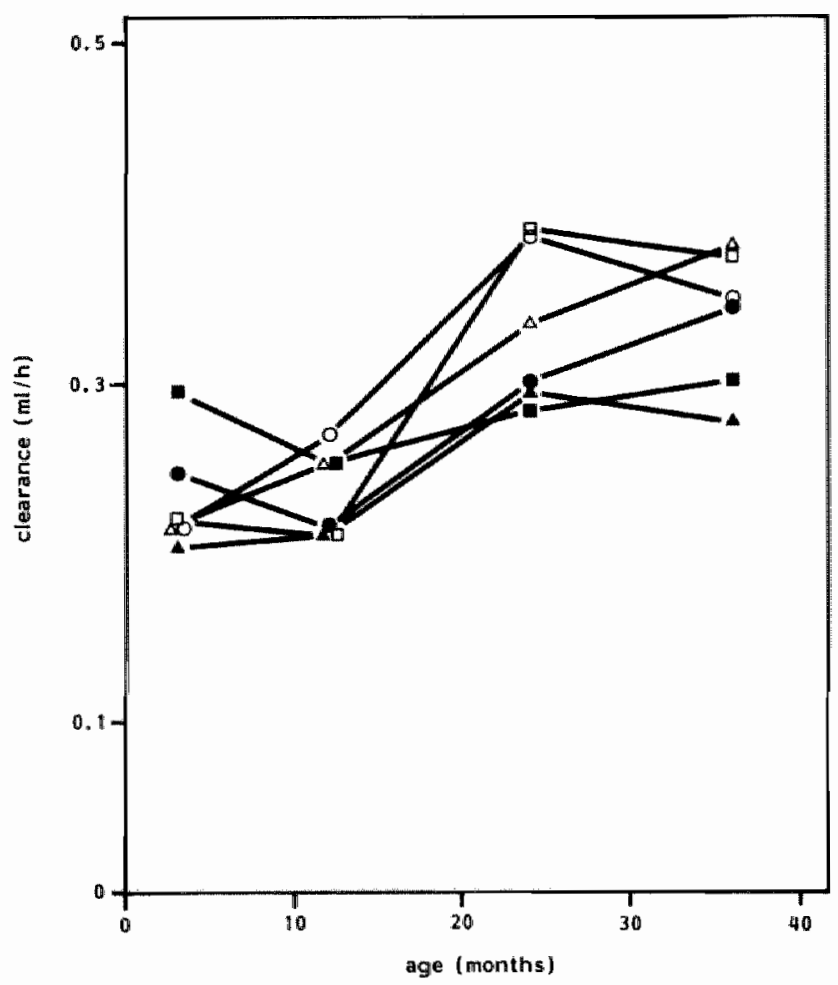

Fig. VI-2. Age-related changes in clearance walues of albumin isolated from 3-manth-old rats in the six survivor rats (aged 36 months).

(E) ratmumber $1-1$, (O) ratnumber $\|-3,(\Delta)$ ratnumber $1 \|-1$, ( 0 ) ratnumber Vil-0, ( 0 ) ratnumber $V 11-2,(\Delta)$ ratnumber vill-o. 


\section{- Albumin clearance}

Clearance values were calculated from plasma radioactivity curves after injection of albumin isolated from 3 -month-old rats as well as after injection of albumin isolated from rats of the same age as the recipient. Age-related changes in this characteristic are shown in Table VI-3. After injection of 3-month-old albumin, an increase in the

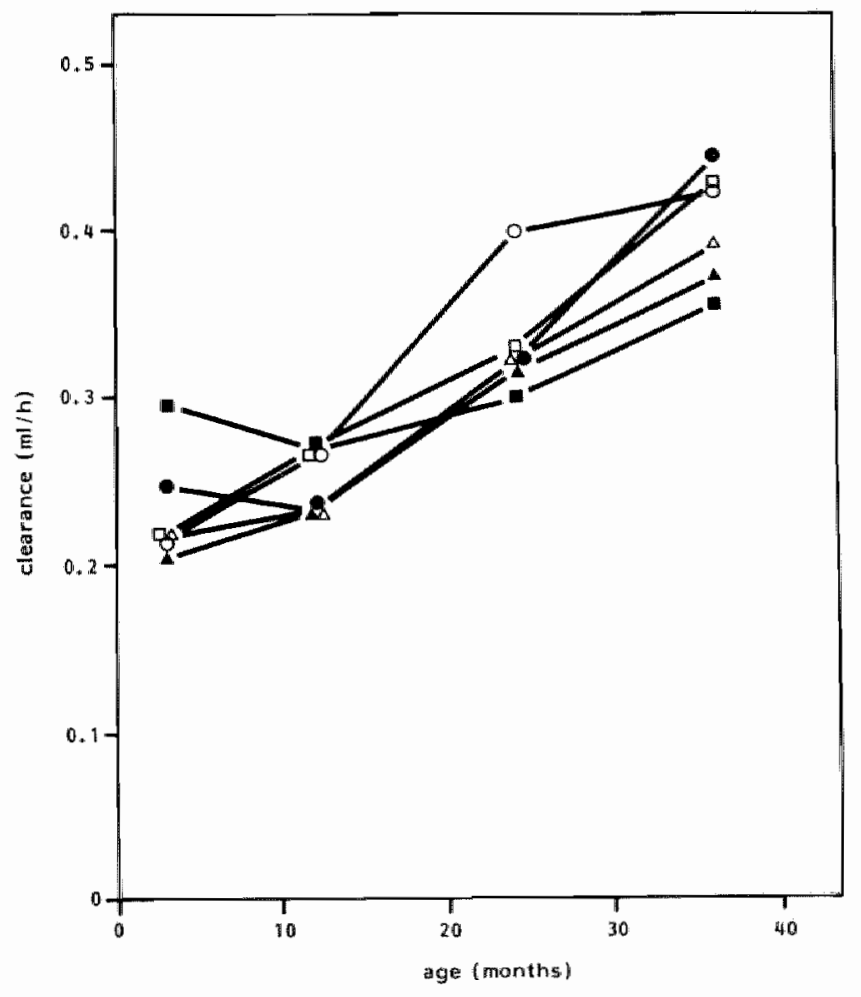

Fin. Wi-3. Age-related changes in clearance values of age-matched albumin in the sik surwivar rats (aged 36 manths).

(E) ratnumber $1-1,(0)$ ratnumber $1-3,(\Delta)$ ratmumber $11-4,(0)$ ratrumber

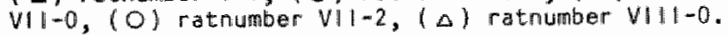




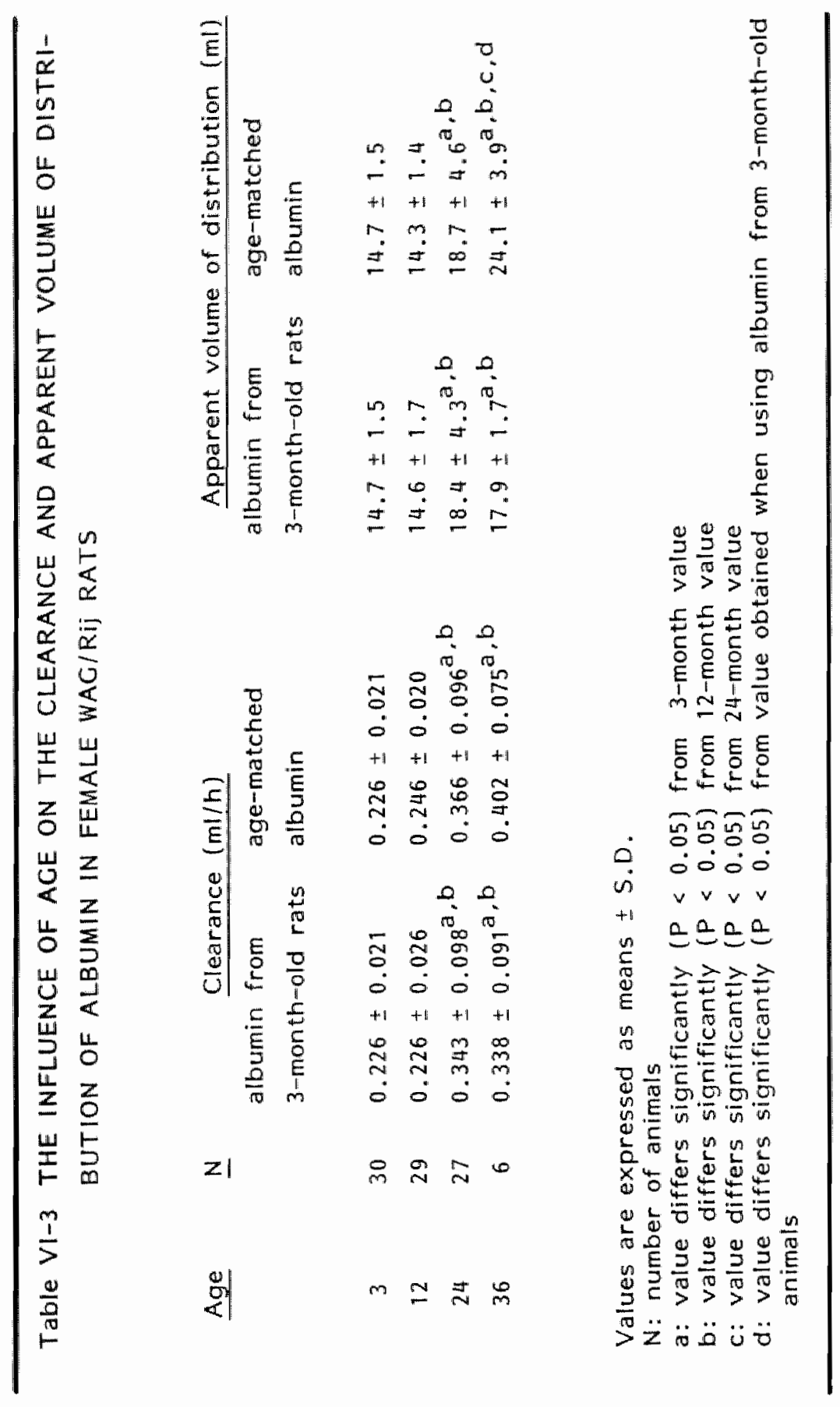


clearance values at between 12 and 24 months of age was observed. All rats showed this increase. After 24 months of age no significant change in the clearance was observed. For the six 36 -month-old survivors, the influence of age on the clearance is depicted individually in Fig. VI-2.

The clearance values obtained after injection of albumin isolated from rats of the same age as the recipients are also shown in Table VI-3. The values for the six survivor rats are depicted in Fig. VI-3. The values are higher at 24 and 36 months of age than those at 3 and 12 months of age. In contrast with the results obtained using albumin isolated from 3-month-old rats, higher values were obtained at 36 months of age compared with those obtained at 24 months of age when animals were injected with albumin from an age-matched donor. The increase in clearance of age-matched albumin between 12 and 36 months of age was found in all rats. At 36 months of age, a clear difference is observed between the clearance of age-matched albumin and of albumin isolated from 3 -month-old rats.

- Apparent volume of distribution of albumin

Age-related changes in the apparent volume of distribution are also dependent on the age of the albumin donor rats. In 36-month-old rats the apparent volume of distribution of age-matched albumin is significantly higher than that of albumin isolated from 3-month-old rats. Independent of the origin of administered albumin, all individual animals showed an increase in this characteristic between 12 and 24 months of age (Table VI-3; Fig. VI-4; Fig. VI-5). The only exception is rat $1-1$, whose volume of distribution remained constant. Between 24 and 36 months of age, a further increase was only seen with the agematched albumin (Table VI-3, Fig. VI-4; Fig. VI-5).

- Plasma albumin and protein concentrations

Plasma albumin and protein concentrations are shown in Table VI-4. It can be seen that aging does not exert any influence on these values with albumin accounting for about $45 \%$ of the total plasma proteins in 


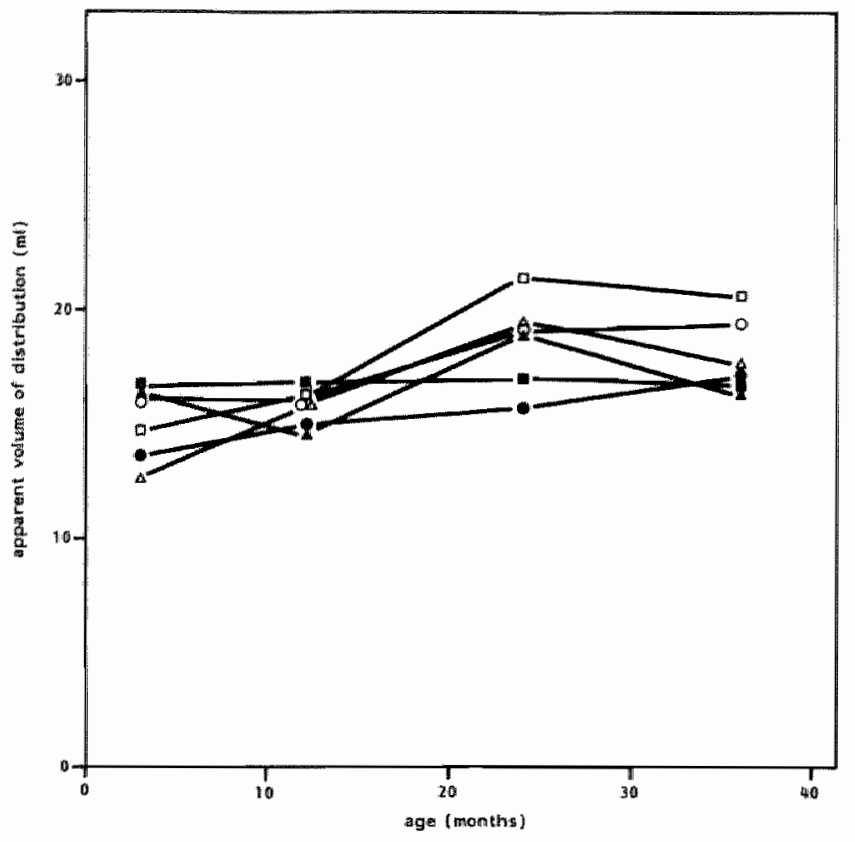

Fig. Vi-4. Age-related changes in apparent volume of distribution of albumin isolated fram 3-manth-old rats in the six survivor rats (aged 36 months).

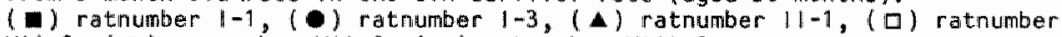
WI $-0,(0)$ ratnumber $V I 1-2,(\Delta)$ ratnumber vill -0 .

all age-groups.

- Absolute albumin elimination rate and whole-body albumin pool

The absolute albumin elimination rate and wholle-body albumin pool were calculated as described in Chapter 11. These calculations were only carried out on data obtained with age-matched albumin. The results are shown in Tablle V/-5. The individual values for the six survivor rats are depicted in Figs. VI-6 and VI-7. Both characteristics show a uniform increase at between 12 and 36 months of age, with the exception of rat $1-1$ whose elimination rate showed a slight increase only after 24 months of age and whose whole-body albumin pool re- 


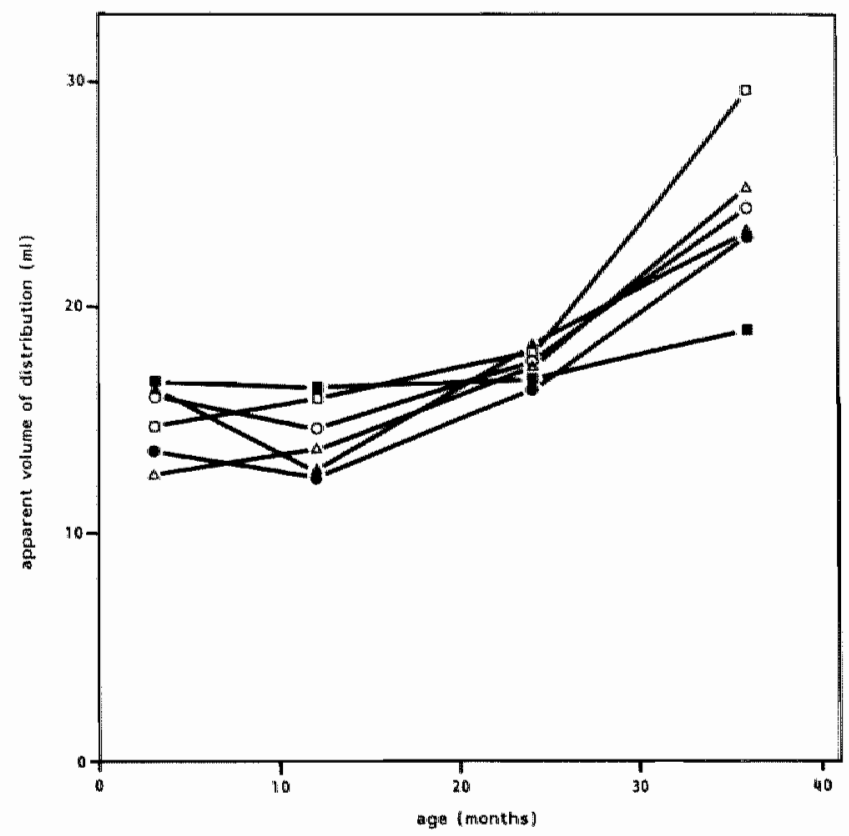

Fig. VI-5. Age-related changes in apparent volume of distribution of age-matched allbumin in the six survivor rats (aged 36 months).

(E) ratnumber $1-1$, (O) ratnumber $1-3$, (A) ratnumber $11-1$, ( VI1 $-0,(0)$ ratnumber $v i l-2,(\Delta)$ ratnumber vill-0.

mained constant up to 36 months of age.

- Albumin and protein excretion via the urine

The urinary excretion of albumin and total protein increases with age up to 30 months of age $($ Table $\mathrm{V} I-6)$. Between 30 and 36 months of age only 3 out of the 6 survivors show an increase in both albumin and total protein excretion (Figs. $V(-8$ and $V(1-9)$. Furthermore, it can be seen that changes in urinary albumin excretion always reflect an equivalent change in total protein excretion. There appears to be an enormous heterogeneity in the age at which the increase in urinary albumin and protein loss starts. Some rats show this increase at 
Table VI-4 THE INFLUENCE OF AGE ON PLASMA ALBUMIN AND TO-

TAL PROTEIN CONCENTRATION IN FEMALE WAG/RIj RATS

$\begin{array}{ccccc}\begin{array}{c}\text { Age } \\ \text { (months) }\end{array} & N & \begin{array}{c}\text { plasma } \\ \text { albumin } \\ (\mathrm{mg} / \mathrm{ml})\end{array} & \begin{array}{c}\text { plasma } \\ \text { protein } \\ (\mathrm{mg} / \mathrm{ml})\end{array} & \begin{array}{c}\text { percentage albumin } \\ \text { of total protein }\end{array} \\ & 30 & 33.6 \pm 3.3 & 66.1 \pm 5.1 & 50.9 \pm 4.3 \\ 3 & 29 & 31.8 \pm 1.6 & 76.6 \pm 10.2 & 42.2 \pm 5.8 . \\ 12 & 27 & 31.3 \pm 6.0 & 76.3 \pm 5.9 & 42.5 \pm 3.1 \\ 24 & 12 & 32.1 \pm 4.6 & 66.3 \pm 8.4 & 47.0 \pm 6.7 \\ 30 & 6 & 33.2 \pm 2.5 & 71.3 \pm 5.9 & 47.0 \pm 6.7 \\ 36 & & & \end{array}$

Values are expressed as means \pm S.D. $N$ : the number of animals

Table VI-5 THE INFLUENCE OF AGE ON THE ABSOLUTE ALBUMIN ELIMINATION RATE AND THE WHOLE-BODY ALBUMIN POOL IN FEMALE WAGIRIj RATS

$\begin{array}{cccc}\begin{array}{c}\text { Age } \\ \text { (months) }\end{array} & N & \begin{array}{c}\text { Absolute elimination } \\ \text { rate }(\mathrm{mg} / 24 \mathrm{~h})\end{array} & \begin{array}{c}\text { Whole-body albumin } \\ \text { pool (mg) }\end{array} \\ 3 & 30 & 184 \pm 26 & 493 \pm 61 \\ 12 & 29 & 187 \pm 18 & 454 \pm 53 \\ 24 & 27 & 278 \pm 79^{\mathrm{a}, \mathrm{b}} & 620 \pm 170^{\mathrm{a}, \mathrm{b}} \\ 36 & 6 & 323 \pm 49^{\mathrm{a}} \mathrm{b}, \mathrm{c} & 810 \pm 140^{\mathrm{a}, \mathrm{b}, \mathrm{c}}\end{array}$

Values are expressed as means $\pm S . D$.

$N$ : the number of animals

a: value differs significantly $(P<0.05)$ from 3 -month value

$b$ : value differs significantly $(P<0.05)$ from 12 -month value

c: value differs significantly $(P<0.05)$ from 24 -month value 
between 12 and 24 months of age, others after 24 months of age. One of the animals (rat VII-3), that died at 31 months of age, did not show such an increase at all.

In all cases, after the start of the increase in protein excretion via the urine, albumin becomes an increasingly more important constituent of the excreted protein (Fig. $V \mid-10$; Table $V \mid-6$ ). In 3-month-old ani-

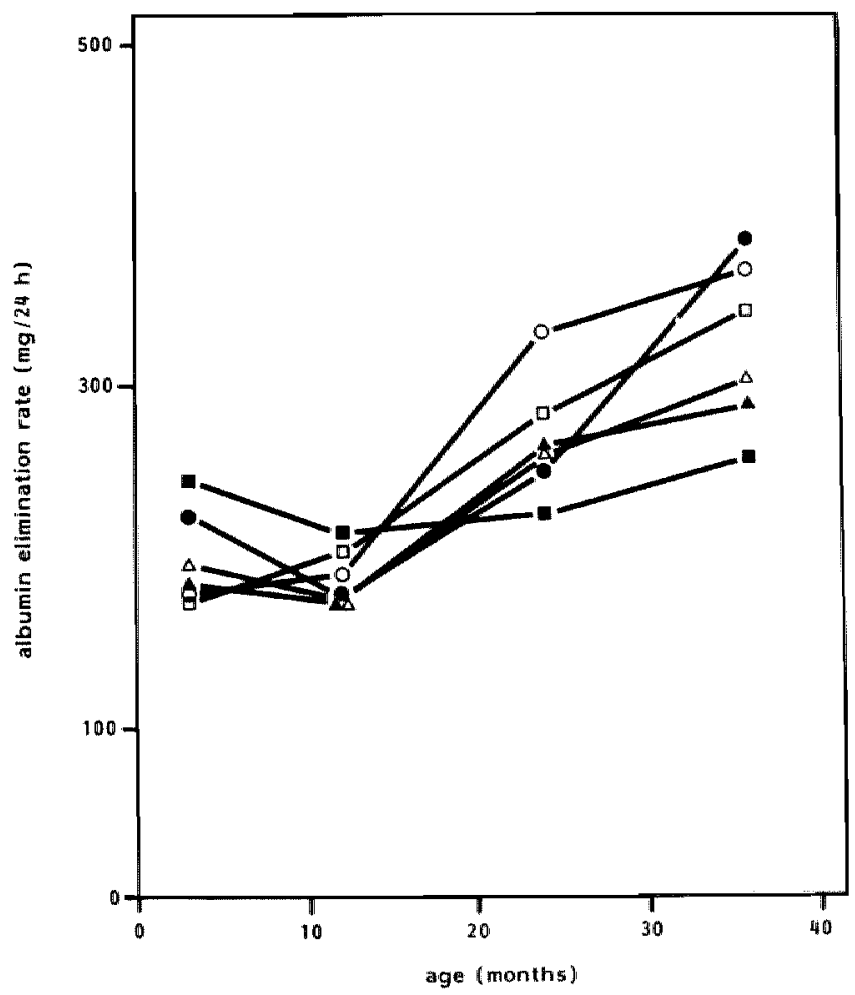

Fig. W-6. Agle-related changes in absolute albumin elimination rate in the six survivar rats (aged 36 months).

(Q) ratnumber $1-1$, (O) ratnumber $1-3$, (A) ratinumber $11-1$, (口) ratinumber VII $-0,(0)$ ratnumber $v i l-2,(\Delta)$ iratinumber vill-0. 
malls only $4.5 \%$ of the excreted protein is albumin-like. At 36 months of age this value has increased to 41\%, which is similar to the proportion of plasma proteins that are "albumin-like" ".

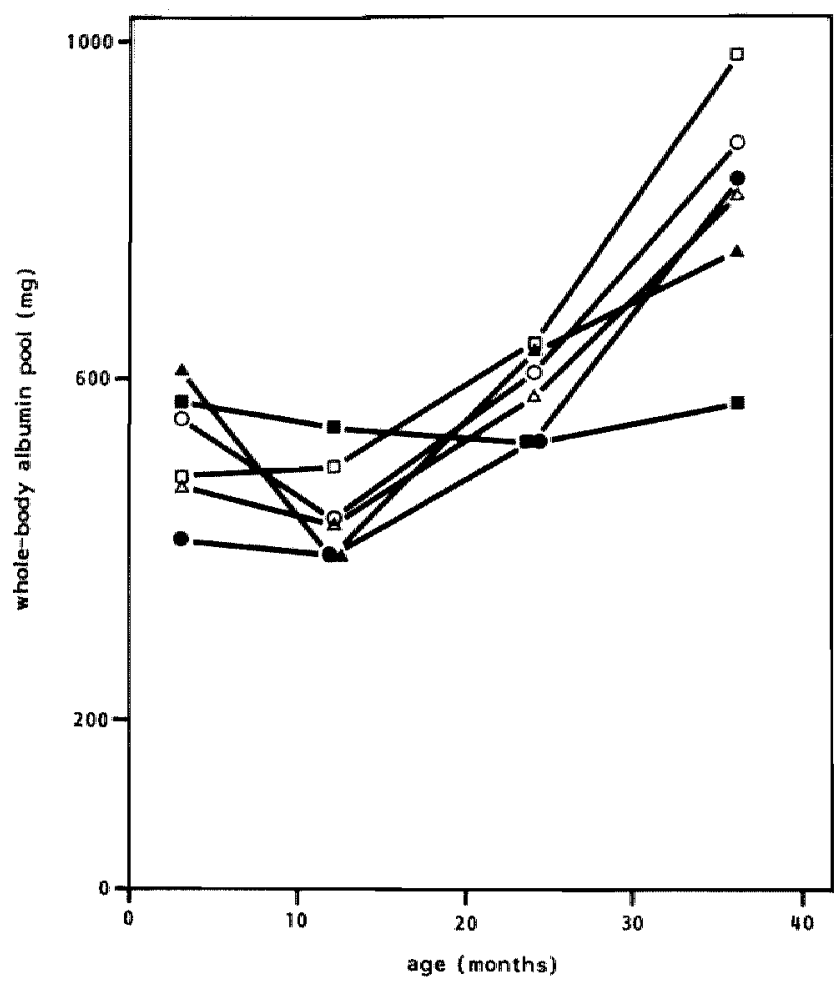

Fig. VI-7. Age-related chenges in the whole-body albumin pool in the six survivor rats (aged 36 months).

(I) ratnumber 1-1, (O) ratnumber 1-3, (4) ratnumber $11-1,(0)$ ratnumber VII-0, (0) ratnumber $V(1-2,(\Delta)$ ratnumber $v \| 11-0$.

VI-3c. Total liver RNA content and albumin mRNA content

The content of total RNA and albumin mRNA in the liver was determined in the six survivor rats at 36 months of age. The results are shown in Table $\mathrm{VI}-7$. It can be seen that the values reported there 
compare favourably with thase obtained for the 36-month-old rats reported in Chapter IV.

In Fig. VI-11, the amount of albumin mRNA in the livers of the six survivor rats is expressed as a function of the levels of absolute albumin elimination. It is clear that no clear cut linear relationship exists between these two characteristics.

Table VI-6 THE INFLUENCE OF AGE ON URINARY EXCRETION OF TOTAL PROTEIN AND ALBUMIN IN FEMALE WAG/RII RATS

Age $N$ protein excretion albumin excretion percentage (months)

albumin of

excreted

$(\mathrm{mg} / 24 \mathrm{~h})$

$(\mathrm{mg} / 24 \mathrm{~h})$

protein (8)

$0.12 \pm 0.04$

$4.5 \pm 2.0$

$12 \quad 292.4 \pm 0.9$

$0.21 \pm 0.13$

$9.5 \pm 4.9$

24

$276.0 \pm 3.9^{a, b}$

$1.3 \pm 1.6^{a, b}$

30

$1230 \pm 16^{a, b, c}$

$10.9 \pm 7.8^{a, b, c}$

$15.7 \pm 9.9^{a} \cdot b$

$19.5 \pm 5.1^{a, b}, c$

36

$648 \pm 14^{a, b, c}$

$31 \pm 12^{a, b}, c$

$40.9 \pm 4.1^{a, b}, c$

Values are expressed as mean \pm S.D.

$N$ : the number of animals

a: value differs significantly $(P<0.05)$ from 3 -month value

$b$ : value differs significantly $(\mathbb{P}<0.05)$ from 12 month value

c: value differs significantly $(P<0.05)$ from 24 -month value

VI-3d. Histological data

A wide variety of pathological lesions were observed in this study. The most frequenly observed lesions included: pituitary tumors Imedul- 
lary thyroid carcinomas, biliary cysts and foci of cellular alteration in the liver, mammary tumors, and ovarian cysts (Table VI-8). These lesions are usual accompaniments of aging in this rat strain (Burek, 1978). Protein-losing enteropathy and severe hemorrhage were not observed in this study. Ceneralized neoplasia, which could influence protein turnover, was observed in three cases: IV-1, myeloid leukemia; V-3, myeloid leukemia, and; VI-2, metastatic osteosarcoma. However, cases $\mathrm{V}-3$ and $\mathrm{VI}-2$ were not included in the statistical correlation analysis due to the long interval between the last urinary protein determination and death. Histologic evidence of increased protein synthesis (focal areas of hepatocellular basophilia) in the liver was only observed in one animal $(\mathrm{V} \| \mathrm{II}-0)$. However, the light microscope is a relatively insensitive device for this purpose.

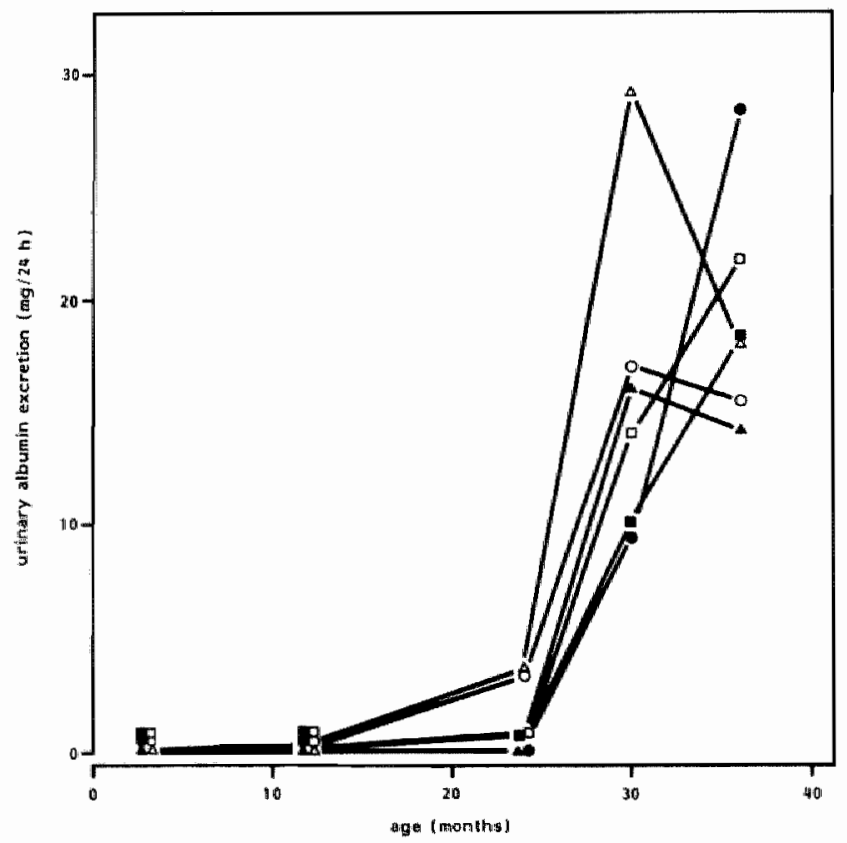

Fig. V1-8. Age-related changes in the urinary albumin excretion in the six survivor rats (aged 3.6 months).

(a) ratnumber $1-1$, ( - ) ratnumber $1-3$, ( $\Delta$ ) ratnumber $1 \mid-1$, (D) ratnumber vil -0, (o) ratnumber $v i l-2,(\Delta)$ ratnumber villi-0. 
Table VI-7 TOTAL LIVER RNA CONTENT AND ALBUMIN mRNA LEVELS IN THE SIX 36-MONTH-OLD SURVIVOR RATS

\begin{tabular}{cccc} 
Ratnumber & $\begin{array}{c}\text { liver weight } \\
(\mathrm{g})\end{array}$ & $\begin{array}{c}\text { RNA content } \\
\text { (mg/g of liver) }\end{array}$ & $\begin{array}{r}\text { albumin mRNA } \\
\text { content ( } \mu \mathrm{g})\end{array}$ \\
$1-1$ & 6.11 & 6.41 & 156.4 \\
$1-3$ & 7.01 & 7.24 & 173.4 \\
$\mid 1-0$ & 7.30 & 5.43 & 130.5 \\
VII-0 & 6.33 & 6.55 & 136.0 \\
VII-2 & 7.32 & 6.80 & 182.9 \\
VIII-0 & 5.44 & 6.45 & 137.2 \\
means \pm S.D. & $6.58 \pm 0.75$ & $6.48 \pm 0.60$ & $153 \pm 22$ \\
\hline
\end{tabular}

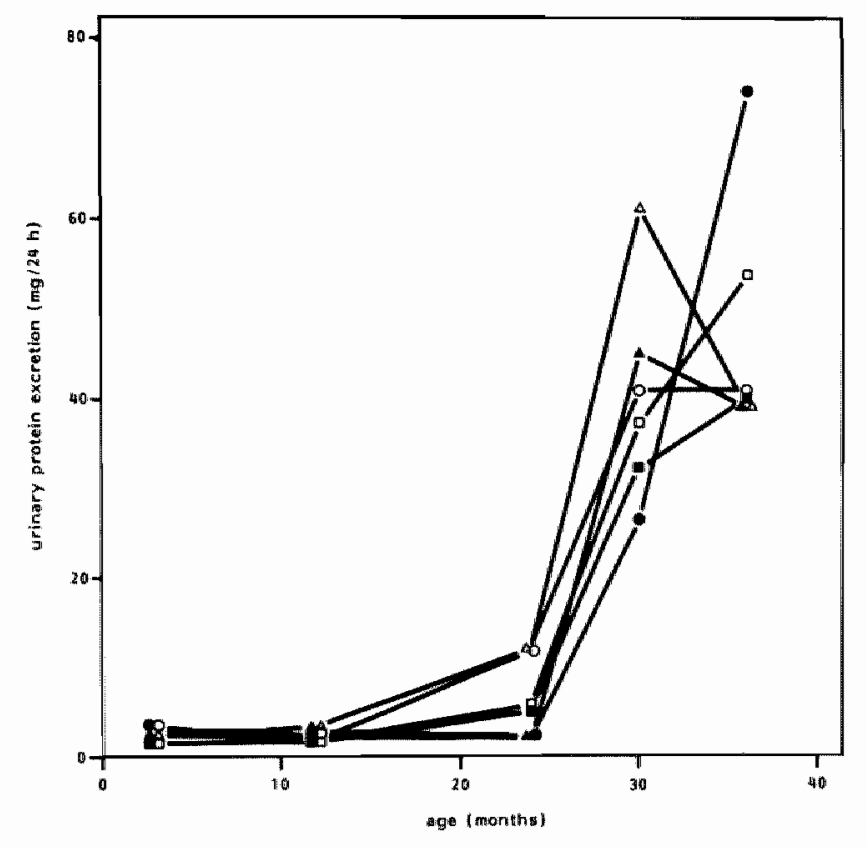

Fig. Vi-9. Age-related changes in the urinary protein excretion in the stix survivor rats (aged 36 months).

(D) ratnumber $1-1$, (O) ratnumber $1-3$, (4) ratnumber $11-1$, (口) ratnumber VI $-0,(0)$ ratimumber $V \| 1-2,(\Delta)$ ratnumber $W 111-0$. 
The renal lesions that were observed were predominantly related to chronic progressive nephrosis (CPN), which is a common disease of laboratory rats. The basic lesions of this disease are: glomerular changes of thickened Bowman's capsule and mesangium, cast formation and atrophic proximal tubule with thickened basement membrane (Cray et al., 1982). The grading scale for these renal lesions was based on

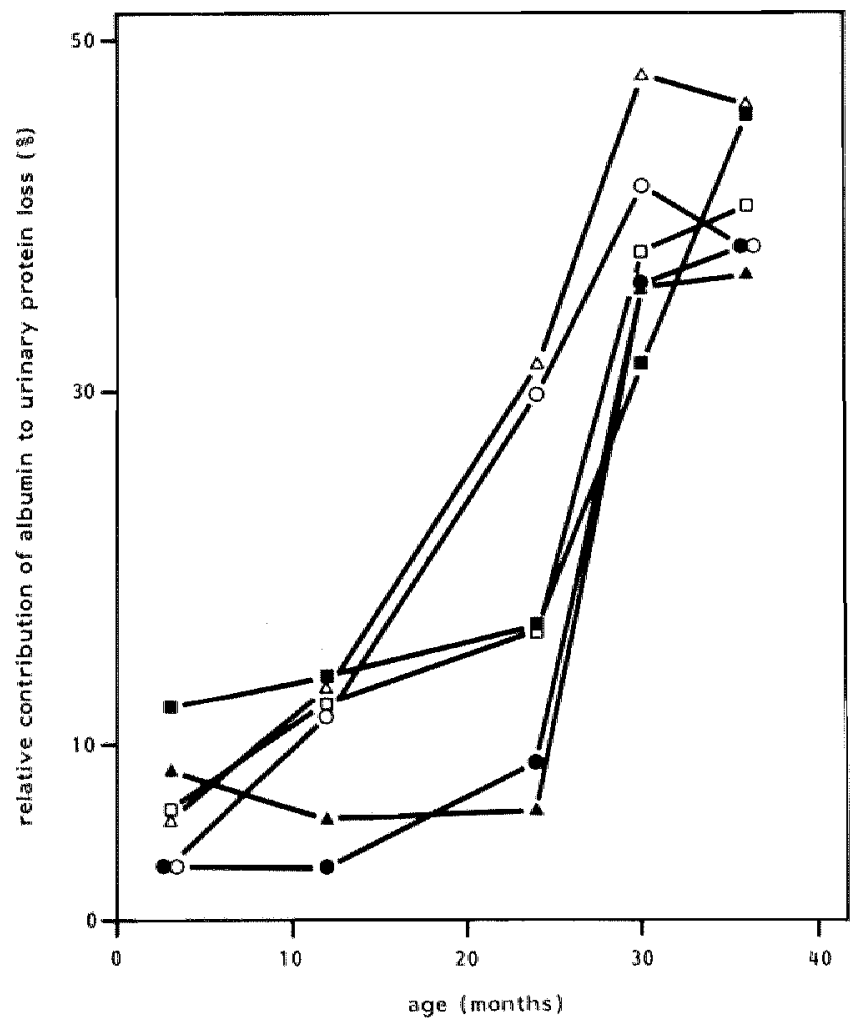

Fig. VI-10. Age-related changes in the relative contribution of albumin to protein loss via the urime in the six survivor rats (aged 36 months).

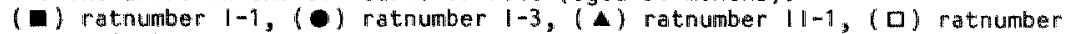

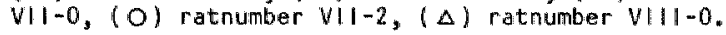


the severity of the individual basic lesions and on the number of nephrons affected as described by Gray et al. (1982): Grade 0, normal or minimal lesions: Grade 1, mild lesions; Grade 2, moderate lesions, and; Grade 3, marked lesions. All grades of histologic severity, except for Grade 3, were observed in the kidneys (Figs. VI-12a-d).

There was a significant correlation between the histologic score of renal lesions and the total amount of urinary protein $(r=0.8613$; $P<$ $0.001)$ and urinary albumin $(r=0.9029 ; P<0.001)$ (Table V'l-9; Table $\mathrm{V}(-10)$.

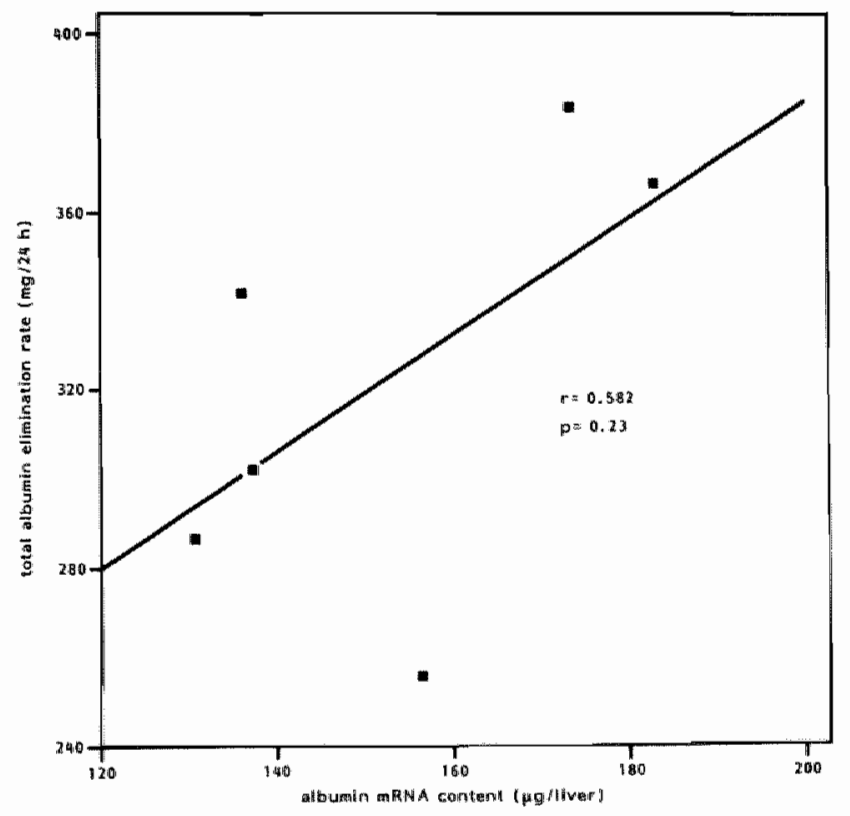

Fig. VI-11. The relationship between the absolute rate of albumin elfimination and the albumin mRNA content in the six survivor rats (aged 36 months). 
The work reported in this chapter involves a longitudinal study of the influence of age on albumin elimination. The experimental set up was the same as in the previously performed cross-sectional study [Chapters II and III]. After injection of albumin isolated from 3month-old rats into other rats at several time-points during their life, it was observed that aging was associated with changes in both clearance and apparent volume of distribution. All animals showed higher levels for these two characteristics at 24 months of age than they did at 3 or 12 months of age (Table VI-3; Figs. VI-2 and VI-4). No significant changes occurred between 3 and 12 months of age or between 24 and 36 months of age. These results are silmilar to those reported in Chapter $\| 1$. The elimination half-life appeared to decrease significantly between 12 and 24 months of age (Table VI-2) and this was not observed in the cross-sectional study, probably because of the small number of animals used in that study.

Between the ages of 3 and 24 months the age of the animal from which the albumin was obtained had no effect on the changes in clearance and the apparent volume of distribution. However, after the age of 24 months, the age of the albumin donor influenced the values for clearance and apparent volume of distribution in a different manner. A significant increase could be observed in these two characteristics between the ages of 24 and 36 months after the injection of age-matched albumin (Table VI-3; Figs. $V \mid-3$ and $V \mid-5$ ). From Table VI-2 it can be seen that after injection of age-matched albumin, only the value for elimination half-life in 24-month-old rats is lower than that in 3-month-old ones.

Table VI-4 shows the influence of age on the plasma albumin and protein concentration. During the life-span of the animals studied, no significant changes in these parameters occurred. Some variation with age was seen, but this variation is smaller than the inter-individual variation. In all age-groups, albumin comprises about $45 \%$ of the total plasma protein pool. Since the plasma albumin concentration remains 
constant with age, the age-related changes in clearance and apparent volume of distribution observed after injection of age-matched albumin are reflected in the absolute albumin elimination rate and whole-body albumin pool, respectively. Therefore, the observed age-related increase in clearance and apparent volume of distribution after injection of age-matched albumin also holds for these characteristics.

As described in Chapter III, urinary excretion of proteins and albumin increases with age in several rat strains (Beauchene et al." 1970; Obenrader et al., 1974a; Alt et al., 1980). Such a change is also seen in the femalle WAG/Ri] rat, the rat strain used in our studies (Chapter 111 ). In the longitudinal study presented here, protein and albumin excretion in the urine was also determined. It was shown (Table VI-6) that both excretion processes increased with age in female WAG/Rij rats up to 30 months of age. After 30 months of age some variation was seen in these changes (Figs. VI-8 \& VI-9). In some rats these excretion rates increased, while in others a decrease was observed.

One phenomenon which occurred in all animals was a proportionall increase in the contribution of albumin to the urinary protein excretion. In 3-month-old rats only 4.58 of total urinary protein was albumin and this had increased to 418 by 36 months of age. Since this percentage approaches the values found in plasma, it probably represents non-selective protein leakage into the urine in old rats. The age of onset of this increased contribution of albumin was more variable (Fig. VI-10). Some rats already showed high percentages at 12 months of age.

Aging rats display a wide variety of pathological lesions some of which are strain specific (Burek, 1978). In this study an attempt was made to correlate the data on albumin elimination and urinary protein loss with the occurrence of such lesions. The only clear cut correlation that could be observed was between urinary protein and albumin loss and the presence and severity of the renal lesions. One complicating factor in this study is the time interval between the last determination on urinary protein loss and the time of death. If this time span was 
Table VI-8 PATHOLOGICAL LESIONS OBSERVED IN FEMALE WAG/Rij RATS USED IN THIS STUDY

Organs Lesions

Liver

Thyroid

medullary thyroid carcinoma

parathyroid hyperplasia

Foci of cellular alteration

biliary cysts

hepatocellular necrosis

angiectasis

macrophage aggregation in

sinusoids.

myeloid leukemia

sponglosis hepatis

metastatic osteosarcoma

hepatocellular atrophy

granulamatous inflammation

nodular hyperplasia

$$
\text { parathyroid hyperplasia }
$$

Pituitary gland

pituitary adenoma

pituitary carcinoma

pars intermedia cysts

multiple cysts

chronic progressive

nephrosis

tubular abcess

nephroblastoma
Number Mean age (range) in months

$1731(24-36)$

$334(31-36)$

$3 \quad 33(30-34)$

$231(30-32)$

$232(30-34)$

$2 \quad 29.5 \quad(27-32)$

$230 \quad(30)$

131

125

135

135

$1931(24-36)$

$331(27-36)$

$2132(24-36)$

124

136

$7 \quad 32(24-36)$

$2131(24-36)$

1. 32

1. 25 
Heart

moderate myocardial fibrosis

congestive cardiomyopathy

$36 \quad 36)$

focal thrombus

islet cell carcinoma

pancreatic duct ectasia

$32.5(29-36)$

$231(30-32)$

Thymus

mixed thymoma

2

$32.5(29-36)$

thymic hyperplasia

130

Uterus

cystic glands

endometrial polyp

endometritis

unilateral hydrometra

$\begin{array}{lll}2 & 36 & (36) \\ 2 & 36 & (36)\end{array}$

fibroma

stromal cell sarcoma

myeloid leukemia

hemorrhage

2

1

Mammae

fibroadenoma

$4 \quad 34(30-36)$

tubulopapillary carcinoma

$3 \quad 34(31-36)$

fibroma

126

adenocarcinoma

124

lobular hyperplasia with focal

atypia

136

Lymph modes

capillary hemangioma

$1 \quad 34$

myeloid leukemia

127

Adrenal gland

cortical adenomia

136

Stomach

severe ulcerative gastritis

Oral cavity

squamous cell carcinoma

1

33

Nasal cavity

focal suppurative rhinitis 
Table VI-9 LAST DETERMINATION OF URINARY ALBUMIN AND PROTEIN EXCRETION IN THE RATS BEFORE THEIR DEATH AND THE HISTOLOGICAL SCORE OF RENAL LESIONS

\begin{tabular}{|c|c|c|c|}
\hline Ratnumber & $\begin{array}{c}\text { Urinary protein } \\
\text { (mg/24 h) }\end{array}$ & $\begin{array}{c}\text { Urinary albumin } \\
\qquad(\mathrm{mg} / 24 \mathrm{~h})\end{array}$ & $\begin{array}{c}\text { histological } \\
\text { score }\end{array}$ \\
\hline $1-0$ & 2.8 & 0.20 & * \\
\hline$I-1$ & 40 & 18 & 2 \\
\hline $1-2$ & 6.5 & 0.75 & 0 \\
\hline $1-3$ & 74 & 28 & 2 \\
\hline $\mid \|-0$ & 2.8 & 0.23 & * \\
\hline\|\|$-1$ & 39 & 14 & 2 \\
\hline\|\|$-2$ & 2.8 & 0.20 & * \\
\hline $11-3$ & 2.7 & 0.45 & 0 \\
\hline$|I|-0$ & 30 & 11 & 1 \\
\hline|| $\mid-1$ & 29 & 8.8 & 1 \\
\hline\|\|$-2$ & 8.5 & 1.0 & * \\
\hline\|\| $\mid-3$ & 20 & 4.5 & 1 \\
\hline$\| V-0$ & 9.4 & 3.3 & * \\
\hline IV-1 & 8.2 & 1.1 & 0 \\
\hline $1 \mathrm{~V}-2$ & 8.8 & 1.5 & 1 \\
\hline IV -3 & 21 & 8.4 & 1 \\
\hline$V-0$ & 4.2 & 0.68 & 0 \\
\hline$V-1$ & 6.3 & 1.9 & * \\
\hline$V-2$ & 19 & 7.8 & 2 \\
\hline$V-3$ & 2.4 & 0.23 & * \\
\hline $\mathrm{VI}-0$ & 4.9 & 0.47 & $\star$ \\
\hline$V I-1$ & 3.5 & 0.16 & $\star$ \\
\hline$V \|-2$ & 5.6 & 1.6 & * \\
\hline $\mathrm{V} /-3$ & 3.5 & 0.26 & * \\
\hline
\end{tabular}


$\mathrm{V} \| 1-0$

VII-1

VII-2

VII-3

VIII-0

VIII-1
54

7.9

41

4.4

39

3.4
21

0.48

16

0.16

18

0.33
2

0

2

*

2

0

* = animal was not included in the histological scoring because the time interval between the last protein determination and renal fixation was greater than 16 weeks

more than 16 weeks, histological scoring was not included since during this period major changes in the animals' pathology could have occurred. The age-related increase in the relative contribution of albumin to total urinary protein excretion can probably be explained by the increased permeability of the glomerulus to larger proteins as described by Alt et al. (1980).

TABLE VI-10 THE MEAN AMOUNT OF URINARY ALBUMIN AND PROTEIN EXCRETION IN RELATION TO THE HISTOLOGICAL SCORE OF RENAL LESIONS

Histological

score

$\begin{array}{llllll}0 & 6 & 5.5 & (2.7-8.2) & 0.64 & (0.33-1.1) \\ 1 & 5 & 22 & (8.7-30) & 6.9 & (1.5-11) \\ 2 & 7 & 44 & (20-74) & 18 & (7.8-28)\end{array}$

$N$ : the number of animals 
In Chapter IV, evidence was presented that an increased albumin elimination with age was accompanied by increased albumin mRNA vels. At the end of the longitudinal study, levels of albumin mRNA were determined in the six 36-month-old survivor rats in order to compare these values with the albumin elimination rate. Although both factors are high in comparison to values found in young rats, no linear relationship was observed between the magnitude of the albumin elimination rate and the albumin mRNA levels (Fig. VI-11). It remains to be established whether this lack of correlation relates to the number of animals being to small, or to any rellationship being rather complex.

In summary, the elimination rate of serum albumin is dependent upon the age of the animall. The increase in this elimination rate was shown to be the result of a change in the animals' physiology (between 12 and 24 months of age) and to a change in the albumin molecule (between 24 and 36 months of age). Since this increase could be abserved in all animals, it can be concluded that albumin elimination is under a real age-related control and that the observed changes are not due to cohort effects. Furthermore, a direct correlation was seen between the

Fig. W-12. a) Grade 0 (normal): There are no morphologic alterations (hematoxyline-phloxine-saffron, HPS, 20101 .

b) Crade 1 (mild): There is focal, segmental thickening of Bowman s capsule (arrows) and atrophy of the glomerular tuft (asterisk). Tubules (T) are lined by mildiy attenuated epithelial cells with moderately thickened basement membranes (HPS, $\times 210)$.

c) Crade 2 (moderate): There is marked segmental sclerosis of the glomeruilus with thickeried basement membranes. and adhesions to Bowman's capsule (arrows). Several tubules (T) are atrophled, in ined by markedly attenuated to iryperplastic epithelial cells with pronounced thickening of the basement membrame. other tubules (asterisk) are irregularly dilated, contain proteinaceous materi. 1 , and are lined by hypertrophied epithelial cells. The interstitium contains a focal ggregate of 1 ymphocytes. (HPS, $\times 210$ ).

d) Special stains demonstrate comparative thickening of basenent membrane between normal (upper photograph) and affected animal (lower photographin) (PASMAzan, $\times 210)$. 

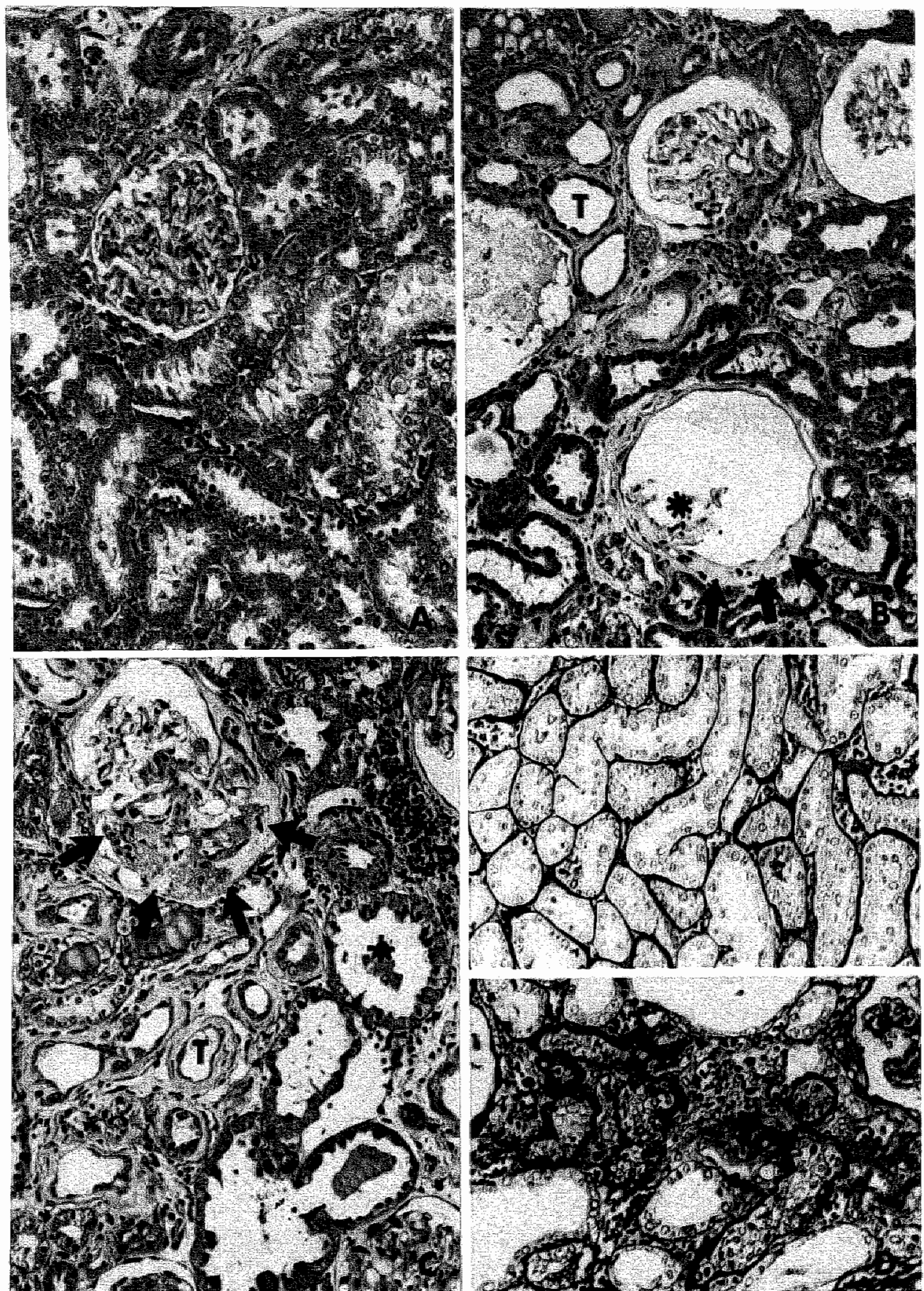

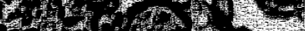
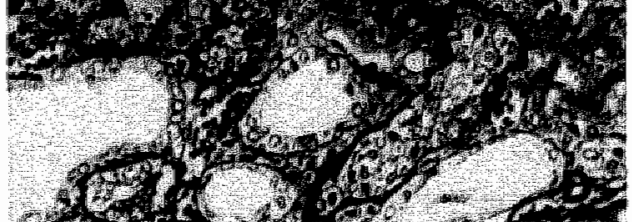
occurrence of kidney lestons and urinary excretion of total protein and albumin. No correlation was observed between the rate of albumin ellmination and the levels of albumin $m R N A$ in individual rats. 


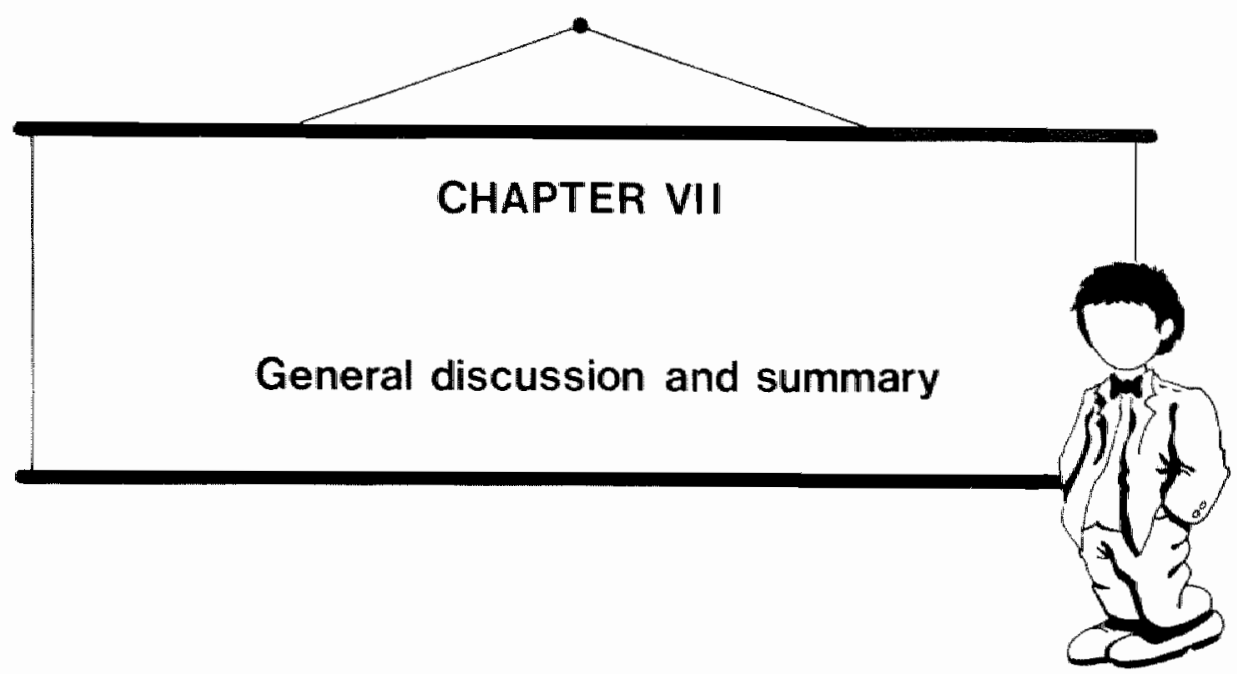

Aging is a complex phenomenon, the nature and origin of which are presently unknown. Many theories have been proposed to explain this process. Among these theories, several exist that invoke a role for proteins; their synthesis and their elimination. Many studies have been performed on protein metabolism and aging (Richardson, 1981; Richardson $\varepsilon$ Birchenall-Sparks, 1983; Makrides, 1983). However, most of these studies have concentrated on overall protein metabolism and changes in those factors that might influence overall protein metabolism. It is unlikely that changes in individual protein metabolism would only be under some uniform, age-related control. It would therefore be of considerable interest to study the influence of age on the metabolism of one specific protein.

In this study, rat serum albumin was chosen. This is because several previous reports have shown that the synthesis of this protein was under an age-related control in rats (Beauchene et al.. 1970; Salatka et al., 1971; Ove et al., 1972: Van Bezooijen et al. 1976; Van Be- 
zooijen or Kook, 1977). Little information on the underlying mechanisms behind this age-related change in albumin symthesis and on the influence of age on albumin elimination was available. The aim of the studies described in this thesis was to gain insight into the influence of age on the elimination of albumin, into the albumin excretion processes responsible for such putative changes, and into the molecular basis of the age-related changes in albumin synthesis. To this end, these aspects were systematically investigated in female WAG/Rij rats.

\section{VII-1. ALBUMIN ELIMINATION AND AGING}

Albumin elimination rates were determined in rats of various ages in both of two different ways. In the first, clearance studies were performed after injection of albumin isolated from 3-month-old rats so that any age-related changes would be onlly due to changes in the animals' physiolagy. In the second, clearance studies were performed using albumin isolated from rats of the same age as the recipients. In this way. possible changes could be attributed to both changes in the animals' physiology and age-related changes in the albumin molecule. It was found that albumin elimination increased between 12 and 36 months of age. Since the increase in albumin elimination up to 24 months of age was independent of the age of the albumin-donor rat, it could be concluded that this increase was due to an age-related change in the physiology of the recipients. The increase in albumin elimination between 24 and 36 months of age was only observed after injection of age-matched albumin and could therefore be attributed to a changed albumin molecule combined with an altered physiology of the rat since albumin isolated from 36-month-ald rats was handled in 3-month-old ones in the same way as age-matched albumin. Concomitant with the increased albumin elimination rate, an increase in the whole-body albumin pool was observed. The results obtained in the longitudinal study (Chapter VI) showed that the contribution of a possibly altered albumin molecule to the age-related changes in albumin elimination occurs in every individual rat as well as the increase in albumin elimi- 
nation rate and whole-body albumin pool. Only one exception was observed, and this rat did not show an increase in whole-body albumin pool with age.

The indications that were obtained with regard to age-related changes in the rats physiology and in the albumin molecule were indirect. Therefore, no firm statements can be made as to the nature of these changes. However, literature data showed that an increased permeation of the vasculature for albumin might occur as a result of a number of pathological conditions, such as diabetes in rats (spontaneous and streptozocin-induced) (Kilzer et al., 1985), cirrhosis of the liver in humans (Henriksen $\varepsilon$ Schlichting, 1981) and portal hypertension in humans (Henriksen et al., 1981). Furthermore, age-related changes have been observed in the structure of microvascular membranes in humans (Darmady et al., 1973; Brancato and Pellegrini, 1973). Endothelial cell-membrane lipid composition has been reported to alter following exposure to increased concentrations of free fatty acid, which might increase the transfer of albumin across the endothelium (Hennig et al., 1984). Whether this mechanism occurs with age is unclear. Liepa et al. (1980) reported an age-related decrease in plasma free fatty acids, while Carlile \& Lacko (1981) found an increase in some rat strains. The increase in apparent volume of distribution of albumin but not in plasma volume or in plasma albumin concentration which was observed in the female WAG/Rij rats at between 12 and 24 months of age suggests that there is an increased amount of extravascular albumin, which could be explained by an increased permeability of the vasculature. The increase in apparent volume of distribution between 24 and 36 months of age was shown to be albumin-molecule specific. On the other hand, injection of albumin isolated from 36-month-old rats into 3-month-old ones did not reveal a higher volume of distribution than with age-matched albumin. This indicates that there must be a basic physiological change (e.g. vascular permeability) prior to the manifestation of the influence of the albumin molecule on the apparent volume of distribution.

What has been said about the nature of the physiological changes is 
also true for the indicated changes in the albumin molecule. Only some speculations can be made with regard to the nature of these changes. With regard to functional changes of the albumin molecule, literature data do not show an altered binding capacity of albumin for several ligands with age, e.g. free fatty acids in humans (Pickart, 1983) and for some drugs e.g. tolbutamide in humans (Miller et al., 1978; Adir et al., 1981). lorazepam in humans (Divoll \& Creenblatt, 1982), pentobarbitone in mice (Jones $\varepsilon$ Pardon, 1980) and nitrazepam in humans (Jochemsen et al., 1983). The occurrence of structurally altered albumin has been described, though not as a function of age. Non-enzymatic glycosylation of serum albumin has been observed by a number of investigators, especially in diabetes in humans (Day et al., 1979; Dolhofer $\&$ Wieland, 1979; Guthrow et al., 1979]. Furthermore, polymeric complexes of albumin as well as fragments of albumin (MW= $45,000,28,000 \& 19,000)$ have been found in normal human pllasma (Kshirsagar et al., 1984).

The increase in albumin elimination with age was found neither to be due to an increased urinary albumin excretion nor to an increase in gastrointestinal protein loss (Chapter III). Fluid-phase endocytosis, measured with 125,-polyvinylpyrrolidone (Chapter 111), however, was shown to be increased at between 12 and 36 months of age. With this technique primarily endocytic uptake from the plasma was measured. This, together with possible albumin-specific uptake processes, could explain the fact that the endocytic uptake process investigated in this study accounts for only $40 \%$ of the total albumin elimination in rats. Although fluid-phase endocytosis is a non-specific process, the albumin-molecule dependency of the increased albumin elimination between 24 and 36 months of age is not necessarily contradictory. If one supposes that the change in the albumin molecule between 24 and 36 months of age leads to an increased permeation of the vasculature for albumin, extravascular albumin concentrations would be increased. This increase would have a direct influence on albumin uptake via extravascular endacytic processes whose rates are directly proportional to the extravascular albumin concentration. In other words, albumin elimina- 
tion could be increased with age by a combination of two processes. Firstly, an increase in fluid-phase endocytic uptake from the blood and secondly, an increased extravascular endocytic uptake which is partly (if not complletely) due to an increased extravascular albumin concentration.

\section{VII-2. ALBUMIN SYNTHESIS AND AGING}

Another objective of the study was to investigate the molecular basis of the age-related increase in albumin synthesis, specifically. whether this change was caused by a change in the level of messenger RNA for albumin and/or by a change in the translational capacity of this messenger RNA. Total post-nuclear RNA and polyribosomes, both membrane-bound and free, were prepared from liver homogenates from female WAG/Rij rats of various ages. Poly $(A)^{+}-R N A$ was isolated from total post-nucllear RNA using oligo(dT)-cellulose chromatography. RNA was also extracted from the polyribosomes.

Albumin mRNA levels were determined in each RNA fraction by molecular hybridization with a single stranded CDNA probe specific for albumin mRNA (Chapter IV). These studies showed an increase in the relative amount of albumin $m R N A$ in total post-nuclear RNA and in membrane-bound polyribosomes at between 12 and 24 months of age. Since both liver weight and total RNA content per gram of liver did not change between these two age-groups, an increase in the absolute amount of albumin mRNA expressed per whole liver could be observed at between 12 and 24 months of age. At between 24 and 36 months of age no change could be seen in either the relative amount of albumin mRNA or in the total RNA content per gram of liver. However, since a significant increase in liver weight was observed to occur between these to age-groups, the absolute amount of albumin mRNA expressed per whole liver also increased. The results obtained with regard to the increase in the relative amount of albumin mRNA between 12 and 24 months of age have been repeated using the technique of dot-blot hybridization (Chapter V). In this experiment the same two-fold increase 
wasi seen.

In order to study the translational capacity of the albumin mRNA, liver polyribosomes (both free and membrane-bound) were isolated from rats of the different age-groups. Mast previous studies have used isopycric centrifugation to separate membrane-bound polyribosomes from free polyribosomes of post-mitochondrial supernatant (Cook $\varepsilon$ Buetow, 1981 ) or to isolate total polyribosomes (Layman et al. "1976; Moudgil et al. " 1979; Shmookler Reis, 1981). However, post-mitochondrial supernatant contains about $30 \%$ of the total membrane-bound and $90 \%$ of the free polyribosomes, and can therefore not be used for a quantitative assessment of the membrane-bound polyribosomes (Blobel $\varepsilon$ Potter. 1967). Furthermore, using this technique free polyribosomes can contribute up to $30^{\circ}$ of the membrane-bound fraction (Blobel $\varepsilon$ Potter, 1967; Lowe et al., 1970). These problems can be eliminated, by using the procedure of Ramsey \& Steele (1976), as in this study. The resullts show that nelther the content of free nor of membrane-bound polyribosomes per gram of liver changes with age. The size distribution of these polyribosomes also does not undergo a change with age. In vitro translational studies using these polyribosomes did not reveal any age-related change in their protein synthetic activity. This result is in contrast with results obtained by Claes-Reckinger et al. (1982) and this disparity might be due to the fact that in their study, polyribosomes isolated from post-mitochondrial supernatant were used.

The translational activity of albumin mRNA was assessed by immunoprecipitation of albumin-like material in the cell-free translation products. It could be seen that albumin synthesis in this system was not increased in proportion to the increase in albumin IRNA between 12 and 24 months of age (50\% versus 1008). This suggests that some, if not all, albumin mRNAs present in the liver of older rats were biologically less active than those found in younger animals. From this study, therefore, it can be concluded that the age-related increase in albumin synthesis in rats is controlled by a two-fold increase in the amount of albumin mRNA and with a $25 \%$ decrease in the translational activity of this mRNA. 
VII-3. CORRELATION BETWEEN ALBUMIN ELIMINATION AND SYNTHESIS WITH AGE

It is of interest to know if the results on albumin elimination can be correlated with the findings on albumin mRNA content and its translational activity. It could be argued that the rate of albumin synthesis is directly correlated with the amount of albumin mRNA and with the translational activity of this mRNA.

The data on the albumin synthesising activity of membrane-bound polyribosomes (Table IV-2B) showed that in 24- and 36-month-old rats this activity was $50 \%$ higher compared with what is seen in 3 - and 12 month-old rats, although the albumin mRNA content was 100 o higher. This indicates that the translational activity of the albumin mRNA in the two older age--groups was only 758 of that in the younger animals. "Albumin synthesis" could be estimated by multiplying the total amount

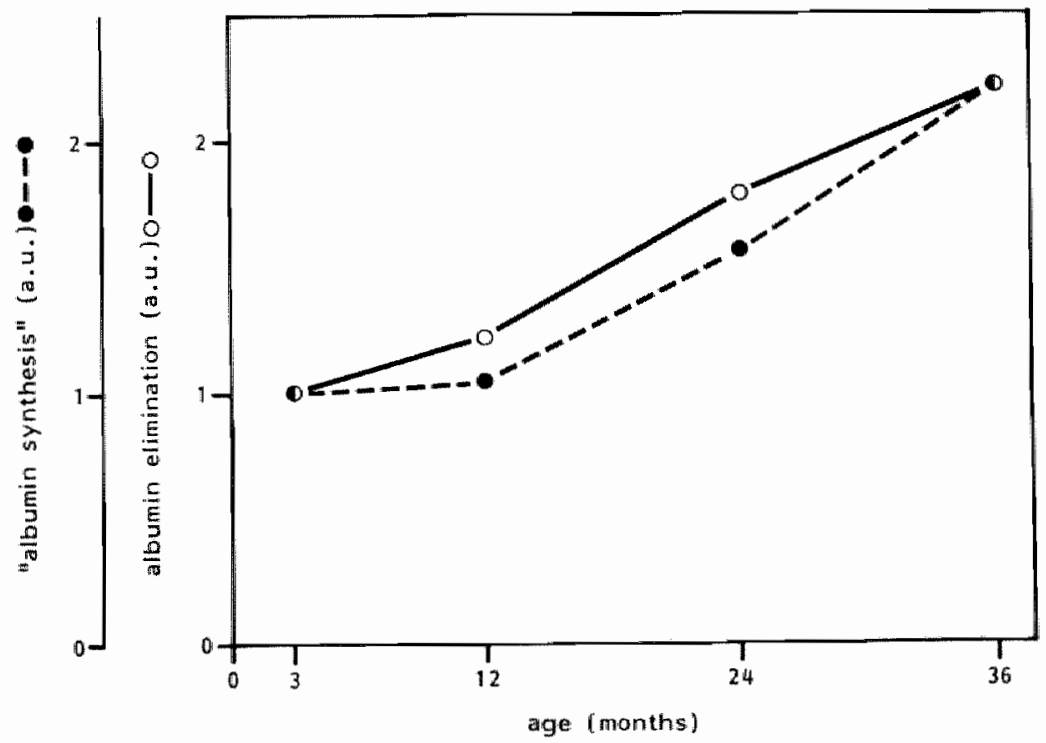

Fig. VII-1. Age-related changes in albumin elimination and albumln synthesis" in female "WAG/Rij rats. Albumin elimination and "albumin synthesis" are expressed in arbitrary units, relative to their value in 3 -manthold rats. 
of albumin mRNA in membrane-bound polyribosomes per whole liver with the translatability of this mRNA (1008 in 3-and 12-month-old rats and $75 \%$ in 24- and 36-month-old ones). Fig. V1l-1 depicts the age-related changes in both albumin elimination and "albumin synthesis". Both factors are expressed relative to their respective levels in 3month-old rats. It can be seen that the increase in albumin synthesis with age is directly correlated with the increase in albumin elimination in these rats (Fig. VII-1). However, the data presented in Chapter VI show that in six individual 36-month-old rats, there is no clear cut correlation between the rate of albumin ellimination and the level of albumin mRNA (Fig. VI-11). This indicates that the relationship is not so simple and an allowance must be made for the translational activity of this mRNA in individual animals in order to produce a reliable correlation.

VI1-4. THE MOLECULAR BASIS OF THE INCREASED ALBUMIN MRNA CONTENT WITH AGE

The observed increase in albumin mRNA content with age may be due to two processes: 1) changes in albumin mRNA synthesis and 2) changes in albumin mRNA turnover. In order to ascertain which of these two processes is the one responsible, studies were performed primarily on the albumin mRNA synthesis rate. The transcription rate of the rat albumin gene was studied in an in vitro system using isolated rat liver nuclei (Chapter $V$ ). In contrast to most other studies, no change with age was observed in total RNA synthetic activity. The rate of transcription of the albumin gene was assessed by hybridization of the newly synthesised RNA molecules to filter-bound albumin cDNA. No age-related changes could be seen in the transcriptional rate of the albumin gene. Furthermore, the amount of albumin specific RNA sequences in rat liver nuclei also showed no age-related changes. These re- 
sults indicate that the observed age-related increase in albumin mRNA content is not controlled by transcriptional processes, but is most probably due to a decrease in the turnover of this mRNA.

One qualitative aspect of the albumin mRNA which showed an agerelated change was the length of the poly $(A)$-tail. The results presented in Chapter IV showed that in the liver of rats of 24 months of age and older, more albumin mRNA was present in the poly (A) ${ }^{-}$-fraction than in the poly $(A)^{+}$-fraction, and this was not observed in younger animals. In order to examine whether shortening of the poly(A)-tails was an overall phenomenon or just specific for the albumin mRNA, studies were performed on the effect of age on the poly $(A)$-tail length of total rat liver mRNA. It was found that the length of the poly (A)-tails in the peak fraction did not change with age ( \pm 130 A-residues). However, a significant change in the relative length distribution was observed. The relative amount of poly(A)-tails longer than 161 A-residues decreased between 12 and 24 months of age, whereas an increase in the relative amount of poly(A)-tails shorter than 115 A-residues was observed. The physiological significance of the age-related decrease in the poly(A)-tail length, especially of albumin mRNA, remains unclear. The function of the poly(A)-tails has been the topic of many discussions (Müller et al., 1985). One hypothesis is that the poly(A)-tail is required for translation of $m R N A$. The results described in Chapter IV of this thesis show that the shortening of the poly(A)-tail of albumin mRNA with age coincides with a diminished translational activity of this mRNA in polyribosomes. However, deadenylated rabbit globin mRNA (Soreq et al., 1979), mouse L cells mRNA (Bard et al., 1974) and total mRNA from quail oviduct (Müller et al., 1976) were compared with the original mRNA with regard to their respective translational activities, and no change was found in the initial rates of translation. A second hypothesis is that poly $(A)$-tails have a stabilizing role. This seems to be in contrast with the conclusion about the increased stability of the albumin mRNA with age. However, literature data have shown no proportionality between stability and poly(A)-tail length (Nudel et al., 1976; Huez et al., 1977). On the other hand, below a length of 10-20 A-resi- 
dues, stability of IRNA was no longer ensured. The decrease in poly $(A)$-tail length of the albumin $m R N A$ with age could be a secondary feature caused by the increased stability. Poly(A)-tails in the cyrtoplasm are continually subjected to the action of nucleases which results in a shortening of the tail over time. Therefore, the observed shortening of the poly (A)-tail of albumin mRNA could be due to its prolonged presence in the cytoplasm. The precise nature of the factors involved in the increased albumin mRNA stability remains to be established.

The results presented in this study demonstrate that this rat strain sustains a number of age-related changes (both at the molecular level and the organ level) that influence the metabolism of rat serum albumin. Despite these changes (which affect both albumin synthesis rates and albumin elimination rates), the aging female WAG/Rij rat is still capable of maintaining an unchanged plasma albumin level and possesses sufficient flexibility, as far as albumin is concerned, to maintain homeostasis with age. 


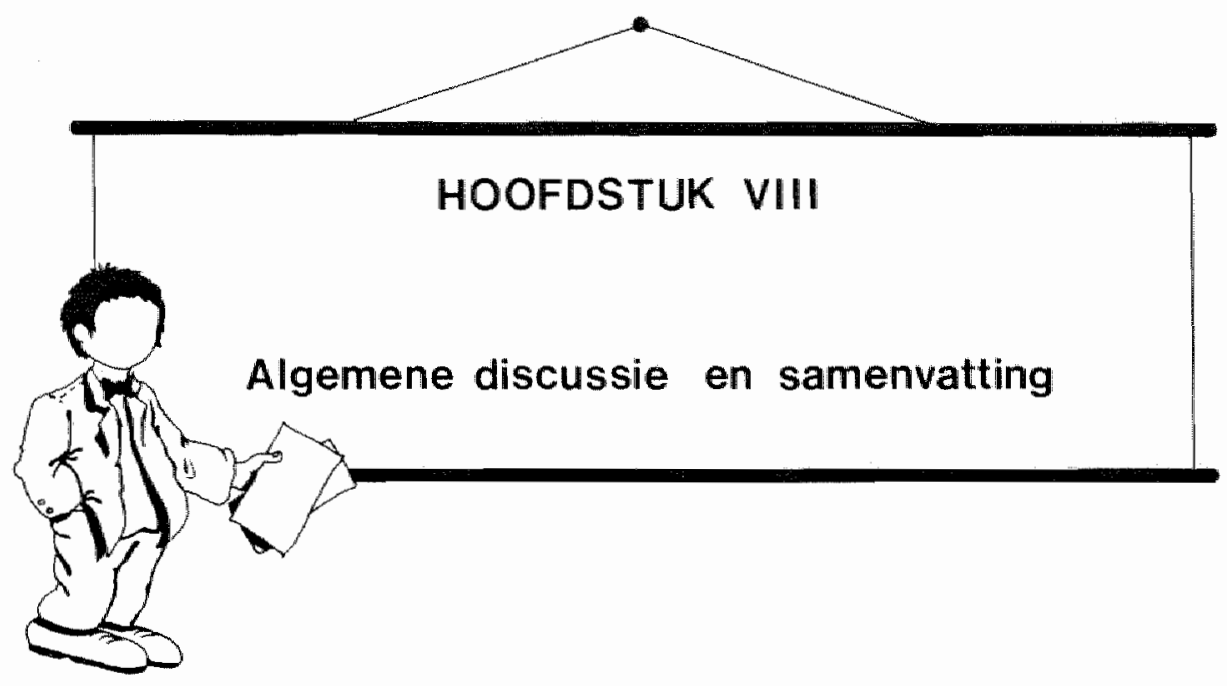

Veroudering is een complex fenomeen, warvan de aard en de oorsprong tot op heden onbekend zijn. Zoals reeds in Hoofdstuk $\|$ is beschreven, is er een grote verscheidenheid aan theorieën voorgesteld om het verouderingsproces te verklaren en een aantal van deze theorieën beschrijven de rol van eiwitten, en van hun synthese en eliminatie, in dit proces. Met betrekking tot eiwitmetabolisme en veroudering zijn er reeds veel studies uitgevoerd (Richardson, 1981; Richardson \& Birchenall-Sparks, 1983; Makrides, 1983). De meeste van deze studies hebben zich echter vooral gericht op eiwitmetabolisme in het algemeen en op veranderingen in die factoren, die een invloed op dit metabolisme kunnen uitoefenen. Vermoedelijk zal het metabolisme van individuele eiwitten echter niet op een uniforme wijze gereguleerd worden met veroudering. Daarom kan het waardeval zijn om de invloed van veroudering op het metabolisme van een specifiek eiwit te bestuderen.

In deze studie is er gekozen voor het serumalbumine van de rat, omdat er in de literatuur beschreven is, dat de synthese van dit elwit 
onder een leeftijdsathankelijke controle staat (Beauchene et al., 1970; Salatka t al., 1971; Ove et al. "1972; Van Bezooijen et al. 1976; Van Bezooijen \& Knook, 1977). Verder is er slechts weinig informatie beschikbaar over de onderliggende mechanismes van deze leeftijdsafhankelijke veranderingen in de albuminesynthese en ook over de invloed van veroudering op de albumineeliminatie. Het doel van deze studie is om inzicht te verkrijgen in de invloed van veroudering op de eliminatie van albumine, in de albumine excretieprocessen, die verantwoordelijk zijn voor mogelijke veranderingen in de albumineeliminatie, en in de moleculaire basis van de leeftijdsafhankelijke veranderingen in de albuminesynthese. Hiertoe zijn al deze aspecten systematisch onderzocht in vrouwelijk WAG/Rij ratten.

\section{VIII-1. ALBUMINEELIMINATIE EN VEROUDERING}

Albumineeliminatiesnelheden werden bepaald in ratten van verschillende leeftijden. Deze bepalingen werden op twee verschillende manieren uitgevoerd. In de eerste plaats werden klaringsstudies uitgevoerd na injectie van albumine, dat geisoleerd werd uit 3 maanden oude ratten. De op deze wijze gevonden leeftijdsafhankelijke veranderingen zijn dan valledig veroorzaakt door veranderingen in de fysiologie van de dieren. In de tweede plaats werden in dezelfde ratten gelijksoortige klaringsstudies uitgewoerd na injectie van albumine, dat geisoleerd werd uit ratten van dezelfde leeftijd als de recipiënten. Mogelijke veranderingen in de eliminatiesnelheid van albumine, die nu gevonden worden, kunnen behalve aan de veranderde fysiologie van de dieren ook aan eventuele veranderingen in het albumine- molecuul toegeschreven worden. De resultaten toonden aan, dat de eliminatiesnelheid van albumine toenam tussen de leeftijden 12 en 36 maanden. Aangezien de toename tussen 12 en 24 maanden onafhankelijk was van de leeftijd van de albumine-donorrat, kon er geconcludeerd worden dat deze toename het gevolg was van een veranderde fysiologie van de rat met het ouder worden. De taename in de albumineeliminatiesnelheid tussen 24 en 36 maanden bleek alleen op te treden na injectie van 
albumine, dat geisoleerd werd uit ratten van dezelfde leeftijd als de recipiënten. Deze toename was daarom het gevolg van een verandering in het albuminemolecuul. Dat naast deze reden ook de veranderde fysiologie nog een belangrijke rol speelde, bleek uit het feit, dat 3 maanden oude ratten geen onderscheid konden maken tussen hun eligen albumine en het albumine, dat uit 36 maanden oude ratten geisoleerd werd. Naast de toename in de eliminatiesnelheid van het albumine werd er ook een toename gevonden in de whole-body albumine pool $f=$ de totale hoeveelheid albumine in het lichaam). De resultaten verkregen uit de longitudinale studie (Hoofdstuk Vl) toonden aan dat de bijdrage van een mogelijk veranderd albuminemolecuul aan de veranderde albumineeliminatie in elke individuele rat optrad, hetgeen ook gold voor toename in de albumineeliminatiesnelheid en in de whole-body albumine pool. Er was slechts één uitzondering. waarbij geen toename in de whole-body albumine pool met veroudering gevonden werd.

De aanwijzingen, die verkregen werden met betrekking tot de leeftijdsafhankelijke veranderingen in de fysiologie van de ratten, waren indirect. Als gevolg hiervan kunnen geen harde uitspraken gedaan worden over de aard van deze veranderingen. Echter, literatuurgegevens wijzen er op dat een toegenomen doorlatbaarheid van de vasculatuur voor albumine op kan treden onder verschillende pathologische condities, zoals diabetes in ratten (spontaan en streptozine geïnduceerd]) (Kilzer et al., 1985), levercirrhose in de mens (Henriksen $\&$ Schlichting. 1981) en portale hypertensie in de mens (Henriksen et al.. 1981). Verder zijn er lleeftijdsafhankelijke veranderingen gevonden in de structuur van de microvasculaire membranen in de mens (Darmady et all. 1973; Brancato E Pellegrini, 1973). De vetsamenstelling van het endotheliale celmembraan blijkt te veranderen na blootstelling aan toegenomen concentraties vrije vetzuren, hetgeen het transport van albumine door het endotheel zou vergemakkelijken [Hennig et al." 1984). Of dit proces ook optreedt met veroudering is onduidelijk. Liepa et al. (1980) beschreven een leeftijdsafhankelijke afname in de concentratie vrije vetzuren in plasma in ratten, terwijl Carlile $\varepsilon$ Lacko (1981) een toename vonden, die echter stam-afhankelijk was. De toe- 
name in het verdelingsvolume wan abbumine, en niet in het plasmavolume noch in de plasmaalbumineconcentratie, die optreedt in vrouwelijke WAG/RI ratten tussen 12 en 24 malanden, suggereert dat er een toegenomen hoeveelheid extravasculair albumine aanwezig is, hetgeen verklaard kan worden door een toegenomen permeabiliteit van de vasculatuur. De toename in het verdelingsvolume voor albumine tussen 24 en 36 manden is afhankelijk van het albuminemolecuul. Daarentegen wordt er na injectie van albumine, geisoleerd wit 36 maanden oude ratten, in 3 maanden oude dieren geen hoger verdelingsvolume gevonden dan na injectie van albumine uit 3 maanden oude ratten. Dit toont aan dat er een basale fysiologische verandering moet zijn opgetreden (bijv. vasculaire permeabiliteit) voordat de invloed van het albumine molecuul op het verdelingswolume manifest kan worden.

Hetgeen er is gezegd over de aard van de fysiologische veranderingen met veroudering gaat ook op voor de leeftijdsafhankelijke veranderingen in het albuminemolecuul. Er kan slechts gespeculeerd worden over de aard van deze veranderingen. Wat betreft functionele veranderingen van het albuminemolecuul wijzen die literatuurgegevens niet op een veranderde bindingscapaciteit van het albumine met veroudering voor endogene liganden, zoals vrije vetzuren in de mens (Pickart, 1983j en voor verschillende geneesmiddelen, zoals tolbutamide in de mens (Miller et al., 1978; Adir et al., 1981), lorazepam in de mens (Divoll \& Greenblatt, 1982), pentobarbital in de muis (Jones 8 Pardon, 1980 ) en nitrazepam in de mens (Jochemsen et al. "1983). Structureel weranderd albumine is beschreven in de literatuur, edach niet met weroudering. Nict-enzymatische glycosylering van serumalbumine is door een aantal onderzoeker's gevonden, en vooral in diabetes in de mens (Day et al., 1979; Dolhofer \& Wieland, 1979; Guthrow et al., 1979). Verder werden er in normal humaan plasma polymere complexen wan albumine gevonden en ook albuminefragmenten ( $M W=45.000,28.000 \varepsilon$ 19.000 D) (Kshirsagar et al ", 1984).

De gevonden toename in de albumineeliminatie met veroudering kon niet worden toegeschrevem aan een toegenomen albumineexcretie in de urine noch aan een toegenomen eiwitverlies via het magdarmkamaal 
(Hoofdstuk 111). Vloeistofpinocytose, gemeten met ${ }^{125}$ I-polyvinylpyrrolidone (Hoofdstuk III) nam toe tussen de leeftijden 12 en 36 maanden. Met deze techniek wordt vooral endocytose vanuit het plasma gemeten. Dit gegeven én de aanname dat er albuminespecifieke opnameprocessen bestaan, kunnen verklaren dat vloeifstofpinocytose, gemeten in deze studie, slechts 408 van de totale albumineeliminatie voor zijn rekening neemt. Hoewel vloeistofpinocytose een niet-specifiek opnameproces is, hoeft de albuminemolecuulafhankelijkheid van de toename in de albumineeliminatie tussen 24 en 36 maanden niet noodzakelijkerwijs hieraan tegenstrijdig te zijn. Als men veronderstelt dat de verandering in het albuminemolecuul tussen 24 en 36 maanden aamleiding geeft tot een toegenomen vasculaire permeabiliteit voor dit veranderde albumine, dan heeft dat tot gevolg dat de extravasculaire albumineconcentraties zullen toenemen. Deze toename heeft dan weer een directe invloed op de albumineopname via extravasculaire endocytotische processen, waarvan de snelheid rechtevenredig is met de extravasculaire albumineconcentratie. Met andere woorden, de eliminatiesnelheid van albumine zou met veroudering kunnen toenemen als een gevolg van twee processen. In de eerste plaats een toename in de vloeistofpinocytotische opname uit het bloed en in de tweede plaats een toename in de extravasculaire endocytotische opname die op zijn minst het gevolg is van een toename in de extravasculaire albumineconcentratie.

\section{VIII-2. ALBUMINESYNTHESE EN VEROUDERINC}

Een andere doelstelling van deze studie was het onderzoek naar de moleculaire basis van de leeftijdsafhankelijke toename in de albuminesynthese. De vraag hierbij was meer specifiek of deze verandering veroorzaakt werd door een veranderd niveau van boodschapper RNA ( $M R N A$ ) voor albumine en/of door een veranderde transleerbaarheid van dit boodschapper RNA. Totaal cytoplasmatisch RNA en polyribosomen, zowel membraangebonden als vrij, werden geisoleerd uit homogenaten van levers van vrouwelijke WAG/Rij ratten van verschillende leeftijd. Poly(A)-bevattend RNA werd geisoleerd uit het cytoplasma- 
tisch RNA door middel van chromatografie over oligo(dT)-cellulose. Verder werd er ook RNA geëxtraheerd uit de polyribosomen.

Het niveau van het albumine-mRNA werd in elke RNA-fractie bepaald door middel van moleculaire hybridizatie met een enkelstrengs cDNA-probe, die specifiek is voor albumine-mRNA (Hoofdstuk IV). Deze studies toonden aan dat de relatieve hoeveelheid van albuminemRNA toenam in thet cytoplasmatisch RNA en in de membraangebonden polyribosomen tussen 12 en 24 maanden. Aangezien zowel het levergewicht als de totale RNA hoeveelheid per gram lever niet veranderen tussen deze twee leeftijden, werd er ook een toename gevonden in de absolute hoeveelheid albumine-mRNA per lever tussen 12 en 24 maanden. Tussen 24 en 36 maanden trad er geen verschil op in de relatieve hoeveelheid van albumine-mRNA noch in de totale RNA hoeveelheid per gram lever. Er werd echter een significante verhoging gevonden in het levergewicht tussen deze twee leeftijden en dus ook in de absolute hoeveelheid albumine-mRNA uitgedrukt per lever. De resultaten, aangaande de verhoging van de relatieve hoeveelheid albumine-mRNA tussen 12 en 24 maanden werden ook verkregen met dot-blot hybridizatie (Hoofdstuk V). In dit experiment werd dezelfde tweevoudige toename gezien.

Om de transleerbaarheid van het albumine-mRNA te bepalen werden polyribosomen (zowel vrij als membraangebonden) geissoleerd uit de levers van ratten van de verschillende leeftijdsgroepen. Een groot gedeelte van de in de literatuur beschreven studies gebruikten isopycnische centriguatie om membraangebonden polyribosomen te scheiden van vrije polyribosomen uit postmitochondriaal supernatant (Cook \& Buetow, 1981) of om totale polyribosomen te isoleren (Layman et al., 1976; Moudgil et al., 1979; Shmookler Reis, 1981). Postmitochondriaal supermatant bevat echter slechts $30 \%$ van de totale hoeveelheid membraangebonden polyribosomen en $90 \%$ van de vrije polyribosomen en kan daarom niet gebruikt worden voor een quantitatieve bepaling van de membraangebonden polyribosomen (Blobel \& Potter, 1967). Daar komt nog bij dat met deze techniek de membraangebonden fraktie tot $30 \%$ verontreinigd kan zijn met vrije polyribosomen (Blobel \& Potter, 1967; 
Lowe et al., 1970). Deze problemen kunnen voorkomen worden door gebruik te maken van de methode van Ramsey \& Steele (1976), zoals in deze studie. De resultaten toonden aan dat de hoeveelheid van zowel vrije als membraangebonden polyribosomen per gram lever niet veranderde met veroudering. De grootteverdeling van deze polyribosomen bleef ook onveranderd met veroudering. In vitro translatieexperimenten met deze polyribosomen toonden geen leeftijdsafhankelijke veranderingen aan in hun eiwitsynthetizerende aktiviteit. Dit resultaat is in tegenspraak met de resultaten van Claes-Reckinger et al. (1982) en deze tegenstrijdigheid zou verklaard kunnen worden door het feit dat zij in hun studies polyribosomen uit postmitochondriaal supernatant isoleerden.

De transleerbaarheid van het albumine-mRNA werd bepaald door middel van immunoprecipitatie van het nieuw gesynthetizeerde albumine in de celvrije translatieproducten. Er werd gevonden dat de albuminesynthese in dit systeem niet in dezelfde mate verhoogd was tussen 12 en 24 maanden als het albumine-mRNA (50\% tegenover 100\%). Dit suggereert dat sommige, zo niet alle, albumine-mRNAs in de lever van oudere ratten biologisch minder aktief zijn dan die in jonge dieren. Uit deze studies kon geconcludeerd worden dat de leeftijdsafhankelijke toename in de albuminesynthese in ratten gereguleerd wordt via een toename van $100 \%$ in de hoeveelheid albumine-mRNA gecombineerd met een afname van $25 \%$ in de transleerbaarheid van dit mRNA.

\section{VIII-3. DE CORRELATIE TUSSEN ALBUMINEELIMINATIE EN} -SYNTHESE MET VEROUDERING

Het is belangrijk om te weten of de resultaten omtrent de eliminatie van albumine gecorreleerd kunnen worden met de vindingen aangaande het albumine-mRNA en de transleerbaarheid van dit mRNA. Met kan nl. stellen dat de albuminesynthesesnelheid direct gerelateerd is aan de hoeveelheid en de transleerbaarheid van het albumine-mRNA.

De gegevens over de albuminesynthetizerende aktiviteit van membraangebonden polyribosomen (Tabel IV-2B) toonden aan dat in 24 en 
36 maanden oude ratten, deze aktiviteit 50\% hoger was dan in 3 en 12 maanden oude dieren, hoewel de hoeveelheïd albumine-mRNA $100 \%$ hoger was. Daarom kan er gesteld worden dat de transleerbaarheid van het albumine-mRNA in de twee oudere leeftijdsgroepen slechts $75 \%$ bedraagt van die in de jongere dieren. "Albuminesynthese" kan benaderd worden door de totale hoeveelheid albumine-mRNA in membraangebonden polyribosomen per hele lever te vermeniguuldigen met de transleerbaarheid van dit mRNA $(100 \%$ in 3 en 12 maanden oude ratten en 758 in 24 en 36 maanden oude dieren). Fig. VIll-1 laat de leeftijdafhankelijke veranderingen zien in de albumineeliminatie en in "albuminesynthese". Beide factoren zijn relatief ten opzichte van hun waarde in 3 maanden oude dieren uitgedrukt. Men kan zien dat de toename in "albuminesynthese" met veroudering gelijk verloopt met de toename in albumineeliminatie (Fig. VIII-1).

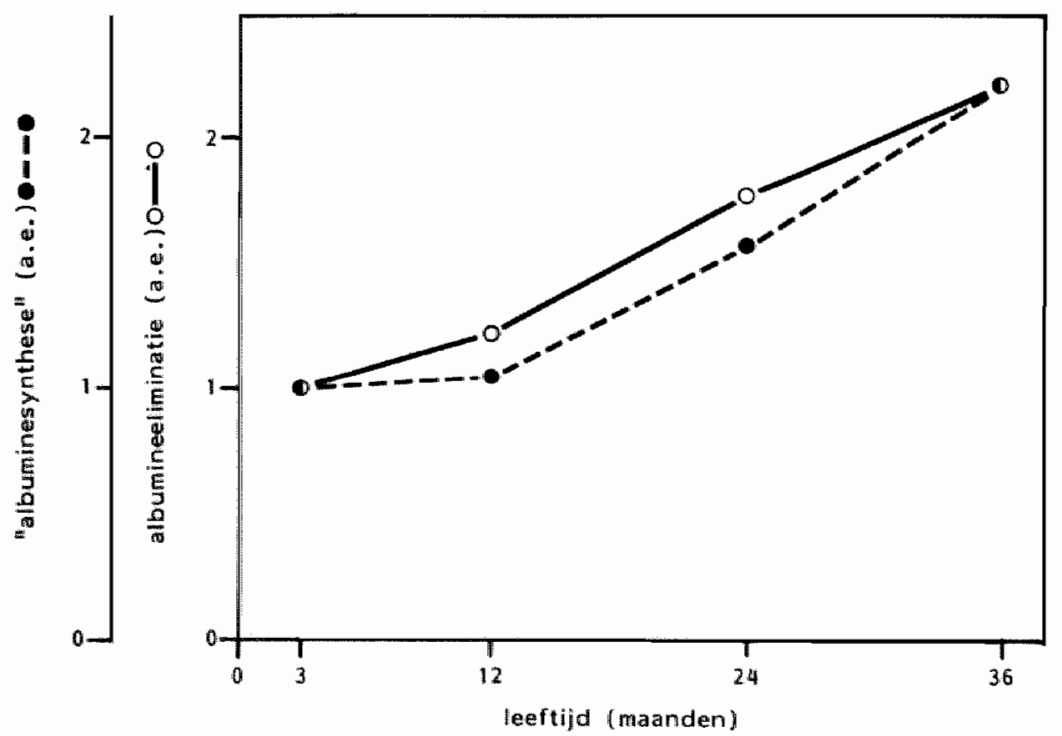

Fig. VII1-1. Leeftijdsafhankelijke veranderingen in albumineelliminatie en in "libuminesynthese" in vrouwel ijke WAC/Ri" ratten. Albumineeliminatie en "albuminesynthese" zijin ultgedrukt in arbitraire eemheden, relatief ten opzichte van hun warde in 3 maanden oude ratten. 
Daarentegen werd in 6 individuele 36 maanden oude ratten geen verband gevonden tussen de albumineeliminatiesnelheid en de hoeveelheid albumine-mRNA (Fig. VI-11). Dit suggereert dat de relatie niet zo eenvoudig ligt en dat in individuele dieren de transleerbaarheid van het albumine-mRNA betrokken moet worden om een betrouwbare correlatie te verkrijgen.

VIII-4 DE MOLECULAIRE BASIS VAN DE TOENAME IN DE HOEVEELHEID ALBUMINE-mRNA MET VEROUDERING

De gevonden toename in de hoeveelheid albumine-mRNA met veroudering kan het gevolg zijn van twee processen: 1) veranderingen in de synthese van dit $\mathrm{RRNA}^{\circ}$ en 2) veranderingen in de turnover van dit mRNA. Om nu er achter te komen welke van deze twee processen verantwoordelijk is voor die toename werden er primair studies uitgevoerd met betrekking tot de synthesesnelheid van het albumine-mRNA. De transcriptiesnelheid van het rattealbuminegen werd gemeten in een in vitro systeem met geisoleerde kernen uit de rattelever (Hoofdstuk $V$ ). In tegenstelling tot de meeste studies werd er geen leeftijdsafhankelijke verandering gevonden in de totale RNA-synthesesnelheid. De transcriptiesnelheid van het albuminegen werd bepaald door middel van hybridizatie van het nieuw gesynthetizeerde RNA met aan een nitrocellulose filter gebonden albumine-cDNA. Geen leeftijdsafhankelijke veranderingen in de transcriptiesnelheid van het albuminegen werd gevonden. Verder kon er aangetoond worden dat de hoeveelheid van albumine-specifieke RNA-sequenties in de kernen van de rattelever gelijk bleef met veroudering. Deze resultaten wijzen er op dat de gevonden toename in de hoeveelheid albumine-mRNA niet gereguleerd wordt door transcriptieprocessen, maar waarschijnlijk het gevolg is van een verlaagde turnover van dit mRNA.

Een qualitatief aspect van het albumine-mRNA, waarvan een leeftijdsafhankelijke verandering is aangetoond, is de lengte van de poly(A)-staart. De resultaten, gepresenteerd in Hoofdstuk IV, lieten zien dat in de lever van ratten van 24 maanden en ouder er meer albumine- 
mRtit a anwezig was in de poly $(A)^{-}{ }^{-}$fraktie dan in de poly $(A)^{+}$-fraktie. Dit werd bill jongere dieren niet wargenomen. Om nu te onderzoeken of het korter worden van de poly(A)-staarten met veroudering een algemeen fenomeen is of slechts specifiek voor het albumine-mRNA, werden er studies uitgevoerd met betrekking tot de invloed van veroudering op de lengte van poly (A)-staarten van totaal rattelever mRNA. Er werd gevonden dat de lengte van de poly(A)-staraten in de piekfraktie niet veranderde met de leeftijd ( 1130 A-residuen). Daarentegen werd er een significante verandering in de relatieve lengteverdeling wargenomen. De relatieve hoeveelheid van poly $(A)-s t a a r t e n$ langer dan 161 A-residuen nam af tussen de leeftijden 12 en 24 maanden, terwijl er een toename optrad in de relatieve hoeveelheid van poly(A)-staarten korter dan 115 A-residuen. De fysiologische betekenis van deze waarneming. vooral ook met betrekking tot het albuminemRNA, blijft onduidelijk. De functie van de poly(A)-staarten is het onderwerp geweest van veel discussies (Müller et al. "1985). Een hypothese is dat de poly (A)-staart noodzakelijk is voor de transleerbaarheid van het IRNA. Inderdaad toonden de resultaten van Haofdstuk IV aan dat het korter worden van de poly(A)-staart van het albumine-mRNA samenviel met de verlaagde transleerbaarheid van dit mRNA in polyribosomes. Daarentegen is er beschreven dat deadenylering van globine-mRNA van het konijn (Soreg et al., 1979), van mRNA uit Lcellen van de muis (Bard et al., 1974) en van mRNA uit het oviduct van de kwartel (Müller et al., 1976) geen invloed had op de initiële translatiesnelheid van deze mRNAs. Een andere hypothese is dat po"y(A)-staarten een stabilizerende rol hebben. Dit lijkt in tegenspraak met de toegenomen stabiliteit van het albuminemRNA met veroudering. Literatuurgegevens, echter, geven aanwijzingen dat er geen evenredigheid bestaat tussen de lengte van de poly(A)-staarten en de stabiliteit van het mRNA (Nudel et al., 1976; Huez et al., 1977). Van de andere kant is de stabiliteit van een mRNA niet meer verzekerd, wanneer de lengte van de poly(A)-staarten korter wordt dan 10-20 A-residuen. Het korter worden van de poly $(A)-s t a a r t$ van het albumine-mRNA kan een secundaire gebeurtenis zijn, die veroorzaakt wordt door de toege- 
nomen stabiliteit van dit mRNA. Poly $(A)$-staarten worden in het cytoplasma continu aangevallen door nucleases, hetgeen resulteert in een korter worden van de poly $(A)$-staart met de tijd. De waargenomen verkorting van de poly(A)-staart van het albumine-mRNA kan dus het gevolg zijn van zijn langer verblijf in het cytoplasma. De aard van de factoren die betrokken zijn bij de verhoging in de stabiliteit van het albumine-mRNA zou nog bepaald moeten worden.

De resultaten, verkregen in deze studie, tonen aan dat deze rattestam een aantal leeftijdsafhankelijke veranderingen ondergat op zowel het moleculaire niveau als het orgaanniveau, die een invloed uitoefenen op het metabolisme van het serumalbumine. Ondanks deze veranderingen (die zowel de albuminesynthese als -eliminatie beinvloeden) is de verouderende vrouwelijke WAG/Rij rat zeer wel in staat om onveranderde plasmaspiegels van het albumine te handhaven en bezit zij voldoende flexibiliteit om met veroudering de homeostase (wat albumine betreft) te handhaven. 

(At the end of each reference the chapter is indicated in which that reference was used)

Adir, J., Miller, A.K. E Vestal, R.E.: Effects of total plasma concentration and age on tolbutamide plasma protein binding. Clin. Pharmacol. Ther. 31 (1981) 488. (ch. VIll)

Alt, J.M., Hackbarth, H., Deerberg, F. \& Stolte, H.: The study of urinary protein excretion in male rats as compared with human proteinuria. Lab. Anim. $14(1980)$ 95. (ch. III \& VI)

Anzai, K., Imazato, C. $\varepsilon$ Goto, S.: mRNA population in the liver, kidney and brain of young and senescent mice: Analysis of in vitro translation products. Mech. Ageing Dev. 23 (1983) 137. (ch. 1)

Arendes, J., Zahn, R.K. \& Müller, W.E.G. : Size determination of poIy(A) after in vitro methylation with radioactive dimethyl sulfate. Anal. Biochem. 101 (1980) 488. (ch. V)

Baliga, B.S., Pronczuli, A.W. \& Munro, H.N.: Regulation of polysome aggregation in a cell free system through amino acid supply. J. Mol. Biol. 34 (1968) 199. (ch. 1)

Bard, E., Efron, D., Marcus, A. E Perry, R.P.: Translational capacity of deadenylated RNA. Cell 1 (1974) 101. (ch. VII)

Baynes, J.W. \& Thorpe, S.R.: Identification of the sites of albumin

catabolism in the rat. Arch. Biochem. Blophys. 206 (1981) 372. (ch. III)

Beauchene, R.E., Roeder, L.M. \& Barrows, C.H.: The effect of age and of ethionine feeding on the ribonucleic acid and protein synthesis of rats. J. Gerontol. 22 (1967) 318. (ch. 1)

Beauchene, R.E., Roeder, L.M. E Barrows, C.H.: The interrelationships of age, tissue protein synthesis, and proteinuria. J. Gerontol. 25 (1970) 359. [ch. I,III,IV,VI \& VIII]

Bensadoun, A. \& Weinstein, D.: Assay of proteins in the presence of interfering materials. Anal. Biochem. 70 (1970) 241. (ch. VI) 
Bernd, A., Batke, E., Zahn, R.K. \& Müller, W.E.C.: Age-dependent gene induction in quail oviduct. $X V$. Alterations of the poly $(A)-$ associated protein pattern and of the poly[(A) chain length of mRNA. Mech. Ageing Dev. 19 (1982) 361. (ch. IV \& $V$ )

Besterman, J.M. A Airhart, J.A., Low, R.B. \& Rannels, D.E.: Pinocytosis and intracellular degradation of exogenous protein: modulation by amino acids. J. Cell Biol. 96 (1983) 1586. (ch. IIl)

Besterman, J.M. \& Low, R.B.: Endocytosis: a review of mechanisms and plasma membrane dynamics. Biochem. J. 210 (1983) 1. (ch. III) Bielka, H., Schneiders, 1., Venker, L. \& Henske, A.: Zur Altersabhängigkeit der Proteinbiosynthese. Z. für Alternsforsch. 31 (1976) 7. (ch. 1)

Birchenall-Sparks, M.C., Roberts, M.S., Rutherford, M.S. E Richardson, A.: The effect of aging on the structure and function of liver messenger RNA. Mech. Ageing Dev. 32 (1985) 99. (ch. \& \& V)

Björksten, J.: Crosslinkage and the aging process. In: Theoretical Aspects of Aging (Rockstein, M. Sussman, M.L. \& Chesky, J., eds.) Academic Press, New York (1974) 43. (ch. 1)

Blazejowski, C.A. \& Webster, G.C.: Decreased rates of protein synthesis by cell-free preparations from different organs of aging mice. Mech. Ageing Dev. 21 (1983) 345. (ch. I)

Blazejowski, C.A. \& Webster, G.C.: Effect of age on peptide chain initiation and elongation in preparations from brain, liver, kidney and skeletal muscle of the C57BL/6」 mouse. Mech. Ageing Dev. 25 (1984) 323. (ch. I)

Blobel, G. E Potter, V.R.: Studies on free and membrane-bound ribosomes in rat liver. 1. Distribution as related to total cellular RNA. J. Mol. Biol. 26 (1967) 279. (ch. IV $\varepsilon$ VII)

Blobel, G. E Dobberstein, B.: Transfer of proteins across membranes. I. Presence of proteolytically processed and unprocessed nascent immunogllobulin light chains on membrane-bound ribosomes of murine myeloma. J. Cell Biol. 67 (1975) 835. (ch. I) 
Bolla, R.I. E Denckla, W.D.: Effect of hypophysectomy on Viver ribonu cleic acid synthesis in aging rats. Biochem. J. 184 (1979) 669. (ch. I \& V]

Bolla, R.I. \& Greenblatt, C.: Age-related changes in rat liver total protein and transferrin synthesis. Age 5 (1982) 72. (ch. 1)

Brancato, R. \& Pellegrini, M.S.F.: Etude ultramicroscopique sur le vieillissement des capillaires de la conjonctive. Ophthalmologica, 166 (1973) 105. (ch. VII)

Brawerman, G.: Characteristics and significance of the polyadenylate sequence in mammalian messenger RNA. Prog. Nucl. Aciod Res. Mol. Biol. 17 (1976) 117. (ch. V)

Britton, V.J., Sherman, F.G \& Florini, J.R.: Effect of agle on RNA synthesis by nuclei and soluble RNA palymerases from liver and muscle of C57BL/6J mice. J. Gerontol. 27 (1972) 188. (ch. I)

Brown, J.R.: Structural origins of mammalian albumin. Fed. Proc. 35 (1976) 2141. (ch. 1)

Buetow, D.E. \& Gandhi, P.S.: Decreased protein synthesis by microsomes isolated from senescent rat liver. Exp. Gerontol. 8 (1973) 243. (ch. 1)

Burek, J.D.: Pathology of aging rats, CRC Press, West Palm Beach (1978). (ch. VI)

Burrows, R.B. \& Davison, P.F.: Protein catabolism in cultures of hepatocytes derived from mice of various ages. Mech. Ageing Dev. $19(1982) 85$. (ch. 1)

Carlile, S.T. \& Lacko, A.G.: Strain differences in the age-related changes of rat lipoprotein metabolism. Comp. Biochem. Physiol. 70B (1981) 753. (ch. VII)

Castle, T., Katz, A. \& Richardson, A.: Comparison of RNA synthesis by liver nuclei from rats of various ages. Mech. Ageing Dev. 8 (1978) 383. (ch. I \& V)

Chatterjee, B., Nath, S.T. \& Roy, A.K.: Differential regulation of the messenger RNA for three major senescence marker proteins in male rat liver. J. Biol. Chem. 256 (1981) 5939. (ch. 1) 
Chen, J.C., Ove. P. L Lansing, A.ll: In vitro synthesis of microsomal protein and albumin in young and old rats. Biochim. Biophys. Acta 312 (1973) 598. (ch. I \& IV)

Chirgwin, J.M., Przybyla, A.E., MacDonald, R.J. \& Rutter, W.J.:

Isolation of biologically active ribonucleic acid from sources enriched in ribonuclease. Biochemistry 18 (1979) 5294. (ch. V)

Claes-Reckinger, N., Vandenhaute, J., Van Bezooijen, C.F.A. \& Delcour, J.: Functional properties of rat liver protein synthesizing machinery in relation with aging. Exp. Gerontol. 17 (1982) 281. (ch. I\& VII)

Comolli, R., Ferioli, M.E. \& Azzola, S.: Protein turnover of the lysosomal and mitochondrial fractions of rat liver during aging. Exp. Gerontol. 7 (1972) 369. (ch. 1)

Comolli, R.: Polyamine effects on ${ }^{14} \mathrm{C}$-leucine transfer to microsomal protein in a rat liver cell-free system during aging. Exp. Gerontol. 8 (1973) 307. (ch.1)

Comolli, R.: Deficiency in accessory protein of native 405 ribosome subunits in the liver of aging rats. Exp. Gerontol. 10 (1975) 31. (ch. I)

Comolli, R., Schubert, A.C. \& Delpiano, C.: Dissociation of monomer ribosomes into subunits by liver and hepatoma DF extracts and its relation with age. Exp. Gerontol. 12 (1977) 89. (ch. I)

Coniglio, J.J., Liu, D.S.H. \& Richardson, A.: A comparison of protein synthesis by liver parenchymal cells isolated from Fischer F344 rats of various ages. Mech. Ageing Dev. 11 (1979) 77. (ch.1)

Cook, J.R. E Buetow, D.E.: Decreased protein synthesis by polysomes, tRNA and aminoacyl-tRNA synthetases isolated from senescent rat liver. Mech. Ageing Dev. 17 (1981) 41. (ch. VII)

Corkin, S.: Acetylcholine, aging and Alzheimer's disease. Implications for treatment. Trends in Neurosciences 4 (1981) 287. (ch. 1)

Crane, L.J. \& Miller, D.L.: A solid-phase radio-immuno assay for fibrinogen. Anal. Biochem. $64(1975) 60$, (ch. IV) 
Curtis, H.J.: Biological Mechanisms of Aging. Charles C. Thomas, Springfield, Illinois (1966). (ch. 1)

Darmady, E.M., Offer, J. \& Woodhouse, M.A.: The parameters of the ageing kidney. J. Pathol. 109 (1973) 195. (ch. VIll)

Davi, A., Raina, L. E Sarkar, N.K.: Effect of age on some aspects of the synthesis of ribonucleic acid. Nature 212 (1966) 474 . (ch. 1)

Day, J.F., Thorpe, S.R. \& Baynes, J.W.: Nonenzymatically glycosylated albumin. J. Biol. Chem. 254 (1979) 595. (ch. VII)

Denckla, W.D.: System analysis of possible mechanisms of mammalian aging. Mech. Ageing Dev. 6 (1977) 143. (ch. I \& V)

Dilella, A.G., Chiang, J.Y.L. \& Steggles, A.W.: The quantitation of liver cytochrome $\mathrm{P} 450-\mathrm{LM}_{2}$ mRNA in rabbits of different ages and after phenobarbital treatment. Mech. Ageing Dev. 19 (1982) 113. (ch. I)

Divoll, M. \& Greenblatt, D.J.: Effect of age and sex on lorazepam protein binding. J. Pharm. Pharmacol. 34 (1982) 122. (ch. VII)

Dolhofer, R. \& Wieland, O.H.: Glycosylation of serum albumin: elevated glycosyl-albumin in diabetic patients. FEBS Letters 103 (1979) 282. (ch. VII)

Duncan, R. \& Lloyd, J.B.: Pinocytosis in the rat visceral yolk sac. Effects of temperature, metabolic inhibitors and some other modifiers. Biochim. Biophys. Acta 544 (1978) 674. (ch. III)

Edwards, K., Fleisher, B., Dryburgh, H., Fleisher, S. and Schreiber, G.: The distribution of albumin precursor protein and albumin in liver. Biochem. Biophys. Res. Commun. 72 (1976) 310 . (ch. I)

Ehrenreich, B.A. \& Cohn, Z.A.: The uptake and digestion of iodinated human serum albumin by macrophages in vitro. J. Exp. Med. 126 (1967) 941 . (ch. III)

Enwonwu, C.O. \& Munro, H.N.: Rate of RNA turnover in rat liver in relation to intake of protein. Arch. Biochem. Blophys. 138 (1970) 532. (ch. 1)

Eurich, R.E., Lindner, J. \& Schröder, D.: Investigations of metabolic parameters in male and female rats during the course of life. Mech. Ageing Dev. 14 (1980) 317. (ch. 1) 
Failla, G.: The aging process and carcinogenesis. Ann. N.Y. Acad. Sci. 71 (1958) 1124. (ch. 1)

Fitzpatrick, F.A. \& Wynalda, M.A.: Albumin-lipid interactions: Prostaglandin stability as a probe for characterizing binding sites on vertebrate albumin. Biochemistry 20 (1981) 6129. (ch. I)

Fitzpatrick, F.A. \& Wynalda, M.A..: Albumin-catalyzed metabolism of prostaglandin $D_{2}$. Identification of products formed in vitro. J. Biol. Chem. 258 (1983) 11713. (ch. I)

Fleck, A. \& Munro, H.N.: The precision of ultraviolet absorption measurements in the Schmidt-Thannhauser procedure for nucleic acid estimation. Biochim. Biophys. Acta. 55 (1962) 571. (ch. IV \& $\mathrm{V} \mid)$

Fleischer, A.B., Shurmantine, W.O.. Thompson, F.L., Forker, E.L. \& Luxon, B.A.: Effect of a transported ligand on the binding of albumin to rat liver cells. J. Lab. Clin. Med. 105 (1985) 185. (ch. 1)

Florini, J.R.: Differences in enzyme levels and physiological processes in mice of different ages. Exp. Aging Res. 1 (1975) 137. (ch. 1)

Fog, R. \& Pakkenberg, H.: Age-related changes in ${ }^{3} \mathrm{H}$-Uridine uptake in the mouse. J. Gerontol. 36 (1981) 680. (ch. I)

Franz, C.P., Croze, E.M., Morré, D.J. \& Schreiber, G.: Albumin secreted by rat liver bypasses Golgi apparatus cisternae. Biachim. Biophys. Acta 678 (1981) 395. (ch. I)

Gabius, H.J., Engelhardt, R., Deerberg, F. \& Cramer, F.: Age-related changes in different steps of protein synthesis of liver and kianeys of rats. FEBS Letters 160 (1983) 115. (ch. 1)

Gibaldi, M. \& Perrier, D.: Pharmacokinetics, Marcel Dekker, New York (1975). (ch. II \& III)

Gibas, M.A. \& Harman, D.: Ribonucleic acid synthesis by nuclei isolated from rats of different ages. J. Gerontol. 25 (1970) 105. (ch. I $\&$ VJ

Gray, J.E., Van Zwieten, M.J. \& Hollander, C.F.: Early light microscopic changes of chronic progressive nephrosis in several strains of aging laboratory rats. J. Gerontol. 37 (1982) 142. (ch. VI) 
Grossman, S.B., Yap, S.H. \& Shafritz, D.A.: Influence of chronic renal failure on protein synthesis and albumin metabolism in rat liver. J. Clin. Invest. 59 (1977) 869. (ch. IV)

Guertin, M. Baril, P. "Bartkowiak, J., Anderson, A. E Bélanger,

L.: Rapid suppression of $\alpha_{1}$-fetoprotein gene transcription by dexamethason in developing rat liver. Biochemistry 22 (1983) 4296. (ch. V)

Guigoz, $Y$. \& Wellinger, R.: Tyrosine aminotransferase mRNA and tryptophan axygenase mRNA induction by physiological stress or by dexamethasone in adult and senescent rat. In: Pharmacological, Morphological and Physiological Aspects of Liver Aging (Van Bezooijen, C.F.A., ed.) EURAGE, Rijswijk (1984) 25. (ch. I)

Guthrow, C.E., Morris, M.A., Day, J.F., Thorpe, S.R. \& Baynes, J.W.: Enhanced nonenzymatic glycosylation of human serum albumin in diabetes mellitus. Prac. Natl. Acad. Sci. USA 76 (1979) 4258. (ch. VII)

Hallthaler, V.C., Reifegerste, D., Köhler, R. E Rötzsch. W.: Zur

Molekularbiologie des Alterns. VII. Mitteillung: Einfluss der Cytosolfraktion auf die Aminosäurinkorporation durch Rattenlebermikrosomen in Abhängigkeit vom Lebensalter. Z. Alternsforsch. 31 (1976) 457. (ch. 1)

Hawkins, J.D.: Catabolism of rat serum albumin. Biochem. J. 80 (1961) 210. (ch. 1)

Helmkamp, R.W., Contreras, H.A. \& Bale W.F.: $1^{131}$-labelling of proteins by the iodine monochloride method. Int. J. Appl. Radiat. Isot. 18 (1967) 737. (ch. II \& VI)

Hennig, B., Shasby, D.M., Fulton, A.B. E Spector, A.A.: Exposure to free fatty acid increases the transfer of albumin across cultured endothelial monolayers. Arteriosclerosis 4 (1984) 489. (ch. VII)

Henriksen, J.H. \& Schlichting, P.: Increased extravasation and lymphatic return rate of albumin during diuretic treatment of ascites in patients with liver cirrhosis. Scand. J. Clin. Lab. Invest. 41 (1981) 589. (ch. VII) 
Henriksen, J.H., Parving, H.H., Christiansen, L.A., Lassen, N.A., Ring-Larsen, H. \& Winkler, K.: The effect of ascitic fluid hydrostatic pressure on albumin extravasation rate in patients with cirrhosis of the liver. Scand. J. Clin. Lab. Invest. 41 (1981) 601. (ch. VII) Heywood, S.M., Kennedy, D.S. \& Bester, A.J.: Separation of specific initiation factors involved in the translation of myosin and myoglobin messenger RNAs and the isolation of new RNA involved in the translation. Proc. Natl. Acad. Sci. USA 71 (1974) 2428. (ch. IV)

Hicks, S.J., Drysdale, J.W. \& Munro, H.N.: Preferential synthesis of ferritin and albumin by different populations of liver polysomes. Science 164 (1969) 584. (ch. I)

Hofer, E., Alonso, A., Krieg, L., Schätzle, U. \& Sekeris, C.E.: Purification of albumin mRNA from rat liver. Content of albumin-specific sequences in cytoplasmic and nuclear RNA. Eur. J. Biochem. 97 (1979) 455. (ch. 1)

Hollander, C.F.: Current experience using the laboratory rat in aging studies. Lab. Anim. Sci. 26 (1976) 320. (ch. 1)

Horbach, G.J.M.J., Yap, S.H. \& Van Bezooijen, C.F.A.: Age-related changes in albumin elimination in female WAG/Rij rats. Biachem. J. 216 (1983) 309. (ch. III, IV \& V)

Horbach, G.J.M.J., Princen, H.M.G., Van der Kroef, M., Van Bezooijen, C.F.A. G Yap, S.H.: Changes in the sequence content of albumin mRNA and in its translational activity in the rat liver with age. Biochim. Biophys. Acta 783 (1984a) 60. (ch. 1)

Horbach, G.J.M.J., Van Leeuwen, R.E.W., Yap, S.H. \& Van Bezooijen, C.F.A.: Age-related changes in fluid-phase endocytosis in female WAC/Rij rats. In: Pharmacological, Morphological and Physiological aspects of liver aging (Van Bezooijen, C.F.A., ed.) EURAGE, Rijswijk (1984b) 19. (ch. III)

Horbach, G.J.M.J., Van der Boom, H. , Van Bezooijen, C.F.A. \& Yap, S.H.: Molecular aspects of age-related changes in albumin synthesis in rats. In: Liver, Drugs and Aging, vol.7. (Van Bezooijen, C.F.A., Miglio, F. \& Knook, D.L., eds.) EURAGE, Rijswijk (1986a) 121. (ch. $V)$ 
Horbach, G.J.M.J., Van Leeuwen, R.E.W., Yap, S.H. \& Van Bezooijen, C.F.A.: Changes in fluid-phase endocytosis in the rat with age and their relation to total albumin elimination. Mech. Ageing Dev. 33 (1986b) 305 (ch. III)

Housman, D., Skoutchi, A., Forget, B.G. \& Benz, E.J.: Use of a cDNA as a hybridization probe for globin mRNA. Ann. N.Y" . Acad. Sci. 241 (1974) 280. (ch. IV \& VI)

Hrachovec, J.P.: The effect of age on tissue protein synthesis. Gerontologia 17 (1971) 75. (ch. 1)

Huez, G., Marbaix, G., Burny, A., Hubert, E., Leclercq, M. , Cleuter. Y.. Chantrenne, H., Soreq, H. \& Littauer, U.Z.: Degradation of deadenylated rabbit a-globin mRNA in Xenopus oocytes is associated with its translation. Nature 266 (1977) 473. (ch. VII)

Hütter, J.F., Piper, H.M. \& Spieckermann, P.G.: Kinetic analysis of myocardial fatty acid oxidation suggesting an albumin receptor mediated uptake process. J. Mol. Cell. Cardiol. 16 (1984) 219. (ch. 1)

Ikehara, Y., Oda, K. \& Kato, K.: Conversion of proalbumin into serum albumin in the secretory vesicles of rat liver. Biochem. Biophys. Res. Commun. 72 (1976) 319. (ch. 1)

Jacobus, S. \& Gershon, D.: Age-related changes in inducible mouse liver enzymes: ornithine decarboxylase and tyrosine aminotransferase. Mech. Ageing Dev. 12 (1980) 311. (ch. 1)

Jagodzinski, L.L., Sargent, T.D., Yang, M. \& Bonner, J.: The albumin gene family. In: Developmental Biology using Purified Genes. (Brown, D.D., ed.). Acad. Press, New York (1981) 41. (ch. I) Jeffries, G.H., Holman, H.R. \& Sleisenger, M.H.: Plasma proteins and the gastrointestinal tract. New England J. Med. 266 (1962) 652. (ch. III)

Jochemsen, R., Van Beusekom, B.R., Spoelstra, P. .Janssens, A.R. $\varepsilon$ Breimer, D.D.: Effect of age and liver cirrhosis on the pharmacokinetics of nitrazepam. Brit. J. Clin. Pharmacol. 15 (1983) 295. (ch. Vil) 
Jones, T.W.G. E Pardon, 1.S.: The effect of age on the plasma protein binding of pentobarbitone in the mouse. A brief note. Mech. Ageing Dev. 14 (1980) 409. (ch. VIll)

Judah, J.D. \& Quinn, P.S.: On the biosynthesis of serum albumin. Trends Biochem. Sci. 1 (1976) 107. (ch. 1)

Kanungo, M.S., Joul, O.\& Ready, K.R.: Concomitant studies on RNA and protein synthesis in tissues of rats of various ages. Exp. Gerontol. 5 (1970) 261. (ch. 1)

Katz, J., Bonorris, G. \& Sellers, A.L.: Albumin metabolism in aminonucleoside nephrotic rats. J. Lab. Clin. Med. 62 (1963) 910. (ch. 1)

Keeler, R.: The effect of the bilateral nephrectomy on the production and distribution of muramydase (lysozyme in the rat). Can. J. Phys. Pharm. 48 (1970) 131. (ch. III)

Keller, G.H. \& Taylor, J.M.: Effect of hypophysectomy on the synthesis of rat liver albumin. J. Biol. Chem. 251 (1976) 3768. (ch. 1)

Kernhoff, L.M., Pimstone, B.L., Solomon, J. E Brock, J.F.: The effect of hypophysectomy and growth hormone replacement on albumin synthesis and catabolism in the rat. Biochem. J. 124 (1971) 529. [ch. 1)

Khawaja, J.A.: Influence of spermine on aminoacid incorporation by free, bound and reattached ribosomes from rat liver. Acta. Chem. Scand. 26 (1972) 3450. (ch. I)

Kikawa, Y., Narumiya, S., Fukushima, M., Wakatsuka, H. E Hayaishi, O.: 9-Deoxy- $\Delta^{9}, \Delta^{12}-13,14$-dihydroprostaglandin $D_{2}$, a metabolite of prostaglandin $\mathrm{D}_{2}$ formed in human plasma. Proc. Natl. Acad. Sci. USA 81 (1984) 1317. (ch. 1)

Kilzer, P., Chang, K., Marvel, J., Rowold, E., Jaudes, P., Ullensvang, S.. Kilo, C. \& Williamson, J.R.: Albumin permeation of new vessels is increased in diabetic rats. Diabetes 34 (1985) 333. (ch. VII $)$

Knook, D.L.: Aging of cells: accident or programme ? Endeavour 6 (1982) 162. (ch. 1) 
Kreamer, W., Zorich, N., Liu, D.S.H. \& Richardson, A.: Effect of age on RNA synthesis by rat hepatocytes. Exp. Gerontol. 14 (1979) 27. (ch. 1)

Kshirsagar, B., Wilson, B. \& Wiggins, R.C.: Polymeric complexes and fragments of albumin in normal human plasma. Clin. Chim. Acta 143 (1984) 265. [ch. VII]

Kunnath, L. \& Locker, J.: Developmental changes in the methylation of the rat albumin and $\alpha$-fetoprotein genes. EMBO Journal 2 (1983) 317. (ch. I)

Kurtz, D.1.: The effect of aging on in vitro fidelity of translation in mouse liver. Biochim. Biophys. Acta 407 (1975) 479. (ch. I)

Kurtz, D.I.: A decrease in the number of active mouse liver ribosomes during aging. Exp. Gerontol. 13 (1978) 397. (ch. 1)

Lamers, W.H., Hanson, R.W. \& Meisner, H.W.: cAMP stimulates transcription of the gene for cytosolic phosphoenolpyruvate carboxykinase in rat liver nuclei. Proc. Natl. Acad. Sci. USA 79 (1982) 5137. (ch. V)

Lavie, L., Reznick, A.Z. \& Gershon, D.: Decreased protein and puromycinyl-peptide degradation in livers of senescent mice. Biochem. J. 202 (1982) 47. (ch. I)

Layman, D.K., Ricca, G.A. \& Richardson, A.: The effect of age on protein synthesis and ribosome aggregation to messenger RNA in rat. Arch. Biochem. Biophys. 173 (1976) 246. (ch. I \& VII)

Liao, W.S.L., Conn, A.R. \& Taylor, J.M.: Changes in rat $\alpha_{1}$-fetoprotein and albumin mRNA levels during fetal and neonatal development. J. Biol. Chem. 255 (1980) 10036. (ch. I)

Liepa, G.U., Masoro, E.J., Bertrand, H.A. \& YU, B.P.: Food restriction as a modulator of age-related changes in serum lipids. Am. J. Physiology 238 (1980) E253. (ch. VII)

Lim, L., Canellakis, N.Z. \& Canellakis, E.S.: Metabolism of naturally occurring homopolymers. II. Characterization of adenine-rich polynucleotides of mouse liver ribosomes. Biochim. Biophys. Acta 209 (1970) 128. (ch. I) 
Lindell, T.J., Duffy, J.J. \& Byrnes, B.: Transcription in aging: The response of rat liver RNA polymerases to cyclohexamide in vivo. Mech. Ageing Dev. 19 (1982) 63. (ch. I \& V)

Lowe, D., Reid, E. E Hallinan, T.: Importance of centrifugation time and homogenate concentration for isolating rat liver free polysomes. Effect of fasting. FEBS Letters 6 (1970) 114. (ch. VII)

Lowry, O.H., Rosebrough, N.J., Farr, A.L. \& Randall, R.J.: Protein measurement with the folin phenol reagent. J. Biol. Chem. 193 (1951) 265. (ch. VI)

Mainwaring, W.I.P.: Changes in the ribonucleic acid metabolism of aging mouse tissues with particular reference to the prostate gland. Biochem. J. 110 [1968) 79. (ch. I)

Mainwaring, W.I.P.: Effect of age on protein synthesis in mouse liver. Biochem. J. 113 (1969) 869. (ch. I)

Makrides, S.C.: Protein synthesis and degradation during aging and senescence. Biol. Rev. 58 (1983) 343. (ch. I \& VIll)

Mancini, G., Carbonara, A.O. \& Heremans, J.F.: Immunochemical quantitation of antigens by single radial immunodiffusion. Immunochemistry 2 (1965) 235. (ch. II, III \& VI)

Mann, D.M.A., Neary, D., Yates, P.O., Lincoln, J., Snowden, J.S. \& Stanworth, P.: Neurofibrillary pathology and protein synthetic capability in nerve cells in Alzheimer's disease. Neuropathology and Applied Neurobiology 7 (1981) 37. (ch. 1)

Martin, G.M.: Genetic syndromes in man with potential relevance to the pathobiology of ageing. In: Genetic effects on ageing. Birth defects: original article series (Bergsma, D., Harrison, D.E. $\varepsilon$ Paul, N.W., eds.) The National Foundation, March of Dimes, A.R. Liss, New York (1977). (ch. 1)

Martin, H. \& Martin, R.: RNA metabolism and ageing. Akt. Gerontol. 7 (1977) 247-252, (ch. I)

Marzluff, W.F. \& Huang, R.C.C.: Transcription of RNA in isolated nuclei. In: Transcription and translation. A practical approach (Hames, B.D. \& Higgins, S.J., eds.) IRL Press, Oxford, Washington DC (1984) 89 . (ch. V) 
Matthews, M.B., Pragnell, I.B., Osborn, M. \& Arnstein, H.R.V.: Stimulation by reticulocyte initiation factors of protein synthesis in a cell free system from Krebs 11 ascites cells. Biochim. Biophys. Acta 287 (1972) 113. (ch. IV)

Maudsley, D.V.: Regulations of polyamine biosynthesis. Biochem. Pharmacol. 38 (1979) 153. (ch. 1)

McFarlane, A.S.: Labelling of plasma proteins with radioactive iodine. Biochem. J. 62 (1956) 135. (ch. $11 \&$ VI)

McFarlane, A.S. \& Koj, A.: Short term measurement of catabolic rates using iadine labelled plasma proteins. J. Clin. Invest. 49 (1970) 1903. (ch. I)

McMartin, D.N. \& Schedlbauer, L.M.: Incorporation of $\left({ }^{14} \mathrm{C}\right)$-leucine into protein and tubulin by brain slices from young and old mice. J. Gerontol. 30 (1975) 132. (ch. I)

McNurlan, M.A., Tomkins, A.M. \& Garlick, P.J.: The effect of starvation on the rate of protein synthesis in rat liver and smalt intestine. Biochem. J. 178 (1979) 373. (ch. I)

Meisner, H.W., Lamers, w.H. \& Hanson, R.W.: Cyclic AMP and the synthesis of phosphoenolpyruvate carboxykinase (GTP) mRNA. Trends Biochem. Sci. 8 (1983) 165. (ch. V)

Miller, A.K., Adir, J. \& Vestal, R.E.: Tolbutamide binding to plasma proteins of young and old human subjects. J. Pharm. Sci. 67 (1978) 1192. (ch. VIl)

Minty, A.J. \& Gross, F.: Coding potential of non-polyadenylated messenger RNA in mouse friend cells. J. Mol. Biol. 139 (1980) 61. (ch. 1)

Moldave, K., Harris, J.., Sabo, W. \& Sadnik, I.: Protein synthesis and aging: Studies with cell-free mamalian systems. Fed. Proc. Am. Soc. Exp. Biol. 38 (1979) 1979. (ch. I \& IV)

Moore, R.E. . Goldsworthy, T.L. \& Pitol, H.C.: Turnover of 3'-polyadenylate-containing RNA in livers from aged, partially hepatectomized, neonatal, and Morris $5123 \mathrm{C}$ hepatoma-bearing rats. Cancer Res. 40 (1980) 1449. (ch. 1) 
Mori, N., Mizuno, D. $\varepsilon$ Coto, S.: Conservation of ribosomal fidelity during ageing. Mech. Ageing Dev. 10 (1979) 379. (ch. 1)

Moudgil, P.G., Cook, J.R. \& Buetow, D.E.: The proportion of ribosomes active in protein synthesis and the content of polyribosomal poly(A)-containing RNA in adult and senescent rat liver. Gerontology 25 (1979) 322. (ch. I \& VII)

Muglia, K. \& Locker, J.: Developmental regulation of albumin and $\alpha$-fetoprotein gene expression in the rat. Nucl. Ac. Res. 12 (1984) 6751. (ch. 1)

Müller, W.E.G., Seibert, G., Steffen, R. \& Zahn, R.K.: Endoribonuclease IV.2. Further investigation on the specificity. Eur. J. Biochem. 70 (1976) 249. (ch. Vil)

Müller, W.E.G., Agutter, P.S., Bernd, A., Bachmann, M. E Schröder, H.C.: Role of post-transcriptional events in aging: Consequences of gene experssion in eukaryotic cells. In: Thresholds in aging (Bergener, M., Ermini, M. \& Stähelin, H.B., eds.). Academic Press, London (1985) 21. (ch. VII)

Munniksma, J., Noteborn, M., Kooistra, T., Stienstra, S., Bouma, J.M.W., Gruber, M., Brouwer, A., Praaning-Van Dalen, D.P. \& Knook, D.L.: Fluid-phase endocytosis by rat liver and spleen: Experiments with 125 -labelled poly(vinylpyrrolidone) in vivo. Biochem. J. 192 (1980) 613. (ch. III)

Munro, H.N., Waddington, S. \& Begg, D.J.: Effect of protein intake on ribonucleic acid metabolism in liver cell nuclei of the rat. J. Nutr. 85 (1965) 319. (ch. I)

Murphy, E.A.: Genetics of longevity in man. In: The genetics of ageing (Schneider, E.L., ed.). Plenum Press, New York (1977). (ch. 1)

Nahon, J.L., Gal, A., Frain, M., Sell, S. E Sala-Trepat, J.M.: No evidence for post-transcriptional control of albumin and $\alpha$-fetoprotein gene expression in developing rat liver and neoplasia. Nucl. Ac. Res. 10 (1982) 1895. (ch. 1) 
Obenrader, M., Chen, J., Ove, P. E Lansing, A.1.: Etiology of increased albumin synthesis in old rats. Exp. Gerontol. 9 (1974a) 173. (ch. $\| I I$ \& VI)

Obenrader, M., Chen, J., Ove, P. E Lansing. A.1.: Functional regeneration in liver of old rats after partial hepatectomy. Exp. Gerontol. 9 (1974b) 181. (ch. I)

Oratz, M., Rothschild, M.A. \& Schreiber, S.S.: Alcohol, amino-acids and albumin synthesis. 11. Alcohol inhibition of albumin synthesis reversed by arginine and spermine. Gastroenterology 71 (1976) 123. (ch. 1)

Oratz, M., Rotschild, M.A. \& Schreiber, S.S.: Spermine stimulation of $\mathrm{CCl}_{4}$ depressed protein synthesis in rabbits. Gastroenterology 79 (1980) 165. (ch. I)

Oratz, M., Rotschild, M.A., Schreiber, S.S., Burks, A., Mongelli, J. $\&$ Matarese, B.: The role of the urea cycle and polyamines in albumin synthesis. Hepatology 3 (1983) 567 . (ch. i)

Orgel, L.E.: The maintenance of the accuracy of protein synthesis and its relevance to aging. Proc. Natl. Acad. Sci. USA 49 (1963) 517. (ch. 1)

Orgel, L.E.: Aging of clones of mammalian cells. Nature 243 (1973) 441. (ch. I)

Ove, P., Obenrader, M. \& Lansing, A." Synthesis and degradation of liver proteins in young and old rats. Biochim. Biophys. Acta 277 (1972) 211. (ch. I, 11, IV \& VII)

Pain, V.M., Clemens, M.J. \& Garlick, P.J.: The effect of dietary protein deficiency on albumin synthesis and on the concentration of active albumin messenger ribonucleic acid in rat liver. Biochem. J. 172 (1978) 129. (ch. 1)

Pennial, R., Baker, M., Holbrook, J.P. \& Viskup, R.W.: Age-associated changes in rat hepatocytes: studies of the character of a polypeptide subject to diminished synthesis at an early age. Age 4 (1981) 9. (ch. 1)

Peters. T.: The biosynthesis of rat serum albumin. 111. Amino acid composition of rat albumin. 1. Biol. Chem. 237 (1962) 2182. (ch. 1) 
Peters, T. \& Reed, R.C.: The biosynthesis of rat serum albumin. Composition and properties of the intracellular precursor, proalbumin. J. Biol. Chem. 255 (1980) 3156. (ch. 1)

Pickart, L.: Increased ratio of plasma free fatty acids to albumin during normal aging and in patients with coronary heart disease. Atherosclerosis 46 (1983) 21. (ch. VII)

Pratten, M.K., Duncan, R. \& Lloyd, J.B.: Absorptive and passive pinocytic uptake. In: Coated vesicles (Ockleford, C.D. \& Whyte, A., eds.) Cambridge University Press, Cambridge (1980) 179. (ch. III)

Princen, H.M.G., Mol-Backx, G.P.B.M. E Yap, S.H.: Acute effects of ethanol intake on albumin and total protein synthesis in free and membrane-bound polyribosomes of rat liver. Biochim. Biophys. Acta 655 (1981) 119. (ch. \& \& IV)

Princen, H.M.C., Selten, G.C.M., Selten-Versteegen, A.E., MolBackx, G.P.B.M., Nieuwenhuizen, W. \& Yap, S.H.: Distribution of mRNAs of fibrinogen polypeptides and albumin in free and membranebound polyribosomes and induction of a-fetoprotein mRNA synthesis during liver regeneration after partial hepatectomy. Biochim. Biophys. Acta 699 (19B2) 121. (ch. 1)

Princen, H.M.G., Mol-Backx, G.P.B.M. \& Yap, S.H.: Restoration effects of glucose refeeding on reduced synthesis of albumin and total protein and on disaggregated polyribosomes in liver of starved rats: Evidence of a post-transcriptional control mechanism. Ann. Nutr. Metab. 27 (1983) 182. (ch. I)

Quin, R.P., Price, G.B., Ellis, J.M. \& Makinodan, T.: Catabolic halflives of immunoglobulin and albumin as a function of age in mice. $J$. Gerontol. 28 (1973) 257. (ch. 11)

Quinn, P.S., Gamnle, M. \& Judah, J.D.: Biosynthesis of serum albumin in rat liver. Biochem. J. 146 (1975) 389. (ch. I)

Radl, J., Skvaril, F., Masopust, J. \& Kithier, K.: Quantitative estimation of human immunoglobublins. 11. The development of serum immunoglobulin levels in man. J. Hyg. Epidem. Microbiol. Immun. 14 (1970) 488. (ch. II, III, VI) 
Ramsey, J.C. E Steel, W.J.: Effect of starvation on the distribution of free and membrane-bound ribosomes in rat liver and on the content of phospholipid and glycogen in purified ribosomes. Biochim. Biophys. Acta 447 (1976) 312. (ch. I, IV \& VII)

Redman, C.M., Banerjee, D., Manning, C., Huang, C.Y. \& Green, K.: In vivo effect of colchicine on hepatic protein synthesis and on the conversion of proalbumin to serum albumin. 1 . Cell Biol. 77 (1978) 400. (ch. 1)

Reznick, A.Z., Lavie, L., Gershon, H.E. E Gershon, D.: Age-associated accumulation of altered FDP aldolase $B$ in mice. Conditions of detection and determination of aldolase half-life in young and old animals. FEBS Letters 128 (1981) 221. (ch. 1)

Richardson, A.: The relationship between aging and protein synthesis. In: Handbook of Biochemistry in Aging (Florini, J.R., ed.) CRC Press, Boca Raton, Florida (1981) 79. (ch. I, IV \& VII)

Richardson, A., Sparks, M.B., Staecker, J.L., Hardwick, J.P. \& Liu, D.S.H.: The transcription of various types of ribonucleic acids by hepatocytes isolated from rats of various ages. J. Gerontol. 37 (1982) 666. (ch. 1)

Richardson, A. \& Birchenall-Sparks, M.C.: Age-related changes in protein synthesis. In: Review of Biological Research in Aging, vol. 1 (Rothstein, M., ed.) Alan R. Liss, New York (1983) 255. (ch. I, IV \& VII)

Richardson, A., Rutherford, M.S., Birchenall-Sparks, M.C., Roberts. M.S., Wu, W.T. \& Cheung, H.T.: Levels of specific messenger RNA species as a function of age. Aging 29 (1985) 229. (ch. I \& IV]

Richter, $V .:$ Turnover of lipogenic enzymes of rat liver in dependence on age. Acta Biol. Med. Germ. 36 (1977) 1833. (ch. I)

Rigby, P.W.J., Diechmann, M., Rhodes, C. $\varepsilon$ Berg, P.: Labelling deoxyribonucleic acid to high specific activity in vitro by nick translation with DNA polymerase I. J. Mol. Biol. 113 (1977) 237. (ch. V) 
Roberts, B.E. \& Patterson, B.M.: Efficient translation of tabacco mosaic virus RNA and rabbit 95 globin RNA in a cell free system from commerciall wheat germ. Proc. Natl. Acad. Sci. USA 70 (1973) 2330. (ch. IV)

Roberts, A.V.S., Williams, K.E. \& Lloyd, J.B.: The pinocytosis of 125 -labelled poly(vinylpyrrolidone), $\left({ }^{14} \mathrm{C}\right)$-sucrose and $\left({ }^{198} \mathrm{~A}\right)$-gold by the yolk sac of the rat. Biochem. J. 168 (1977) 239. (ch. III)

Robinson, A.B., Mckerrow, J.H. \& Cary, P.: Controlled deamidation of peptides and proteins. An experimental hazard and a possible biological timer. Proc. Natl. Acad. Sci. USA 66 (1970) 753. (ch. 1)

Rothschild, M.A., Bauman, A., Yalow, R.S. $\varepsilon$ Berson, S.A.: The effect of large doses of desiccated thyroid on the distribution and metabolism of albumin 131 , in euthyroid subjects. J. Clin. Invest. 36 (1957) 422. (ch. 1)

Rothschild, M.A., Oratz, M. \& Schreiber, S.S.: Albumin synthesis (first of two parts). N. Eng. J. Med. 286 (1972) 748. (ch. 1)

Rothschild, M.A., Oratz, M. \& Schreiber, S.S.: Alcohol, amino acids and albumin synthesis. Gastroenterology 67 (1974) 1200. (ch. I)

Roy, A.K. \& Dowbenko, D.J.: Role of growth hormone in the multihormonal regulation of messenger RNA for $\alpha_{2 u}$-globulin in the liver of hypophysectomized rats. Biochemistry 16 (1977) 3918. (ch. 1)

Rubin, E. \& Lieber, C.S.: Alcohol induced hepatic injury in non-alcoholic volunteers. N. Eng. J. Med. 278 (1968) 869. (ch. 1)

Russell, J.H. \& Greller, D.M.: The structure of rat proalbumin. J. Biol. Chem. 250 (1975) 3409. (ch. 1)

Sala-Trepat, J.M., Savage, M.J. E Bonner, J.: Isolation and characterization of poly(adenylic acid)-containing messenger ribonucleic acid from rat liver polysomes. Biochim. Biophys. Acta 519 (1978) 173. (ch. V)

Sala-Trepat, J.M., Dever, J., Sargent, T.D., Thomas, K., Sell, S. $\varepsilon$ Bonner, J.: Changes in the expression of albumin and $\alpha$-fetoprotein genes during rat liver development and neoplasia. Biochemistry 18 (1979) 2167. (ch. I) 
Salatka, K. Kresge, D., Harris, L.Jr., Edelstein, D. \& Ove, P.: Rat serum protein changes with age. Exp. Gerontol. 6 (1971) 25. (ch. II, IV \& VII)

Samis, H.V.S., Wulf, V.J. \& Falzone, J.A.: The incorporation of $\left({ }^{3} \mathrm{H}\right)$-cytidine into ribonucleic acid of liver nuclei of young and old rats. Biochim. Biophys. Acta 91 (1964) 223. (ch. 1)

Sargent, T.D., Wu, J-R., Sala-Trepat, J.M., Wallace, R.B., Reyes, A.A. \& Bonner, J.: The rat serum albumin gene: Analysis of cloned sequences. Proc. Natl. Acad. Sci. USA 76 (1979) 3256. (ch. I) Sargent, T.D., Yang, M. \& Bonner, I.: Nucleotide sequence of cloned rat serum albumin messenger RNA. Proc. Natl. Acad. Sci. USA 78 (1981a) 243. (ch. I)

Sargent, T.D., Jagodzinski, L.J., Yang, M. \& Bonner, J.: Fine structure and evolution of the rat serum albumin gene. Mol. Cell. Biol. 1 (1981b) 871. (ch. 1)

Sato, A., Noda, K. \& Natari, Y.: The effect of protein depletion on the rate of protein synthesis in rat liver. Biochim. Biophys. Acta 564 (1974) 475. (ch. I)

Shmookler Reis, R.J.: Ribosomes from aging mice are not generally deficient in cell-free protein synthesis. Mech. Ageing Dev. 17 (1981) 311. (ch. I \& VII)

Sidransky, H., Verney, E. \& Murty, C.N.: Effect of spermine on hepatic polyribosomes and protein synthesis in rats. Biochem. Med. 27 (198:2) 68. (ch. 1)

Snedecor, G.W. E Cochran, W.G.: Statistical Methods, 7th ed. lowa State University Press, Ames, USA (1980). (ch. VI)

Sobel, H. \& Bowman, R.: Protein metabolism in aging mice. J. Gerontol. 26 (1971) 558. (ch. I)

Soreq, H., Nudel, U., Salomon, R., Revel, M. \& Littauer, U.Z.: In vitro translation of polyadenylic acid-free rabbit globin messenger RNA. J. Mol. Biol. 88 (1974) 233. (ch. Vll)

Steinfeld, J.L., Paton, R.R., Flick, A.L., Milch, R.A. E Beach, F.E.: Mechanism of hypoproteinemia in patients with regional enteritis and ulcerative colitis. Am. J. Med. 29 [1960) 405. (ch. IIl) 
Sterling, K.: The turnover rate of serum albumin in man as measured by $1^{131}$-tagged albumin. J. Clin. Invest. 30 (1951) 1228. (ch. I)

Strair, R.K., Yap, S.H. \& Shafritz, D.A.: Use of molecular hybridization to purify and analyze albumin mRNA from rat liver. Proc. Natl. Acad. Sci. USA 74 (1977) 4346. (ch. I \& IV)

Strauss, A.W., Donohue, A.M., Bennett, C.D., Rodkey, J.A. \& Alberts, A.W.: Rat liver preproalbumin: in vitro synthes is and partial amino acid sequence. Proc. Natl. Acad. Sci. USA 74 (1977) 1358. (ch. 1)

Strehler, B.L.: Origin and comparison of the effects of time and highenergy radiation on living systems. Q. Rev. Biol. 34 (1959) 117. (ch. I)

Strehler, B.L., Hirsch, G., Gussek, D., Johnson, R. \& Bick. M.: Codon-restriction theory of aging and development. J. Theor. Biol. 33 (1971) 429. (ch. I)

Strohman, R.C., Moss, P.S., Micou-Eastwood, J., Przybyla, A. E Paterson, B.: Messenger RNA for myosin polypeptides. Isolation from single myogenic cell cultures. Cell 10 (1977) 265. (ch. IV)

Szillard, L.: On the nature of the aging process. Proc. Natl. Acad. Sci. USA 45 (1959) 30. (ch. 1)

Taylor, J.M. \& Schimke, R.T.: Synthesis of rat liver albumin in a rabbit reticulocyte cell-free protein-synthesizing system. J. Biol. Chem. 248 (1973) 7661. (ch. IV \& VI)

Taylor, J.M. \& Tse, T.P.H.: Isolation of rat albumin messenger RNA. J. Biol. Chem. 251 (1976) 7461 " (ch. I)

Thomas, P.S.: Hybridization of denatured RNA and small DNA fragments transferred to nitrocellulose. Proc. Natl. Acad. Sci. USA 77 (1980) 5201. (ch. V)

Tilghman, S.M. \& Belayew, A.: Transcriptional control of the murine albumin/a-fetoprotein locus during development. Proc. Natl. Acad. Sci. USA 79 (1982) 5254. (ch. 1)

Topal, M.D. \& Fresco, J.R.: Base pairing and fidelity in codon-anticodon interaction. Nature 263 (1978) 289. (ch. I) 
Urban, J., Inglis, A.S., Edwards, K. \& Schreiber, G.: Chemical evidence for the difference between albumins from microsomes and serum and a possible precursor-product relationship. Blochem. Biophys. Res. Commun. 61 (1974) 494. (ch. 1)

Van Bezonijen, C.F.A., Grell, T. $\varepsilon$ Knook, D.L.: Albumin synthesis by liver parenchymal cells from young, adult and old rats. Biophys. Biochem. Res. Commun. 71 (1976) 513. (ch. I, IV \& Vill)

Van Bezooijen, C.F.A., Grell, T. $\varepsilon$ Knook, D.L.: The effect of age on protein synthesis by isolated liver parenchymal cells. Mech. Ageing Dev. 6 (1977) 293. (ch. I)

Van Bezooijen, C.F.A. \& Knook, D.L.: Aging changes in bromsulfophthalein uptake, albumin and total protein synthesis in isolated hepatocytes. In: Liver and Ageing [Platt, D., ed.] Schattauer Verlag. Stuttgart, New York (1977) 227. (ch. I, IV \& VII)

Van Bezooijen, C.F.A., Sakkee, A.N. \& Knook, D.L.: Sex and strain dependency of age-related changes in protein synthesis of isolated rat hepatocytes. Mech. Ageing Dev. 17 (1981) 11. (ch. 1)

Vandenhaute, G., Claes-Reckinger, N. \& Delcour, J.: Age-related functional alteration of mouse liver ribosomes. Exp. Gerontol. 18 (1983) 355. (ch. I)

Van Tongeren, J.H.M., Reichert, W.J. \& Kamphuys, T.M.: Demonstration of protein-llosing gastroenteropathy. The quantitative estimation of gastrointestinal protein loss, using ${ }^{51} \mathrm{Cr}$-labelled plasma proteins. Clin. Chim. Acta 14 (1966) 42. (ch. III)

Van Tongeren, J.H.M.: Eiwitverlies via de darmwand. Thesis. University van Nijmegen. (1967). (ch. III)

Venkatesan, N. \& Steele, W.J.: Free and membrane-bound polysomes of rat liver: separation in nearly quantitative yield and analysis of structure and function. Biochim. Biophys. Acta 287 [1972] 526 . (ch. IV)

Viskup, R.W., Baker, M., Holbrook, J.P. E Penniall, R.: Age-associated changes in activities of rat hepatocytes. 1. Protein synthesis. Exp. Aging Res. 5 (1979) 487. (ch. I) 
Viskup, R.W., Holbrook, J.P., Baker, M. \& Penniall, R.: Age-associated changes in rat hepatocytes: An early decline in synthesis of a specific protein by endoplasmic reticulum. Age 4 (1981) 19. (ch. 1)

Walford, R.L.: The Immunologic Theory of Aging. Williams and Wilkins, Baltimore (1969). (ch. 1)

Webster, G.C. Webster, S.L.: Decreased synthesis of elongation factor 1 $(E F-1)$ : An early event in the age-related reduction in protein synthesis. Fed. Proc. 41 (1982) 383. (ch. I)

Weisiger, R., Gollan, J. \& Ockner, R.: Receptor for albumin on the liver cell surface may mediate uptake of fatty acids and other albumin-bound substances. Science 211 (1981) 1048. (ch. 1)

Wiederanders, B.: Die Bestimmung der Umsatzgeschwindigkeit von Leberproteinen sehr alter Ratten. Z. Altersforsch. 36 (1981) 373. (ch. I) Willson. P.D.: Enzyme patterns in young and ald mouse liver and lungs. Gerontologia 18 (1972) 36. (ch. I)

Wilson, P.D.: Enzyme levels in animals of various ages. In: Handbook of Biochemistry in Aging. (Florini, J.R., ed.). CRC Press, Boca Raton, Florida (1981) 163. (ch. 1)

Wilson, P.D. \&. Franks, L.M.: Enzyme patterns in young and old mouse kidneys. Gerontologia 17 (1971) 16. (ch. 1)

Wisniewski, H.M. \& Terry, R.D.: Morphology of the aging brain, human and animal. Progress in Brain Research 40 (1973) 167. [ch. 1)

Wochner, R.D., Weissman, S.M. ,Waldmann, T.A. "Houston, D. \& Berlin, N.I.: Direct measurement of the rates of synthesis of plasma protein in control subjects and patients with gastrointestinal protein loss. J. Clin. Invest. 47 (1968) 971. (ch. III)

Yap, S.H., Strair, R.K. \& Shafritz, D.A.: Distribution of rat liver albumin mRNA in membrane-bound and free polysomes as determined by molecular hybridization. Proc. Natl. Acad. Scï. USA 74 (1977) 5397. (ch. 1) 
Yap. S.H., Strair, R.K. E Shafritz, D.A.: Effect of a short term fast on the distribution of cytoplasmic albumin messenger ribonucleic acid in rat liver. Evidence for formation of free albumin messenger ribonucleoprotein particles. J. Biol. Chem. 253 (1978) 4944. (ch. 1) Yedgar, S., Carew, T.E., Pittman, R.C., Beltz, W.F. \& Steinberg, D.: Tissue sites of catabolism of albumin in rabbits. Am. J. Physiol. 244 (1983) 101. (ch. III)

Yousef, M.K. \& Johnson, H.D.: ${ }^{75}$ Se-selenomethionine turnover rate during growth and aging in rats. Proc. Soc. Exp. Biol. Med. 133 (1970) 1351. (ch. I)

Yu, S. \& Redman, C.M.: In vitro synthesis of rat premproalbumin. Biochem. Biophys. Res. Commun. 76 (1977) 469. (ch. 1)

Zern, M.A., Chakrabórty, P.R., Ruiz-Opazo, N., Yap, S.H. E Shafritz, D.A.: Development and use of a rat albumin cDNA clone to evaluate the effect of chronic ethanol administration on hepatic protein synthesis. Hepatology 3 (1983) 317. (ch. V).

Zurcher, C., Van Zwieten, M.J., Solleveld, H.A. \& Hollander, C.F.: Aging research. In: The mouse in biomedical research. vol. IV. Academic Press, New York (1982) 11, (ch. 1) 

It requires the cooperation and support of a number of people to plan and perform a research project and to transform the results obtained into a monograph. It is impossible to thank everyone individually who contributed in any way to this work, but, nonetheless, without their support this monograph would never have come into being.

I would like to express my special gratitude to:

- Dr. C.F.A. van Bezooijen for his continuing support, his stimulating criticism during the investigations and for his ability to share his room and to discuss social and scientific problems with a person that is as headstrong as 1 am.

- Dr. S.H. Yap for giving me the opportunity to do a part of my investigations in the Division for Gastrointestinal and Liver Diseases, Department of Medicine, University of Nijmegen, for his valuable contribution to the experimental work and for fruitful discussions.

- Prof.Dr. C.F. Hollander for his valuable suggestions during the preparation of this monograph.

- Prof.Dr. D.L. Knook for introducing me not only to the field of the liver and aging but also to the field of gastronomy and art.

- Dr. H.M.G. Princen for introducing me to the ficld of RNA, for providing me with a RNase-neurosis and for his friendship.

- Mr. R.E.W. van Leeuwen and Mrs. J. van Haarlem for their participation in the investigations as a student.

- Mrs. M. van der Kroef-Goudzwaard and Mr. H. van der Boom for their expert technical assistance.

- Dr. M.A. Horan for finding the time to edit the English text whilc writing his own thesis, for his valuable comments on the contents of the thesis.

- Drs. A. Brouwer for his enthusiasm and his ability to find an answer to all my questions even to the ones that have not yet been asked. 
- Dr. A.M. de Leeuw for showing me things, both scientific and social, with a higher resolution and for making congress visits always surprising.

- Dr. S. Durham for performing the histology for me.

- Mrs. M. van Heyenoort-Roggenkamp and Mrs. A.M. Meinen ("Mupke" and "Musjke") for carefully typing the manuscript and preparing the camera-ready copy and for their calm even in my greatest moments of despair.

- Mr. A.A. Glaudemans for preparing graphs and figures and for excellent photographic work.

Last, but certainly not least, I want to express my special gratitude to Ellen Roskes, who in all the years of my study never failed to encourage me and to believe in me. Without her unselfish support \& would never have been able to finish this thesis.

These investigations were supported in part by the Foundation for Medical Research (FUNCO) which is subsidized by the Netherlands Organization for Advancement of Pure Research ( $Z W O$ ). 
Geboren op 18 mei 1957 te Heerlen. Na het behalen van het diploma Gymnasium B in 1975 aan het St. Michiel Lyceum te Geleen werd aangevangen met de studie Scheikunde aan de Rijksuniversiteit te Leiden. Het kandidaatsexamen (S2) werd afgelegd in januari 1979. Het doctoraalexamen werd afgelegd in december 1981 met als hoofdrak Biochemie o.l.v. Prof.Dr. L. Bosch. Bijvakken waren Farmacologie o.l.v. Prof.Dr. D.D. Breimer en Organische Synthese o.l.v. Prof.Dr. A. van der Gen.

Van november 1981 tot november 1985 werkzaam op het Instituut voor Experimentele Gerontologie van de Gezondheidsorganisatie TNO op FUNGO-basis, alwaar het onderzoek dat ten grondslag ligt aan dit proefschrift onder leiding van Dr. C.F.A. van Bezooijen en Dr. S.H. Yap (afd. maag-, darm- en leverziekten van het St. Radboud Ziekenhuis te Nijmegen) werd uitgevoerd. Sinds november 1985 als wetenschappelijk medewerker verbonden aan het Instituut voor Experimentele Gerontologie TNO, met als taakomschrijving het onderzoek naar de invloed van veroudering op het cytochroom $\mathrm{P}-450$ systeem in de lever. 